\author{
UNIVERSIDADE DE SÃO PAULO \\ FACULDADE DE CIÊNCIAS FARMACÊUTICAS \\ Programa de Pós-Graduação em Toxicologia e Análises \\ Toxicológicas
}

\title{
Análogos de micosporinas: síntese e avaliação de parâmetros farmacológicos e toxicológicos
}

Daniel Andreguetti

Dissertação para obtenção do grau de

MESTRE

Orientador:

Prof. Dr. Pio Colepicolo Neto

São Paulo

2010 
Daniel Andreguetti

\title{
Análogos de micosporinas: síntese e avaliação de parâmetros farmacológicos e toxicológicos
}

\author{
Comissão Julgadora
}

da

Dissertação para obtenção do grau de Mestre

\author{
Prof. Dr. Pio Colepicolo Neto \\ orientador/presidente
}

$1^{\circ}$. examinador

$2^{\circ}$. examinador

São Paulo, de de 2010. 


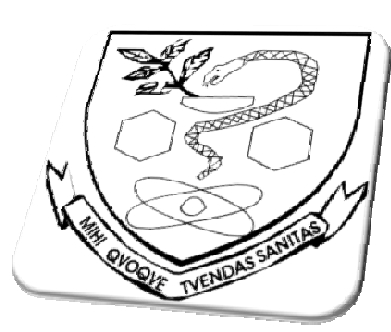

\section{UNIVERSIDADE DE SÃO PAULO}

FACULDADE DE CIÊNCIAS FARMACÊUTICAS DEPARTAMENTO DE ANÁLISES CLÍNICAS E TOXICOLÓGICAS

PROGRAMA DE TOXICOLOGIA E ANÁLISES TOXICOLÓGICAS

Análogos de micosporinas: síntese e avaliação de parâmetros farmacológicos e toxicológicos

\section{DANIEL ANDREGUETTI}

Orientador

Prof. Dr. Pio Colepicolo Neto

São Paulo, 2010 
"Crever watk on the traveled path,

because it only leads pou where the others have been"

Alesander Graham \$ell 
Aos meus pais, Pedro e Tânia, e meus irmãos, Diego e Pablo, pelo amor e apoio, por terem aceitado a distância e pela contribuição que incondicionalmente tiveram sobre a minha vida.

À minha namorada Thaísa Sandini pelo amor, companheirismo e compreensão nos momentos difíceis passados durante esses anos.

Ao prof. Dr. Pio Colepicolo pela amizade, confiança e orientação, e pelos conhecimentos que possibilitaram meu crescimento pessoal e profissional. 


\section{Agradecimentos}

Ao professor Pio Colepicolo pela amizade, apoio e orientação.

Ao professor Ernani Pinto pela amizade e incentivo.

Ao professor Mauricio Yonamine pela amizade e confiança.

À professora Sandra Macedo da URI-Erechim pela confiança e por mostrar caminhos importantes.

À FAPESP e à Capes pela concessão do aporte financeiro.

À professora Ana Campa e seus alunos Fabíola e Edson pela colaboração.

Aos professores Sidnei Moura e Claudio Pereira pela cooperação e amizade.

Ao programa de Toxicologia e Análises Toxicológicas, à Faculdade de Ciências Farmacêuticas e à Universidade de São Paulo.

Aos professores Diogo Silva, Ana Paula Loureiro e Leandro Helguera pelas sugestões feitas no exame de qualificação.

Aos funcionários Ângelo, Luzia e Dalva da toxicologia e a Sandra da química. 
Aos colegas de laboratório Aline, Angela, Camila, Cícero, Dina, Diego, Ed, Eliezer, Érika, Fabi, Felipe, João, Leonardo, Luis, Luiza, Paula, Renato e Vanessa.

Aos colegas da toxicologia Amanda, Ana Lúcia, Ana Marcela, André Fukushima, Ariane, Bárbara, Beatriz, Bruna, Camila, Carine, Cristina, Cyro, Daniela, Fabyana, Felipe, Graziela, Lara, Larissa, Mariah, Marli, Natália, Raphael, Rodrigo, Ronaldo, Simone Santana, Simone, Stella, Tiago, Vânia.

Aos amigos do Solar Alberto, Alex, André Ribeiro, André Valle, Enio, Fabriciano, George, Helder, Henrique, Mauricio, Rafael Menck, Rafael Zanetti, Ricardo, Rodrigo, Thiago Barcelos, Thomas, Tiago Peixe.

A todas as pessoas que não foram citadas aqui, mas de alguma forma tiveram sua parcela de contribuição durante esse tempo. 


\section{Resumo}

ANDREGUETTI, D. X. Análogos de micosporinas: síntese e avaliação de parâmetros farmacológicos e toxicológicos. 2010. Dissertação de Mestrado Departamento de Análises Clínicas e Toxicológicas, Faculdade de Ciências Farmacêuticas, Universidade de São Paulo, 2010.

Micosporinas são substâncias pertencentes a um grupo de compostos naturalmente encontrados em algas e fungos, que são utilizadas por estes organismos como mecanismo de defesa. São potentes bloqueadores químicos de radiação ultravioleta (UV), atuando principalmente na faixa espectral da radiação UVA, com absorção máxima variando entre 300 e $360 \mathrm{~nm}$, dependendo de sua composição estrutural. Quimicamente, são caracterizadas por um cromóforo ciclohexenona ou ciclohexenimina conjugado com o nitrogênio substituinte de um aminoácido ou aminoálcool. Em alguns membros deste grupo também foi evidenciada uma moderada atividade antioxidante, podendo estes atuarem como antioxidantes naturais em organismos marinhos.

Os processos sintéticos utilizados, com o objetivo de obtenção de forma não natural destas moléculas, se basearam em princípios de química verde e evitaram a utilização de solventes orgânicos bem como a produção de intermediários tóxicos. As reações envolvendo uma dicetona cíclica e diferentes aminoácidos foram testadas por diferentes metodologias "verdes". A partir destes processos foram obtidos 11 análogos das micosporinas, dos quais 9 tiveram seus potenciais farmacológicos e toxicológicos avaliados.

Para verificação do potencial farmacológico das moléculas, foi determinado um espectro de absorção de radiação ultravioleta para cada um dos compostos, que posteriormente tiveram seus potenciais antioxidantes verificados 
através das atividades sequestrantes de radicais DPPH e de radical superóxido. Os espectros obtidos dos compostos demonstram uma absorção máxima variando de 255 a $309 \mathrm{~nm}$ para os diferentes compostos. No ensaio antioxidante de DPPH, dois compostos atingiram a IC $\mathrm{C}_{50}$, em concentrações de 1,597 e 1,387 mM, e no ensaio de sequestro de radical superóxido, todos os compostos testados atingiram a IC $C_{50}$, em concentrações que variam de 0,204 a 1,164 mM. O potencial citotóxico das moléculas foi testado em culturas celulares de fibroblastos 3T3, através da incorporação das substâncias em diferentes concentrações e verificação de viabilidade celular, pelo método de redução de MTT, após exposição por 24 horas. O ensaio fototóxico procedeu da mesma forma, porém com a exposição das células a radiação ultravioleta concomitantemente à aplicação dos compostos. Os resultados obtidos demonstraram que nenhum dos compostos pode ser considerado citotóxico, porém um dos compostos é ativado com a exposição a radiação UVA, sendo assim, considerado fototóxico.

Palavras chave: Micosporinas. Química verde. Antioxidante. Citotoxicidade. Fototoxicidade. 


\begin{abstract}
ANDREGUETTI, D. X. Mycosporines analogues: synthesis and evaluation of pharmacological and toxicological parameters. 2010. Dissertação de Mestrado Departamento de Análises Clínicas e Toxicológicas, Faculdade de Ciências Farmacêuticas, Universidade de São Paulo, 2010.
\end{abstract}

Mycosporines are substances belonging to a group of compounds naturally found in algae and fungi, which are used by these organisms as a defense mechanism. They are potent chemical blockers of ultraviolet radiation (UV), acting mainly in the spectral range of UVA, with maximum absorption ranging from 300 to $360 \mathrm{~nm}$, depending on its structural composition. Chemically, they are characterized by a cyclohexenone or cyclohexenimine chromophore conjugated with the nitrogen substituent of an amino acid or an amino alcohol. Some mycosporines present a moderate antioxidant activity; in this case, they can act as natural antioxidants in marine organisms.

Our synthesis was based on green chemistry principles and avoided the use of organic solvents and the production of toxic intermediates. The reactions involving a cyclic diketone and different amino acids were tested by different clean methods. Eleven mycosporines analogues were obtained. Nine of them had their pharmacological and toxicological potential evaluated.

In order to verify the pharmacological potential of molecules, we determined the UV absorption spectrum of each mycosporine analogue. In addition, we evaluated their antioxidant activity by DPPH and superoxide radical scavenging potential methods. The compounds spectra show an absorption maximum ranging from 255 to $309 \mathrm{~nm}$ for different compounds. In the DPPH assay, two compounds reached the $\mathrm{IC}_{50}$ at concentrations of 1.597 e $1.387 \mathrm{mM}$. 
In the superoxide scavenging assay, all compounds tested reached the $\mathrm{IC}_{50}$ at concentrations ranging from 0.204 to $1.164 \mathrm{mM}$. The cytotoxic potential of these molecules was tested in cell cultures (3T3 fibroblasts) through the incorporation of different concentrations of the analogues and checking cell viability by MTT reduction method. The phototoxic test was conducted similarly, but adding the exposure of cells to UV radiation after addition of mycosporines analogues. The results showed that none of the compounds can be considered cytotoxic, but one of the compounds is activated by exposure to UVA radiation, becoming phototoxic.

Key Words: Mycosporines. Green chemistry. Antioxidant. Cytotoxicity. Phototoxicity. 


\section{LISTA DE ABREVIATURAS E SIGLAS}

- Irr - Sem incidência de radiação

+ Irr - Com incidência de radiação

4DG - 4-deoxigadusol

Abs - Absorbância

ACN - Acetonitrila

AM-4-n-Phe - ácido 2-(4-nitrofenil)-2-(3-oxociclohexilideneamino) acético

AM-Arg - ácido 5-guanidino-2-(3-oxociclohexilideneamino) pentanóico

AM-Car - ácido 3-(1H-imidazol-5-il)-2-(3-(3-oxociclohexilideneamino)propanamido) propanóico

AM-Glu - ácido 2-(3-oxociclohexilideneamino) pentanodióico

AM-His - ácido 3-(1H-imidazol-4-il)-2-(3-oxociclohexilideneamino)propanóico

AM-Nle - ácido 2-(3-oxociclohexilideneamino) hexanóico

AM-Ser - ácido 3-hidroxi-2-(3-oxociclohexilideneamino) propanóico

AM-Trp - ácido 3-(1H-indol-3-il)-2-(3-oxociclohexilideneamino) propanóico

AM-Tyr - ácido 2-(4-hidroxifenil)-2-(3-oxociclohexilideneamino) acético

$\mathrm{CD}_{3} \mathrm{OD}$ - Metanol deuterado

$\mathrm{C}_{\text {máx }}$ - Concentração máxima

$\mathrm{CPZ}$ - Clorpromazina

$\mathrm{D}_{2} \mathrm{O}$ - Água deuterada

DMEM - Dulbecco's Modified Eagle's Medium

DMSO - Dimetilsulfóxido

DPPH - 2,2-difenil-1-picrilhidrazila

ERO - Espécie reativa de oxigênio

$\mathrm{Et}_{2} \mathrm{O}$ - Éter etílico

FDA - Food and Drugs Administration

FS - Fase sólida

HPLC - Cromatografia líquida de alta eficiência

$\mathrm{IC}_{50}$ - Concentração inibitória de $50 \%$

IV - Radiação infravermelha

J- Joule

m/z - Razão massa carga

MAA - Aminoácido tipo micosporina

mAU - Unidade de absorção

$\mathrm{MeOH}-$ Metanol

$\mathrm{MHz}$ - Megahertz

Milli-Q - Água deionizada purificada pelo sistema Millipore

MO - Microondas

MTT - Brometo de [3-(4,5-dimetiltiazol-2-il)-2,5-difeniltetrazólio] 
NADH - Nicotinamida adenina dinucleotideo reduzido

NBT - Tetrazólio nitroazul

OECD - Organisation for Economic Co-operation and Development

PAR - Radiação fotossinteticamente ativa

PBS - Tampão fosfato salina

PDA - Detector de arranjo de fotodiodos

PIF - Fator de fotoirritação

PMS - Metassulfato de fenazina

ppm - Partes por milhão

RMN - Ressonância magnética nuclear

RMN ${ }^{13} \mathrm{C}$ - Ressonância magnética nuc lear de carbono

RMN ${ }^{1} \mathrm{H}$ - Ressonância magnética nuclear de hidrogênio

$\mathrm{SiO}_{2}-$ Sílica

US - Ultrassom

UV - Ultravioleta

Vis - Radiação visível

W- watt

$\delta$ - Deslocamento químico

$\varepsilon$ - Coeficiente de extinção molar

$\pi$ HOMO - Orbital molecular preenchido de maior energia

$\pi^{*}$ LUMO - Orbital molecular vazio de menor energia 


\section{SUMÁRIO}

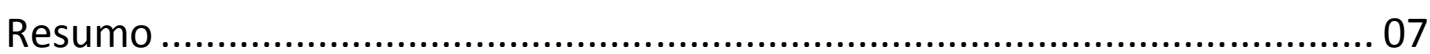

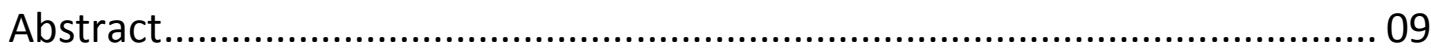

Lista de Abreviaturas e Siglas ............................................................. 11

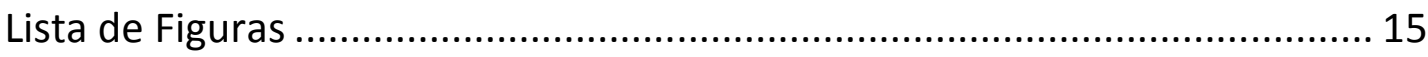

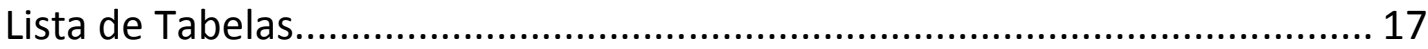

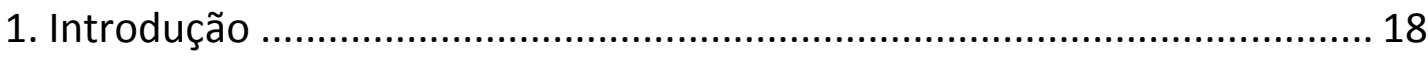

1.1 Radiação Ultravioleta..................................................................... 19

1.1.1 Tipos de filtros solares e mecanismos de ação .............................. 22

1.1.2 Estresse oxidativo por UVR ................................................... 24

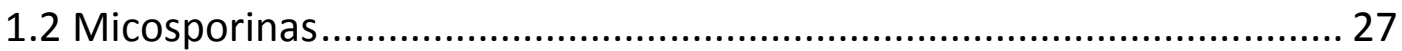

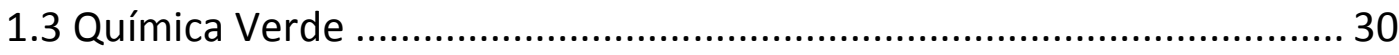

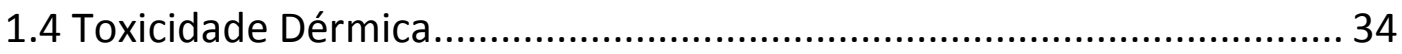

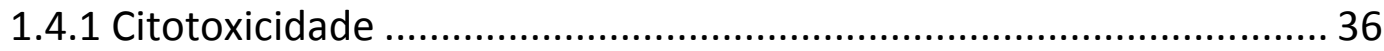

1.4.2 Fototoxicidade ................................................................ 38

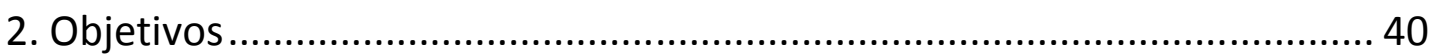

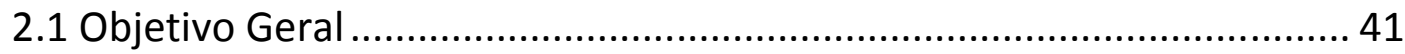

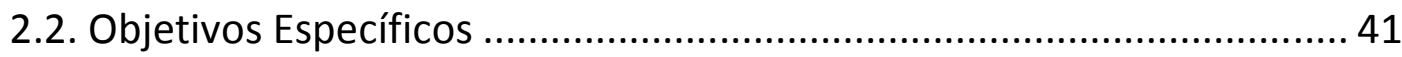

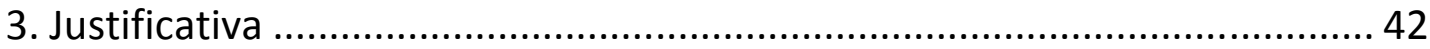

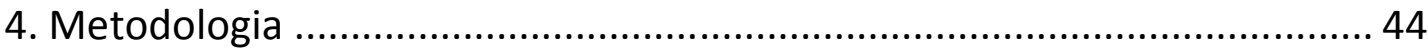

4.1 Síntese dos Análogos de Micosporinas ............................................ 45

4.1.1 Padronização de métodos sintéticos limpos ................................. 45

4.1.2 Síntese dos compostos ....................................................... 48

4.1.3 Caracterização dos compostos ..................................................... 52

4.2 Propriedades das Moléculas ....................................................... 52

4.2.1 Determinação do espectro de absorção de UV ...............................5 53 
4.2.2 Determinação do Coeficiente de Extinção Molar ............................. 53

4.2.3 Determinação de potencial antioxidante ....................................... 54

4.2.3.1 Atividade sequestrante de radicais DPPH .............................. 54

4.2.3.2 Atividade sequestrante de radical superóxido $\left(\mathrm{O}_{2}{ }^{\circ-}\right) \ldots \ldots \ldots \ldots \ldots . . . . . . .55$

4.2.4 Avaliação do potencial citotóxico ............................................... 57

4.2.5 Avaliação do potencial fototóxico ................................................ 58

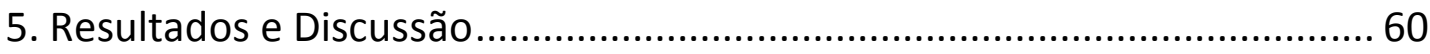

5.1 Síntese dos Análogos de Micosporinas ..............................................6 60

5.1.1 Padronização de métodos sintéticos limpos .................................. 60

5.1.2 Síntese dos compostos (1 a 12) ................................................. 62

5.1.3 Mecanismo reacional ................................................................. 65

5.1.4 Caracterização dos compostos ................................................ 67

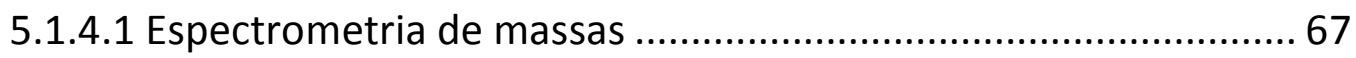

5.1.4.2 Ressonância nuclear magnética .............................................. 73

5.2 Análise das Propriedades Moleculares............................................. 78

5.2.1 Determinação do espectro de absorção de UV .............................. 78

5.2.2 Determinação do Coeficiente de Extinção Molar............................. 80

5.2.3 Determinação de potencial antioxidante ..................................... 82

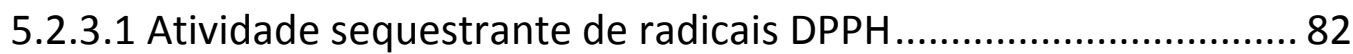

5.2.3.2 Atividade sequestrante de radical superóxido ......................... 84

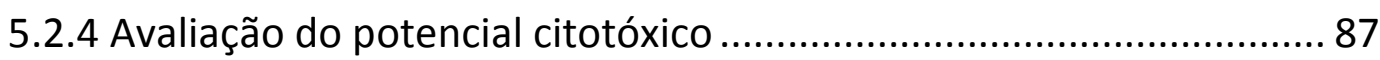

5.2.5 Avaliação do potencial fototóxico .................................................. 89

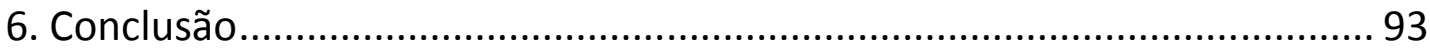

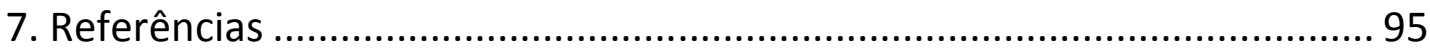




\section{LISTA DE FIGURAS}

Figura 1: Esquema mostrando as divisões da radiação solar, e em perspectiva as divisões da radiação UV.

Figura 2: Estrutura molecular de algumas das principais substâncias fotoprotetoras disponíveis no mercado, divididas pela faixa de proteção. A) substâncias com absorção na região da UVA e B) substâncias com absorção na região da UVB .......................................... 23

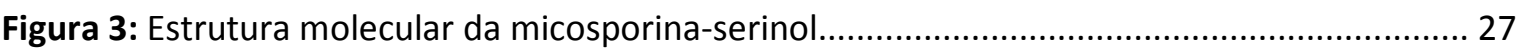

Figura 4: Estrutura molecular e absorção máxima $(\boldsymbol{\lambda})$ de MAA isoladas de organismos marinhos e o gadusol, intermediário da biossíntese de MAA. 28

Figura 5: llustração da pele mostrando suas três principais camadas, epiderme, derme e hipoderme e algumas das principais estruturas

Figura 6: Estruturas das substâncias utilizadas na reação de obtenção do ácido 2-(3oxociclohexilideneamino) propanóico (1) 46

Figura 7: Reação de redução da molécula de 2,2-difenil-1-picrilidrazila (DPPH) ........................... 54

Figura 8: Reação de redução da molécula de tetrazólio à formazana...........................................56

Figura 9: Estruturas dos diversos análogos obtidos. (1) AM-Ala; (2) AM-Met; (3) AM-Trp; (4) AM-Arg; (5) AM-Glu; (6) AM-Nle; (7) AM-Ser; (8) AM-4-n-Phe; (9) AM-Car; (10) AMHis; (11) AM-Tyr

Figura 10: Cromatograma gerado no processo de purificação do composto ácido 2-(3oxociclohexilideneamino) pentanodióico (5)

Figura 11: Esquema demonstrando os diversos passos da reação de formação dos análogos

Figura 12: Espectro de massas da substância ácido 2-(3-oxociclohexilideneamino) propanóico (1)

Figura 13: Espectro de massas da substância ácido 4-(metiltio)-2-(3oxociclohexilideneamino)butanóico (2).

Figura 14: Espectro de massas da substância ácido 3-(1H-indol-3-il)-2-(3oxociclohexilideneamino)propanóico (3)

Figura 15: Espectro de massas da substância ácido 5-guanidino-2-(3oxociclohexilideneamino)pentanóico (4).

Figura 16: Espectro de massas da substância ácido 2-(3-oxociclohexilideneamino) pentanodióico (5)

Figura 17: Espectro de massas da substância ácido 2-(3oxociclohexilideneamino)hexanóico (6)

Figura 18: Espectro de massas da substância ácido 3-hidroxi-2-(3-oxociclohexili deneamino propanóico (7)

Figura 19: Espectro de massas da substância ácido 2-(4-nitrofenil)-2-(3oxociclohexilideneamino) acético (8).

Figura 20: Espectro de massas da substância ácido 3-(1H-imidazol-5-il)-2-(3-(3oxociclohexilideneamino) propanamido)propanóico (9) 
Figura 21: Espectro de massas da substância ácido 3-(1H-imidazol-4-il)-2-(3oxociclohexilidene amino)propanóico (10)

Figura 22: Espectro de massas da substância ácido 2-(4-hidroxifenil)-2-(3oxociclohexilideneamino) acético (11). 72

Figura 23: Espectro de $\mathrm{RMN}{ }^{13} \mathrm{C}$ do ácido 2-(3-oxociclohexilideneamino) propanóico (1)........... 73

Figura 24: Zoom da região de 10 a 60 ppm do espectro mostrado na figura 23 ......................... 73

Figura 25: Espectro de $\mathrm{RMN}^{1} \mathrm{H}$ do ácido 2-(3-oxociclohexilideneamino) propanóico (1)........... 74

Figura 26: Zoom da região de 1 a 5.5 ppm do espectro mostrado na figura 25............................. 74

Figura 27: Espectro de RMN bidimensional $H M B C$ do ácido 2-(3oxociclohexilideneamino) propanóico (1) 75

Figura 28: Zoom da região de 1 a 4 ppm, do eixo das abscissas, do espectro mostrado na figura 27 75

Figura 29: Espectros de absorção de radiação ultravioleta obtidos nas análises dos análogos AM-Trp, AM-Arg, AM-Glu, AM-Nle, AM-Ser, AM-4-n-Phe, AM-Car, AM-His e AM-Tyr. O eixo das abscissas demonstra os comprimentos de onda compreendidos entre 190 e $400 \mathrm{~nm}$ e o eixo das ordenadas a intensidade da absorção.

Figura 30: Dados de porcentagem de inibição da formação do radical DPPH pelos compostos, AM-Glu, AM-Ser, AM-Car, AM-Arg, AM-His, AM-Trp, AM-Tyr, AM-4-n-Phe, AM-Nle e o controle positivo ácido Gálico. Dados relacionando percentual de inibição no eixo $Y$ com concentração utilizada no eixo $X$

Figura 31: Dados de porcentagem de inibição da formação de formazana pelos compostos, AM-Glu, AM-Ser, AM-Car, AM-Arg, AM-His, AM-Trp, AM-Tyr, AM-4-n-Phe, AM-Nle e o controle positivo ácido Gálico. Dados relacionando percentual de inibição no eixo $Y$ com concentração utilizada no eixo $X$

Figura 32: Dados de inibição da viabilidade celular, de fibroblastos expostos à diferentes concentrações das substâncias testadas e do padrão clorpromazina. Dados relacionando percentual de inibição no eixo das ordenadas versus concentração utilizada no eixo das abscissas.

Figura 33: Fotografia de culturas celulares de fibroblastos em aumento de 100x. Cultura A: Sem exposição a agentes químicos, com $100 \%$ das células viáveis, e cultura B: exposição a clorpromazina, restando um pequeno percentual de células viáveis 89

Figura 34: Curvas das substâncias e o controle CPZ, submetidos a exposição a radiação UVA. Dados relacionando percentual de inibição no eixo das ordenadas versus concentração utilizada no eixo das abscissas. 90

Figura 35: Curvas das substâncias e o controle CPZ, sem exposição a radiação UVA. Dados relacionando percentual de inibição no eixo das ordenadas versus concentração utilizada no eixo das abscissas. 


\section{LISTA DE TABELAS}

Tabela 1: Variação de alguns parâmetros para avaliação das condições sintéticas ideais nas reações realizadas em probe de ultrassom

Tabela 2: Variação de alguns parâmetros para avaliação das condições sintéticas ideais nas reações realizadas em forno de microondas utilizando água como meio reacional

Tabela 3: Variação de alguns parâmetros para avaliação das condições sintéticas ideais nas reações realizadas em forno de microondas empregando meio reacional sólido

Tabela 4: Produtos obtidos através de diferentes procedimentos reacionais ( $\mathbf{a}, \mathbf{b}$ e $\mathbf{c}$ ) envolvendo 1,3 ciclohexanodiona e diferentes aminoácidos. As reações a, b e c representam respectivamente as metodologias US, MO e FS.

Tabela 5: Rendimentos obtidos nas reações de obtenção dos diferentes compostos, descrição da aparência e ponto de fusão (PF ${ }^{\circ} \mathrm{C}$ ) dos mesmos. *nd - não definido, ocorreu decomposição a determinada tempertaura.

Tabela 6: Comprimentos de onda ( $\lambda$ máx) com absorções máximas dos compostos AMTrp, AM-Arg, AM-Glu, AM-Nle, AM-Ser, AM-4-n-Phe, AM-Car, AM-His e AM-Tyr. * compostos que apresentaram dois $\lambda$ máx

Tabela 7: Valores do coeficiente de absortividade $(\varepsilon)$ obtidos para os análogos, de acordo com a lei de Beer-Lambert

Tabela 8: Percentuais de inibição de formação do radical DPPH dos diferentes compostos testados (AM-Glu, AM-Ser, AM-Car, AM-Arg, AM-His, AM-Trp, AM-Tyr, AM4-n-Phe, AM-Nle e o controle positivo ácido Gálico) de acordo com a concentração final de cada composto em [ $\mu \mathrm{g} . \mathrm{mL}-1]$. Dados apresentados como \% de inibição \pm desvio padrão

Tabela 9: Percentuais de inibição de formação de formazana dos diferentes compostos testados (AM-Glu, AM-Ser, AM-Car, AM-Arg, AM-His, AM-Trp, AM-Tyr, AM-4-n-Phe, AM-Nle e o controle positivo ácido Gálico)de acordo com a concentração final de cada composto em [ $\mu \mathrm{g} \cdot \mathrm{mL}-1]$. Dados apresentados como \% de inibição \pm desvio padrão. 
1. INTRODUC 


\subsection{RADIACCÃO ULTRAVIOLETA (UVR)}

O espectro solar que atinge a superfície terrestre é formado predominantemente por UVR (100-400 nm), radiação visível (400-750 nm), e infravermelha (acima de $750 \mathrm{~nm}$ ), como demonstrado na figura 1. Nosso organismo percebe a presença destas radiações do espectro solar de diferentes formas. A radiação infravermelha (IV) é percebida sob a forma de calor, a radiação visível (Vis) através das diferentes cores detectadas pelo sistema óptico e a UVR através de reações fotoquímicas. Tais reações podem estimular a produção de melanina cuja manifestação é visível sob a forma de bronzeamento da pele (Neale et al., 1998; Flor et al., 2007).

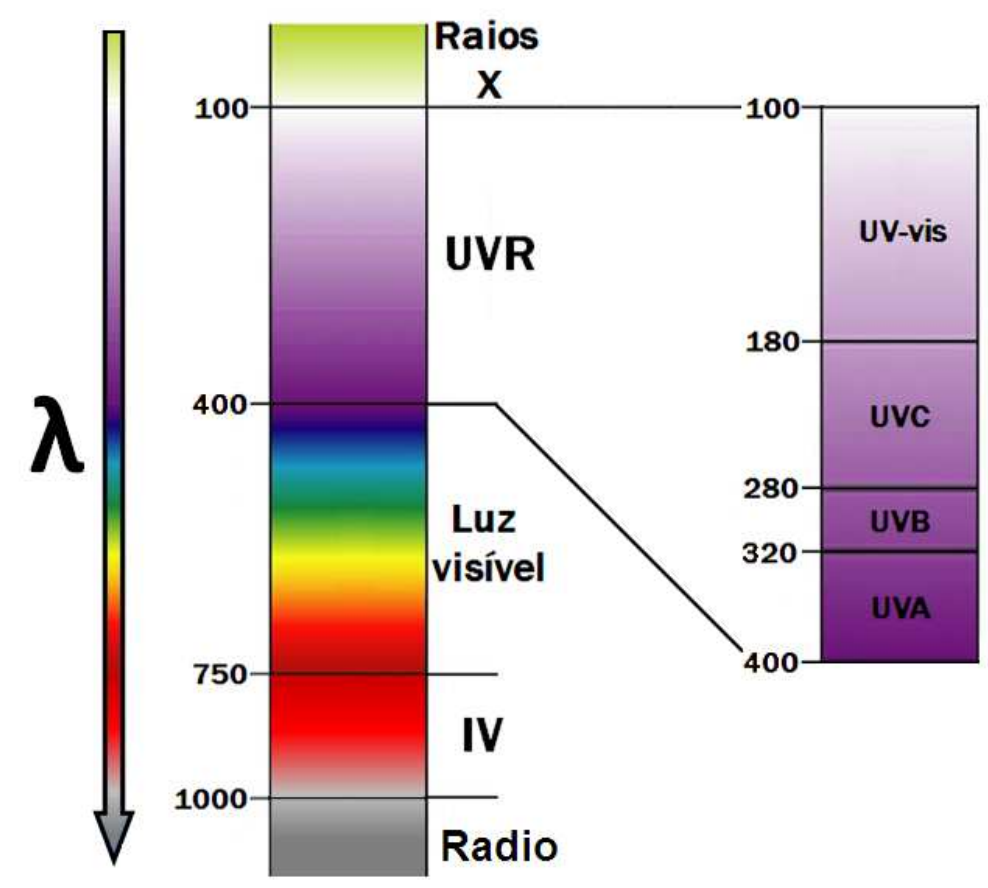

Figura 1: Esquema mostrando as divisões da radiação solar, e em perspectiva as divisões da radiação UV (adaptado de (Manahan, 2008)).

A energia da radiação aumenta com a redução do comprimento de onda, como a UVR é a de menor comprimento de onda é, consequentemente, a mais 
energética, ou seja, a mais propensa a induzir reações fotoquímicas. Uma consideração importante diz respeito à capacidade desta radiação permear a estrutura da pele. A UVA de energia menor penetra mais profundamente na pele e, ao atingir a derme é uma das responsáveis pelo fotoenvelhecimento (Ramos et al., 2005; Flor et al., 2007). A faixa da UVR (100 a $400 \mathrm{~nm}$ ) pode ser dividida em quatro partes, UVA (320 a $400 \mathrm{~nm})$, UVB (280 a $320 \mathrm{~nm})$, UVC (180 a $280 \mathrm{~nm}$ ) e UVR de vácuo (VUV, 100 a $180 \mathrm{~nm}$ ) (Thomas, 2000).

Frequentemente a radiação UVA não causa eritema; dependendo do tipo de pele e da intensidade da radiação recebida, o eritema causado é mínimo. Quando comparada à radiação UVB, sua capacidade em induzir eritema na pele humana é aproximadamente mil vezes menor, porém penetra mais profundamente na derme e é mais abundante na superfície terrestre (UVA 95\%, UVB 5\%). Induz pigmentação da pele promovendo o bronzeamento por meio do escurecimento da melanina pela fotoxidação da leucomelanina, localizada nas células das camadas externas da epiderme (Paola et al., 1998). Histologicamente causa danos ao sistema vascular periférico e induz o câncer de pele, dependendo do tipo de pele e do tempo, frequência e intensidade de exposição (Steiner, 1995). A radiação UVA também pode agir de maneira indireta, formando radicais livres, que por sua vez também estão relacionados com o desenvolvimento de câncer de pele (Osterwalder et al., 2000).

A radiação UVB atinge toda a superfície terrestre após atravessar a atmosfera. Possui alta energia e induz o bronzeamento da pele, sendo responsável pela transformação do ergosterol epidérmico em vitamina $D$, e causa o envelhecimento precoce das células (Steiner, 1995). A exposição frequente e intensa à radiação UVB pode causar lesões no DNA e levar à formação de espécies reativas, além de suprimir a resposta imunológica da pele. Desta forma, além de aumentar o risco de mutações, manifestada sob a forma de câncer de pele, sua atividade reduz a chance de uma célula maligna ser reconhecida e destruída pelo organismo (Streilein et al., 1994). 
A radiação UVC é portadora de elevadas energias, característica que a torna extremamente lesiva aos seres vivos (Streilein et al., 1994; Steiner, 1995). Devido à absorção pelo oxigênio e pelo ozônio na estratosfera, nenhuma radiação UVC, e uma pequena fração de UVB, chegam à superfície da Terra. Devido a fatores ambientais, a redução na camada de ozônio tem levado a um aumento da radiação UVB na superfície da Terra, ocasionando maior incidência de queimaduras e, consequentemente de casos câncer de pele. A Austrália vem tendo grandes problemas com os níveis de UVR devido a sua localização e à destruição em larga escala da camada de ozônio na Antártica, provocando maior incidência de câncer de pele. Fatores como estes justificam a preocupação com a destruição da camada de ozônio (Roy et al., 1995).

Durante as últimas décadas observamos o crescimento da preocupação em relação aos efeitos deletérios da incidência de radiação solar, principalmente pela ocorrência de depleção na camada de ozônio $\left(\mathrm{O}_{3}\right)$, uma barreira natural encontrada na estratosfera do nosso planeta, compreendida entre 16 e 30 quilômetros de altitude. $\mathrm{O} \mathrm{O}_{3}$ é um alótropo triatômico do oxigênio, muito menos estável que $\mathrm{O}_{2}$. Ele reduz os níveis de incidência de UVR, pelo mecanismo de equilíbrio entre as formas $\mathrm{O}_{3}$ e $\mathrm{O}_{2}$, absorvendo energia (Stapleton, 1992; Kerr e McElroy, 1993; Jordan e Callow, 1996; Mckenzie et al., 1999; He et al., 2002). A formação do buraco na camada de ozônio tem atraído a atenção científica para os efeitos danosos aos organismos ocasionados pela UVR. Este aumento de incidência de radiação afeta todas as formas de vida, direta ou indiretamente, especialmente organismos fotossintéticos, que necessitam de luz para sua sobrevivência (Stapleton, 1992; Jordan e Callow, 1996; Mckenzie et al., 1999; He et al., 2002).

Exposições prolongadas à UVR podem causar eritemas, edemas, esfoliações e hiperpigmentação, podendo ocasionar desde simples inflamações até graves queimaduras. Reações fotoalérgicas, entretanto, envolvem uma 
ativação do sistema imune. Neste caso, a luz solar promove reações entre as substâncias alergênicas e as proteínas da pele gerando uma resposta imunológica e posterior produção de anticorpos específicos. Há, também a possibilidade de ocorrerem comportamentos atípicos das células e mutações genéticas, cuja frequência tem aumentado nos últimos anos (Ramos et al., 2005; Flor et al., 2007).

Os perigos à saúde, relacionados à radiação UV, podem ser minimizados pelo emprego de protetores solares (Taylor et al., 1990), os quais estão no mercado há mais de 60 anos. Inicialmente, eles foram desenvolvidos para proteger a pele contra queimaduras do sol, isto é, preferencialmente contra a radiação UVB, permitindo o bronzeamento por meio de radiação UVA. Com o crescente conhecimento a respeito de UVA, ficou evidente que a pele precisaria ser protegida de toda a faixa UVA/UVB (Ziegler et al., 1994; Ananthaswamy et al., 1997), para reduzir o risco de câncer de pele causado por exposição ao sol. Em consequência, nasceu um novo conceito: um protetor solar eficiente deve prevenir não apenas uma possível queimadura, mas também reduzir o acúmulo de todas as lesões induzidas pela radiação UV que podem aumentar o risco de alterações fatais (Schueller e Romanowski, 2000). Proteger a pele frente às manifestações produzidas pela UVR significa converter a energia desta em outra forma de energia e ter garantias de que esta outra forma não seja prejudicial à pele. Os filtros UV empregados em formulações de protetores solares necessitam, também, serem fotoquimicamente estáveis (Flor et al., 2007).

\subsubsection{Tipos de filtros solares e mecanismos de ação}

Existem duas classes de filtros solares: orgânicos e inorgânicos. Nos filtros orgânicos temos a presença de compostos orgânicos e nos inorgânicos temos a presença de óxidos metálicos, como, o dióxido de titânio $\left(\mathrm{TiO}_{2}\right)$ e o óxido de 
zinco (ZnO) (Gasparro et al., 1998). Geralmente, os compostos orgânicos protegem a pele pela absorção da radiação e os inorgânicos, pela reflexão da radiação (Diffey e Grice, 1997; Gasparro et al., 1998).
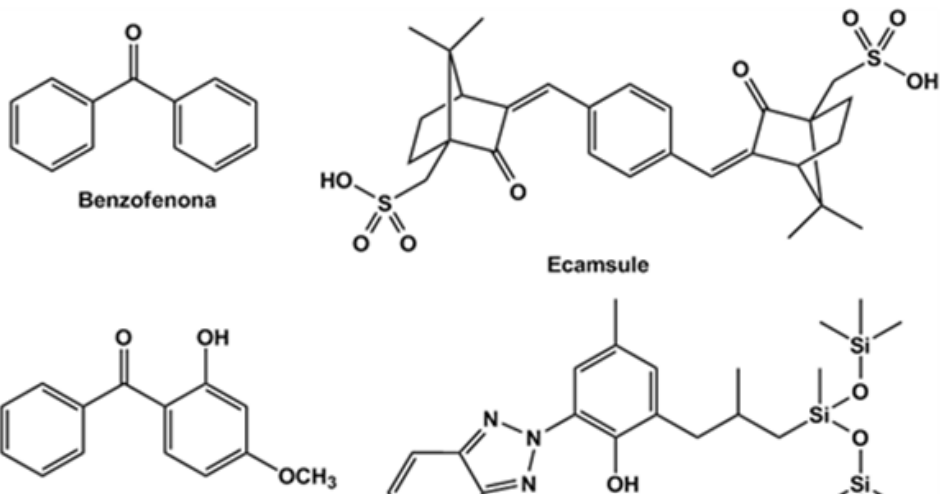

Avobenzona

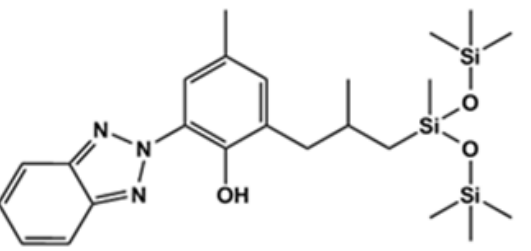

Silatriazol
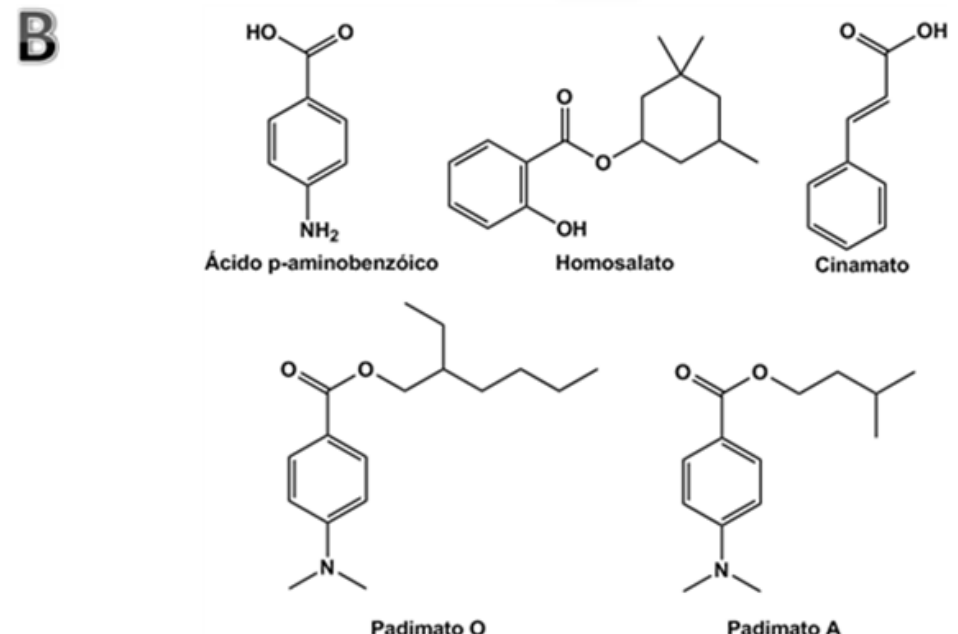

Padimato A

Figura 2: Estrutura molecular de algumas das principais substâncias fotoprotetoras disponíveis no mercado, divididas pela faixa de proteção. A) substâncias com absorção na região da UVA e B) substâncias com absorção na região da UVB.

A clase dos filtros orgânicos é formados por moléculas orgânicas capazes de absorver a radiação UV (alta energia) e transformá-la em radiações com energias menores e inofensivas ao ser humano. Estruturalmente, consistem em um anel aromático ligado a um grupo doador de elétrons, como uma amina ou um grupo metoxila, na posição orto ou para do anel (Gasparro et al., 1998). Ao 
absorver a radiação UV, os elétrons situados no orbital $\pi$ HOMO (orbital molecular preenchido de maior energia) são excitados para orbital $\pi^{*}$ LUMO (orbital molecular vazio de menor energia) e, ao retornarem para o estado inicial, o excesso de energia é liberado em forma de calor. As transições eletrônicas que estão envolvidas durante a absorção da luz UV ocorrem entre a diferença de energia HOMO - LUMO (Flor et al., 2007). Em alguns casos, dependendo da estrutura química em questão, a absorção da UVR pode ocorrer de acordo com um segundo mecanismo, que envolve uma reação de fotoisomerização cis-trans ou ceto-enol da estrutura, como por exemplo, na molécula de octilmetoxicinamato. Contudo, moléculas com este mecanismo de ação, sob incidência contínua de radiação perdem a capacidade de absorção e proteção por sofrerem uma alteração estrutural sendo, portanto, utilizadas em associações com outras substâncias (Gasparro et al., 1998; Gontijo et al., 2009). Também há um terceiro mecanismo de ação, semelhante ao descrito anteriormente, sendo a principal diferença o fato de que as reações de fotoisomerização auxiliam na absorção da radiação, como é o caso, por exemplo, da molécula de avobenzona, pois suas duas formas tautoméricas têm propriedades de absorção da radiação (Mturi e Martincigh, 2008).

\subsubsection{Estresse oxidativo por UVR}

Como citado anteriormente, a diminuição da camada de ozônio ocasionada por origem antropogênica, pela emissão de poluentes atmosféricos, trouxe como consequência um aumento no fluxo de UVR para a superfície terrestre (Kerr e McElroy, 1993; Cardozo, 2007). Este aumento é extremamente maléfico aos organismos, pois danos em biomoléculas como ácidos nucléicos, lipídios e proteínas, podem desencadear alterações de algumas funções celulares 
e são alguns exemplos dos efeitos deste excesso de radiação que podem levar os organismos à morte (Franklin e Forster, 1997).

A incidência de radiação UV sobre organismos também apresenta um efeito positivo sobre a geração de espécies reativas de oxigênio (EROs) tais como oxigênio singlete $\left({ }^{1} \mathrm{O}_{2}\right)$, ânion superóxido $\left(\mathrm{O}_{2}{ }^{-}\right)$, radical hidroxila $\left({ }^{\circ} \mathrm{OH}\right)$ e peróxido de hidrogênio $\left(\mathrm{H}_{2} \mathrm{O}_{2}\right)$ (Cadenas, 1989), que podem causar danos às estruturas celulares dos tecidos afetados através de interações com biomoléculas constitutivas como proteínas, ácidos nucléicos e ácidos graxos. Os organismos desenvolveram sistemas de proteção contra o efeito deletério destas EROs, constituídos de substâncias antioxidantes que têm como função primordial neutralizar a ação deletéria ocasionada pelas EROs (Obermuller et al., 2003; Yakovleva et al., 2004).

Em situações em que acontece um desequilíbrio entre os quocientes de ação das EROs em relação aos dos antioxidantes, com o predomínio dos primeiros, ocorre o estresse oxidativo. A peroxidação lipídica é uma forma de manifestação do estresse oxidativo e corresponde uma situação em que as EROs exercem seus efeitos deletérios sobre as cadeias lipídicas insaturadas da bicamada lipídica das membranas celulares, ocasionando destruição das estruturas, alteração da permeabilidade da membrana, debilitação do sistema de troca iônica e, em casos mais extremos, a morte celular (Obermuller et al., 2003; Yakovleva et al., 2004; Obermuller et al., 2005).

O efeito deletério do estresse oxidativo varia consideravelmente entre as espécies, e de acordo com a idade, estado fisiológico, patológico e nutricional. Desencadeia alterações funcionais das funções vitais, em diversos tecidos e órgãos, dentre eles: músculos, fígado, cérebro e tecidos adiposos e endoteliais (Quiroga, 1992; Duarte et al., 1993; Goldfarb, 1993; Signorini, 1993; Drogë, 2002; Fenster et al., 2002; Keynes e Garthwaite, 2004; Vancini et al., 2005). As EROs reagem com lipídios, proteínas, pigmentos e DNA, inativando suas funções biológicas. Estudos em mamíferos sugerem que a lipoperoxidação está 
relacionada diretamente com o mecanismo patogênico de várias patologias pulmonares, hepáticas, nervosas e cardíacas, entre elas aterosclerose, diabetes, doenças renais e Alzheimer (Halliwell e Gutteridge, 1999; Grotto et al., 2008).

As plantas, assim como os animais, são acometidas pelos efeitos deletérios produzidos por espécies reativas e por isso também desenvolveram sistemas antioxidantes. Dentre estes mecanismos de proteção, destacamos várias substâncias do metabolismo; por exemplo, terpenos oxidados, taninos, fenóis, alcalóides, lignanas, cafeína e aminas (Boscolo et al., 2007). Contudo, não só as plantas superiores apresentam moléculas constituintes com propriedades farmacológicas.

Muitos artigos descreveram a atividade antiinflamatória de extratos ou mesmo de moléculas já isoladas de algas. Guzmán e colaboradores, relataram em 2001, a atividade antiinflamatória, analgésica e antioxidante de extratos aquosos das microalgas Chlorella stigmatophora e Phaedactylum tricornutum(Guzmán et al., 2001). Além disso, estes organismos marinhos podem apresentar diferentes substâncias farmacologicamente ativas com atividades anti-helmíntica, anticoagulante, antidiabética, antifúngica, antimalarial, antiplaquetária, antiprotozoária, antituberculose, bactericida e virocida, além de atividades que afetam os sistemas cardiovascular e nervoso central (Mayer e Hamann, 2004; Mayer e Gustafson, 2008).

Uma vez que a inflamação pode estar associada à geração de EROs, muitas substâncias podem ter sua ação antiinflamatória devido a mecanismos antioxidantes. De acordo com o mencionado por Guzmán et al., as algas vêm sendo estudadas como potenciais fontes de substâncias antioxidantes. Dessa forma, a busca pela atividade antiinflamatória de extratos de várias polaridades de algas brasileiras como etapa inicial para o isolamento e caracterização de compostos responsáveis por essa atividade, torna-se absolutamente pertinente. 


\subsection{MICOSPORINAS}

Micosporinas são compostos naturalmente encontrados em algas e fungos, sendo utilizadas pelas mesmas, como mecanismo de defesa por serem potentes bloqueadores químicos de UVR. Elas foram primeiramente isoladas em fungos e por isso são denominadas micosporinas (Conde et al., 2000; Shick e Dunlap, 2002).

A primeira micosporina isolada, denominada $\mathrm{P}-310$, foi obtida a partir do fungo Stereum hirsutum, e sua estrutura hoje é elucidada como 2-metóxi-3-bis (hidroximetil) metilamino-5-hidróxi-5-hidroximetil-2-ciclohexeno (Favre-Bonvin e Arpin, 1976), mostrada na figura 3.

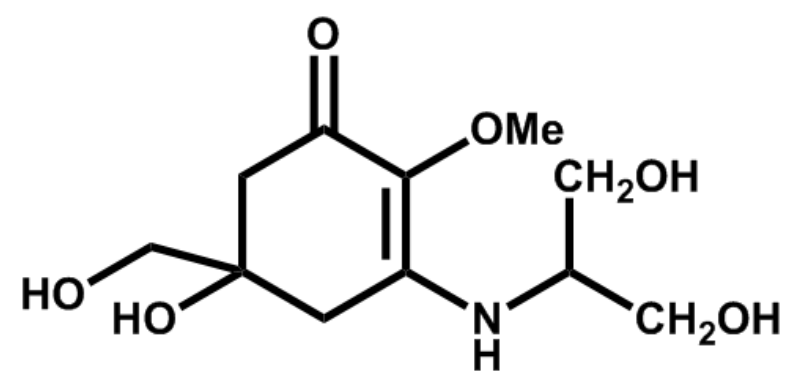

Figura 3: Estrutura molecular da micosporina-serinol.

Estas substâncias foram associadas à esporulação em fungos, provavelmente oferecendo proteção contra radiação UV durante a dispersão atmosférica destes esporos (Shick e Dunlap, 2002). Em organismos marinhos estas substâncias foram denominadas de "mycosporine-like amino acids" (MAA) (Nakamura et al., 1982). As MAA podem ser evidenciadas em organismos marinhos em regiões que abrangem o pólo até regiões tropicais; entretanto, ocorrem em maiores concentrações em espécies tropicais pela provável exposição a quantidades maiores de UV (Nakamura et al., 1982). As MAAs já foram encontradas em bactérias heterotróficas, cianobactérias, algas eucarióticas, organismos invertebrados marinhos e peixes (Sinha et al., 2000; 
Shick e Dunlap, 2002). Em organismos simbióticos também são encontradas as MAAs, caso em que as algas transferem tais compostos para os corais (Shick e Dunlap, 2002), e estes, por sua vez, utilizam as MAAs já existentes para gerar novas MAAs. Diatomáceas, dinoflagelados, algas vermelhas (rodofíceas) e algas verdes (clorofíceas) são alguns exemplos de algas que sintetizam MAA (Xiong et al., 1999; Klisch e Häder, 2000; Hoyer et al., 2001; Sinha et al., 2007). As estruturas de algumas MAA já isoladas estão mostradas na figura 4.

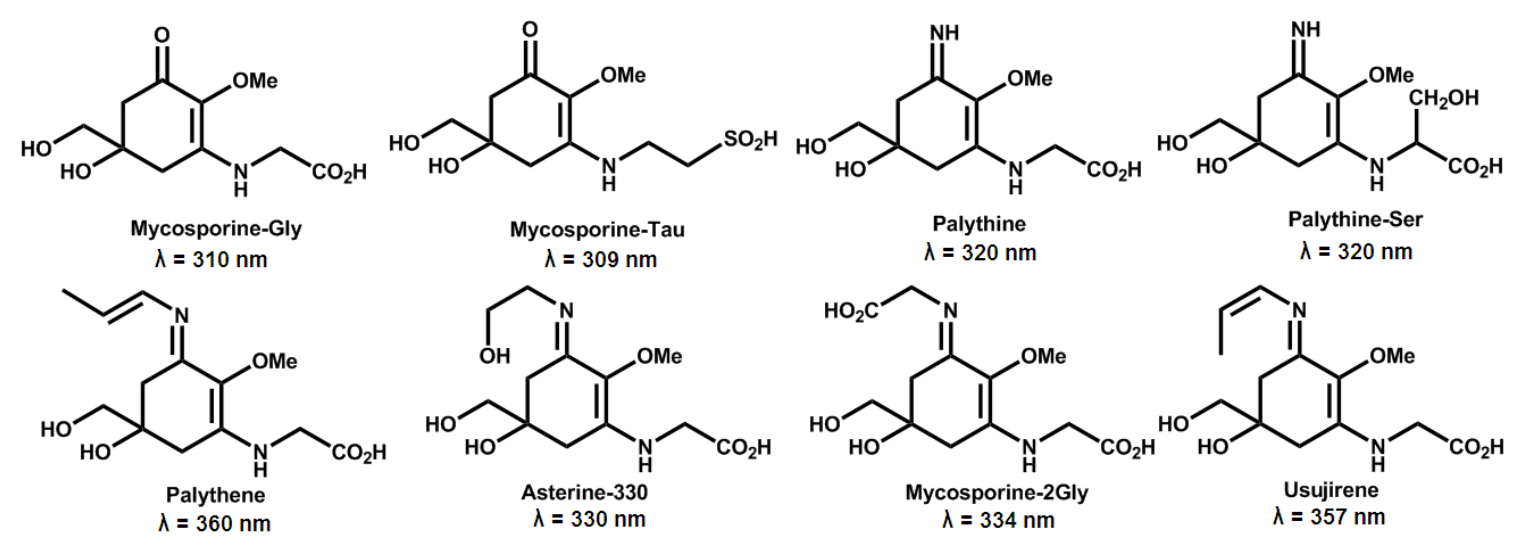<smiles>COC1=C(NCC(=O)O)CC(O)(CO)CC1=NC(=O)NCC(=O)O</smiles><smiles>COC1=C(NCC(=O)O)CC(O)(CO)CC1=NC(CO)CO</smiles><smiles>COC1=C(N(CCO)CCO)CC(O)(CO)CC1=NC(CCC(=O)O)C(=O)O</smiles><smiles>COC1=C(NCC(=O)O)CC(O)(CO)CC1=NC(C(=O)O)C(C)C</smiles><smiles>CC(O)C(O)CNC1=C(C(=O)O)C(=O)CC(O)(CO)C1</smiles>

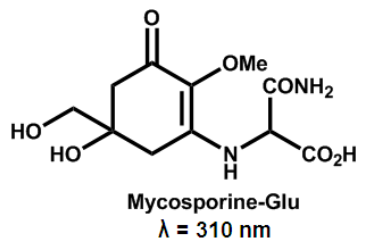

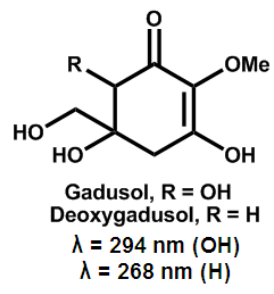

Figura 4: Estrutura molecular e absorção máxima $(\lambda)$ de MAA isoladas de organismos marinhos e do gadusol, intermediário da biossíntese de MAA (Shick e Dunlap, 2002).

Quimicamente, são caracterizadas por um anel ciclohexenona ou ciclohexenimina conjugado com o nitrogênio substituinte de um aminoácido, aminoálcool ou grupamento amino (Bandaranayake, 1998; Cardozo et al., 2008). 
São compostos altamente polares, de baixo peso molecular $(<400 \mathrm{~g} / \mathrm{mol})$, e geralmente com uma subunidade de glicina conjugada ao anel. Algumas MAA podem conter ainda, ésteres sulfatados. Apresentam uma absorção máxima nos comprimentos de onda compreendidos entre 310 e $360 \mathrm{~nm}$, demonstrados na figura 4, com alto coeficiente de extinção molar $\left(\varepsilon=28100-50000 \mathrm{M}^{-1} \mathrm{~cm}^{-1}\right)$ (Nakamura et al., 1982; Conde et al., 2000; Cardozo, 2007).

As plantas superiores não apresentam MAA; nelas, a proteção contra radiação UV é feita pelos flavonóides (Caldwell et al., 1983). Também não são encontradas em vertebrados superiores, nos quais a função protetora é assumida pela melanina (Cotran et al., 2000), e diferentemente de invertebrados e peixes, mamíferos aparentemente não absorvem estes compostos pela dieta (Nakamura et al., 1982). Apenas bactérias, fungos e algas sintetizam as MAA, sendo que os outros organismos marinhos adquirem as MAA pela dieta, simbiose ou associações com bactérias (Carroll e Shick, 1996).

Além da função de proteção contra radiação UV, sugere-se que as MAA possam exercer outras funções tais como antioxidantes (Dunlap e Yamamoto, 1995), osmóticas (p.e., cianobactérias em ambientes hipersalinos) e regulatórias da reprodução (Nakamura et al., 1982; Conde et al., 2000). Mecanismos celulares de defesa enzimática são frequentemente induzidos em condições de exposição à UVA (Dunlap e Yamamoto, 1995), sendo o papel de proteção antioxidante enzimático bem estabelecido. Pouco se conhece, entretanto, a respeito de pequenas moléculas antioxidantes na fotofisiologia de organismos marinhos.

Dunlap \& Yamamoto demonstraram que as oxicarbonilmicosporinas (micosporina-glicina e micosporina-taurina) possuem moderada atividade antioxidante, podendo assim funcionar como antioxidantes biológicos em organismos marinhos. Porém, iminomicosporinas como shinorine, porphyra-334, palitina, asterina-330 e palitinol não apresentam atividade antioxidante (Dunlap e Yamamoto, 1995). O efeito antioxidante de micosporina-glicina pode ser o responsável pela frequente observação de concentrações muito maiores desta 
MAA em corais crescendo em águas rasas comparados à mesma espécie crescendo em maiores profundidades (Shick e Dunlap, 2002; Conde et al., 2003).

O suposto precursor bioquímico das MAA, 4-deoxigadusol (4DG) (figura 4), é frequentemente observado como metabólito minoritário em algas e em simbioses entre algas e invertebrados. Diferentemente das iminomicosporinas, o 4-DG possui propriedades antioxidantes comparáveis ao ascorbato (Dunlap, Walter C et al., 1998; Shick e Dunlap, 2002). Trabalhos recentes demonstraram que a bactéria marinha Vibrio harveyi pode converter iminomicosporinas como shinorine e porphyra-334 em micosporina-glicina (Banaszak et al., 2000). As iminomicosporinas podem também ser convertidas ao forte antioxidante 4-DG através de fermentação com Vibrio sp. ou com diversas espécies do gênero Pseudoalteromonas, com rendimentos moderados. Investigações têm sido conduzidas para a produção comercial do 4-DG utilizando a via de retro-síntese, objetivando o uso deste antioxidante natural em ramos alimentícios e de cosméticos (Dunlap, Walter C et al., 1998). Outras aplicações comerciais para as MAA, tais como protetores solar e fotoestabilizadores de aditivos em plásticos, pinturas e vernizes vêm sendo pesquisadas (Bandaranayake, 1998; Cardozo et al., 2007). Com este propósito comercial, alguns análogos sintéticos das MAAs vêm sendo desenvolvidos, como as 3-alquilamino-2-metoxiciclohex-2-enonas (Dunlap, W.C. et al., 1998).

\subsection{QUÍMICA VERDE}

A questão ecológica ou uma maior preocupação com o meio ambiente surgiu no final da década de 1960 e tomou forte impulso nos anos 70. Atualmente, este é um assunto de grande relevância e enorme repercussão na sociedade (Sanseverino, 2000), tendo as indústrias químicas e farmacêuticas, e 
seus processos de obtenção de moléculas, como um dos focos principais de discussões.

No início da década de 90, uma nova tendência na maneira como a questão dos resíduos químicos deve ser tratada começou a tomar forma. Terminologias como tecnologia limpa, processo limpo, síntese limpa e química verde, têm se tornado muito frequentes na literatura nos últimos anos, sendo que já existem revistas especializadas nestes assuntos, como Journal of Cleaner Production e o Green Chemistry Journal (Torres, 1996; Wilkinson, 1997).

Esta visão do problema, com a proposição de novas e desafiadoras soluções, considera que, fundamentalmente, é preciso buscar uma alternativa que evite ou miniminize a produção de resíduos, em detrimento da preocupação exclusiva com o tratamento do resíduo no fim da linha de produção ("end of pipe") (Lenardão et al., 2003), ou mesmo a utilização de substâncias tóxicas ou perigosas (Sheldon et al., 2007). Este direcionamento na questão da redução do impacto da atividade química ao ambiente é chamado de "green chemistry".

Mais especificamente, falando de síntese limpa, tem-se procurado adotar posturas de redução, prevenção e eliminação de resíduos e a reutilização dos mesmos nos processos de obtenção de novas moléculas (Torres, 1996; Silva et al., 2005). Para alcançar a sustentabilidade nos processos sintéticos, existem alguns pontos e estratégias que devem ser levados em conta, como a utilização de solventes mais seguros e de formas alternativas de energia. Em relação às indústrias químicas e farmacêuticas, ou qualquer outra que ocasione a geração de substâncias poluentes, o desafio imposto pela química verde, é de minimizar ou mesmo evitar a formação de poluentes (Clark, 1999).

Como alternativa, na escolha por um solvente que sirva como meio reacional, atualmente, existem vários trabalhos utilizando a água (Sanseverino, 2000; Martins et al., 2006; Qu et al., 2009; Raihan et al., 2010), porém ainda encontra alguma resistência em sua utilização, devido ao fato de muitos compostos orgânicos terem uma baixa ou nula solubilidade, a incompatibilidade 
de intermediários, reagentes e catalisadores com ela e também devido à competição do processo desejado com hidrólise ou de reações com participação de água (King et al., 1992; Lubineau et al., 1994). Apesar disso, este solvente vem sendo amplamente utilizado por ser barato, normalmente disponível, não inflamável, não tóxico e que não polui o meio ambiente, o que representa um grande ganho ambiental (Sanseverino, 2000; Yu et al., 2010). Alternativa, em contrapartida à utilização de solventes orgânicos, é a utilização de líquidos iônicos, que conseguem atuar como meio reacional (não é inflamável nem volátil, termicamente estável, altamente polar) e catalisador (reutilizável) concomitantemente (Lenardão et al., 2003; Xin et al., 2010).

Outros tipos de reação que vem ganhando atenção como métodos limpos de obtenção de moléculas são as reações realizadas em fase sólida, utilizando diferentes meios reacionais, como sílica, alumina, carbonatos (Araújo et al., 1999; Li et al., 2008; Poinern et al., 2009) e algumas resinas consolidadas (resina Wang, Merrifield, Rink amide, Tentagel Rink, Ameba-poliestireno)(Graebin e Eifler-Lima, 2005). Em alguns casos, o rendimento obtido com esse tipo de reação é maior e com maior seletividade, do que quando a mesma reação é realizada com solvente. Uma das razões é que as moléculas em um cristal estão arranjadas de modo regular e mais próximas umas das outras do que na reação em meio líquido (Singh et al., 1994; Toda, 1995).

Um dos princípios básicos da química verde, é a busca pela eficiência de energia, onde a energia utilizada nos processos químicos precisa ser avaliada por seus impactos ambientais e econômicos, e deve ser minimizada. Procedimentos convencionais que requerem aquecimento ou resfriamento, por exemplo, demandam altas quantidades de energia, que muitas vezes é obtida de fontes não renováveis. Portanto, sempre que possível, os procedimentos devem ser realizados em condições de temperatura e pressão ambientes (Lenardão et al., 2003). 
Como alternativas nessa busca pela eficiência energética, encontramos algumas metodologias que utilizam microondas, ultrassom e energia mecânica, como fontes "não convencionais" de energia reacional (Luhken e Bader, 2002). As microondas são radiação eletromagnética não ionizante, que possuem frequências variando de 300 a 300.000 MHz, correspondendo a comprimentos de onda de $1 \mathrm{~mm}$ a $1 \mathrm{~m}$ (Sanseverino, 2002). Desde 1986, encontra-se na literatura relatos de utilização de microondas (Gedye et al., 1986; Giguere et al., 1986) (tanto reatores industriais quanto fornos domésticos) como fonte de energia, na maioria das vezes citado como sendo mais efetivo que as fontes convencionais de aquecimento, com tempos reacionais menores e rendimentos maiores, além de evitar a decomposição térmica(Sanseverino, 2002; Martins et al., 2003; Graebin e Eifler-Lima, 2005; Li et al., 2008). A aplicação desta forma de energia evidencia uma abordagem importante nos processos sintéticos limpos, pois pode ser utilizada em reações utilizando diferentes meios reacionais, tanto líquidos quanto sólidos (Sanseverino, 2002; Martins et al., 2003).

A utilização de ultrassom como fonte de energia reacional, chamada de sonoquímica, resulta em efeitos químicos devido ao fenômeno da cavitação acústica e a intensa agitação das moléculas presentes dissolvidas no meio quando expostos a ondas ultrassônicas de baixa frequência (< $1 \mathrm{MHz}$ ) (Suslick, 2001; Borges e Korn, 2002). O fenômeno da cavitação acústica, produzido por agitação mecânica, pode ser entendido pela formação de microbolhas, ocasionada pela passagem de uma onda acústica (ultrassônica), cuja intensidade supera as forças intermoleculares num determinado ponto do líquido. Quando estas microbolhas atingem seu diâmetro crítico ocorre um violento colapso das mesmas, liberando grandes quantidades de energia (Suslick, 1990; Gong e Hart, 1998; Suslick, 2001). Assim como no caso das reações empregando a energia gerada por microondas, as reações que utilizaram ultrassom como fonte de energia, obtiveram altos rendimentos e reduzidos tempos reacionais, quando comparados às técnicas convencionais(Luhken e Bader, 2002; Martins et al., 2006; Nandurkar et al., 2008; 
Park e Kim, 2008) demonstrando ser uma técnica bastante útil na obtenção de novas moléculas através de síntese limpa.

\subsection{TOXICIDADE}

Três elementos - toxicante, toxicidade e intoxicação - constituem a tríade básica da toxicologia, cuja finalidade primordial é promover condições seguras de convívio entre os agentes tóxicos e os organismos vivos, especialmente o homem. O termo segurança significa a probabilidade de uma substância não produzir dano sob determinadas condições de exposição e, consequentemente, o conceito recíproco, risco, é a probabilidade de uma substância produzir dano sob determinadas condições de exposição. Quando o risco não está sob controle, pode surgir a intoxicação, que é um desequilíbrio fisiológico causado por substâncias químicas endógenas ou exógenas, exteriorizado por meio de sinais e sintomas (Moraes et al., 1991; Lopes e Graff, 2006). A definição dada por Oga para o termo toxicidade remete a propriedade de agentes tóxicos promoverem injúrias às estruturas biológicas, por meio de interações físico-químicas, portanto é a capacidade inerente e potencial do agente tóxico provocar efeitos nocivos em organismos vivos(Oga, 2008).

A exposição dos seres vivos aos agentes tóxicos ocorre por várias maneiras, visto que o efeito tóxico depende primordialmente do agente químico alcançar e permanecer no sítio de ação (Oga, 2008). No caso de toxicidade dérmica, os efeitos tóxicos relacionados aos agentes químicos podem ser observados imediatamente, uma vez que representa um órgão imunocompetente, totalmente capaz de iniciar uma resposta inflamatória em resposta a alguns xenobióticos (Rogers e McDougal, 2002; Lorca et al., 2008), está muitas vezes exposto e pode ser facilmente atingido, até mesmo por simples deposição de partículas. Em contrapartida, apesar de estar exposta aos agentes 
externos, a pele é constituída por várias camadas (demonstrada na figura 5), formando uma barreira relativamente impermeável a muitos compostos, contendo em sua camada mais externa, o extrato córneo, formado por uma camada de queratina e que se apresenta como o fator determinante da absorção dos xenobióticos (Singh e Singh, 2001; Oga, 2008).

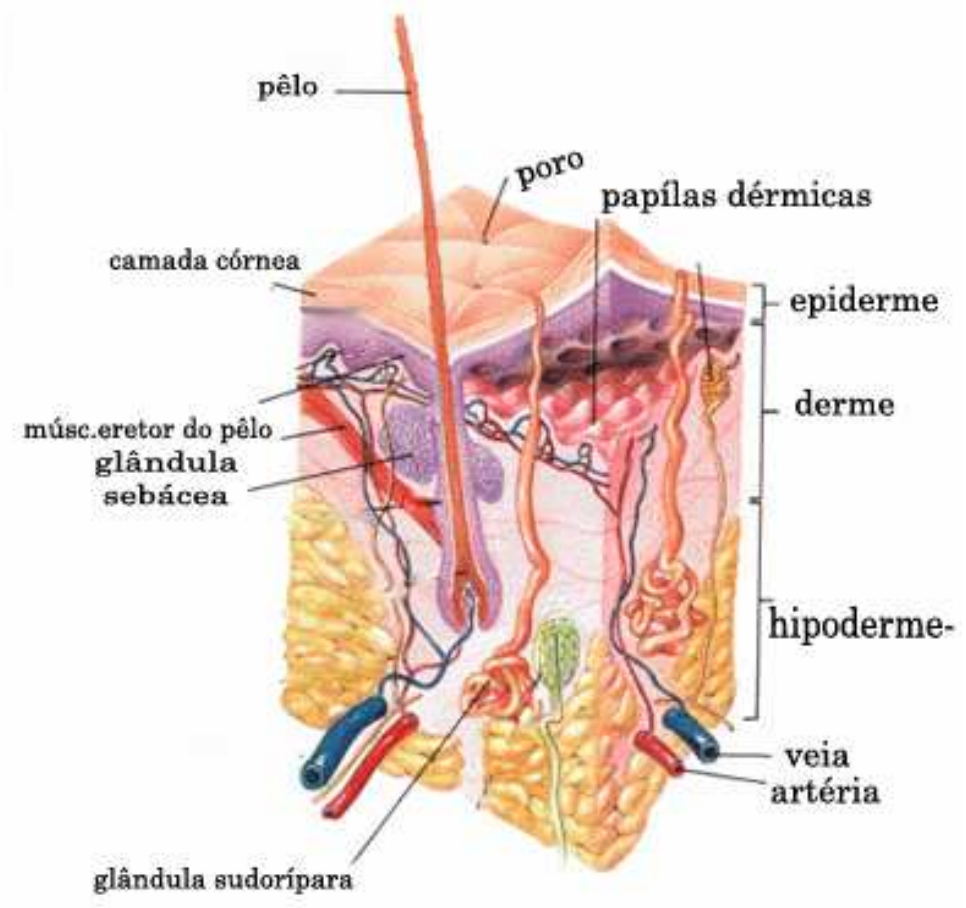

Figura 5: Ilustração da pele mostrando suas três principais camadas, epiderme, derme e hipoderme e algumas das principais estruturas (SEER, 2010).

Algumas substâncias possuem seu mecanismo deletério, atuando diretamente sobre a pele, causando danos na epiderme, como corrosão, sensibilização e até mesmo mutações no código genético celular (Draize et al., 1944; Rogers e McDougal, 2002). Quando ocorre corrosão, a lesão pode tanto ser superficial, quanto estendida aos tecidos mais profundos, formando assim uma porta de entrada para aquelas substâncias que antes não conseguia permear o extrato, exercerem efeitos sistêmicos deletérios, ou mesmo causar seus efeitos diretamente sobre as células, a citotoxidade (Singh e Singh, 2001; Oga, 2008). 


\subsubsection{Citotoxicidade}

As células, que representam a menor porção de matéria viva, são unidades estruturais e funcionais dos organismos vivos e possuem complexos sistemas de metabolismo, diferenciação e especialização. O conjunto destes sistemas desempenhados por um estado fisiológico normal é denominado homeostase celular. Quando a célula sofre algum tipo de estresse fisiológico, ocasionado por estados patológicos, processos inflamatórios ou agentes tóxicos, o processo de homeostase sofre um desequilíbrio, desencadeando adaptações celulares, e se o limite da resposta adaptativa for ultrapassado pelos efeitos do estresse, ocorre a lesão celular. Esta lesão pode ser irreversível e levar a um quadro de morte celular, basicamente por mecanismos de necrose ou apoptose (Cotran et al., 2000).

Quando o tecido em questão é o conjuntivo, o principal tipo de célula envolvida é o fibroblasto. Esse tipo de célula possui um citoplasma ramificado, rodeado de um núcleo elíptico contendo 1 ou 2 nucléolos, é responsável pela biossíntese do colágeno e da elastina além das glicosaminoglicanas e glicoproteínas multiadesivas, constituintes da matriz extracelular e também estão envolvidas na produção de fatores de crescimento. Os fibroblastos são capazes de modular sua capacidade metabólica, processo que reflete em sua morfologia. Diferenciam-se dos fibrócitos por seres ativos sintetizantes de metabólitos enquanto os fibrócitos são metabolicamente quiescentes (Bolsover et al., 2004; Junqueira e Carneiro, 2008; Lodish et al., 2008).

Como foi dito anteriormente, os efeitos tóxicos dérmicos, ocasionados por substâncias químicas, dependendo de sua extensão, ou das características físicoquímicas do agente químico, afetam diferentes níveis celulares. Os fibroblastos são algumas das células afetadas neste caso. Morfologicamente, podemos observar nestas células alguns sinais indicativos de toxicidade, como: vacuolização do citoplasma, granulação nuclear e arredondamento celular 
(ocasionado pelo descolamento da superfície a qual estão aderidos) (Martinez et al., 2002; Nathalie et al., 2006), porém inúmeras alterações a nível metabólico também ocorrem, decorrente do desequilíbrio homeostásico ou modificações no código genético celular, alterações que podem ser avaliadas por diversas metodologias analíticas (Mosmann, 1983; Rogers e McDougal, 2002; OECD, 2004; Nathalie et al., 2006; Valadares et al., 2007).

Uma das estimativas imprescindíveis na busca por novos produtos com ação farmacológica, com possível uso através de via tópica, é a avaliação do potencial de irritação da pele que estes produtos podem apresentar (Draize et al., 1944; Rogers e McDougal, 2002). Historicamente, esta avaliação era feita com estudos em animais (Draize et al., 1944) e mais tarde, em humanos (Basketter et al., 1997). Mais recentemente, métodos de experimentação in vitro vêm sendo desenvolvidas para realizar esta avaliação. Estes sistemas in vitro, oferecem uma vantagem sobre os sistemas in vivo por prover uma grande quantidade de informações, além de reduzir a utilização de animais de experimentação e comparar diferentes compostos sobre controladas condições. O propósito destes testes é classificar as substâncias em irritantes e não-irritantes, no entanto tais testes podem determinar também as condições de exposição (tempo e concentração) que desencadeiam a irritação, para uma correta avaliação do risco (Dupuis e Benezra, 1982; Rogers e McDougal, 2002). Os atuais métodos de avaliação in vitro utilizam culturas de queratinócitos, fibroblastos e culturas tridimensionais (Medina et al., 2000).

O efeito das substâncias irritantes leva a um quadro de lesão no nível celular, por exposição direta da pele a tais substâncias. Contudo, não somente substâncias ácidas ou corrosivas podem acarretar tais efeitos, pois nos últimos anos, com o desenvolvimento da indústria farmacêutica e cosmética, há inúmeras novas formulações que possuem a pele como via de absorção, além das formulações desenvolvidas para o próprio cuidado da pele, como cremes, géis, soluções bronzedoras e protetores solares. Todas estas formas farmacêuticas são 
constituídas de diferentes substâncias, que podem apresentar efeitos irritantes de acordo com os diferentes usuários. Porém, não devemos tomar cuidado somente com as substâncias químicas, pois a forma mais comum de agressão às células epiteliais não tem origem antropogênica, mas teve seus efeitos exacerbados pela ação dos mesmos, a radiação UV, que tem sua máxima ação em regiões do planeta onde a camada de ozônio é rarefeita ou mesmo inexistente. Esta radiação em altos níveis ou por um tempo prolongado de exposição, pode causar tantos efeitos (ou ainda mais) do que a exposição a agentes químicos. Quando ocorre um efeito sinérgico destas duas formas de toxicidade celular, ou seja, a ação de um composto sobre a pele, sob a incidência de luz solar, caracteriza-se um quadro de fototoxicidade

\subsubsection{Fototoxicidade}

A radiação ultravioleta é responsável por numerosos danos à pele, entre eles o eritema calórico, a queimadura solar, o fotoenvelhecimento, a fotossensibilidade e o mais grave entre eles, o câncer de pele. A fotossensibilidade pode gerar reações fotoalérgicas e fototóxicas (Epstein, 1999; Ramos et al., 2005). Estas últimas ocorrem geralmente quando uma substância fotorreativa é exposta à radiação solar e a radiações de comprimento de onda de 200 a 400 nm, que são as principais responsáveis por esta resposta cutânea. Esta toxicidade pode, ainda, ter duas classificações: fotodinâmica e não fotodinâmica. A diferença básica entre elas é que a primeira necessita de oxigênio para ocorrer (Epstein, 1999). Os principais efeitos destas reações são eritemas, edemas, esfoliações e hiperpigmentação. Reações fotoalérgicas, entretanto, envolvem uma ativação do sistema imune. Neste caso, a luz solar promove reações entre as substâncias alergênicas e as proteínas da pele gerando uma resposta imunológica e posterior produção de anticorpos específicos (Dupuis e Benezra, 1982). A 
exposição excessiva à luz solar pode causar, portanto, danos irreparáveis à pele, entre estes o mais grave, o câncer de pele, cuja maior incidência ocorre em países tropicais como o Brasil (Ramos et al., 2005).

Histologicamente, a morte celular epidermal ocorre na presença de uma substância hidrofílica, que não consegue permear o tecido, em exposição concomitante à UVR, através do processo de apoptose. No caso de substâncias, que possuem um determinado grau de lipofilicidade, e pode ser absorvida pela pele, as primeiras estruturas lesadas em um quadro de fototoxicidade são as células constituintes da derme, com poucos sinais de lesão ou ausência deles nas estruturas epidermais (Epstein, 1999). Este processo de lesão às estruturas celulares mais profundas da pele, também está relacionado ao tipo de radiação recebida pela pele, pois a radiação UVA tem um potencial de penetração maior em comparação com as UVB e UVC. Em contrapartida, uma determinada intensidade de radiação UVB pode aumentar em 1000 vezes o potencial fototóxico de uma substância, em comparação com a mesma intensidade recebida de radiação UVA (Tyrrell e Pidoux, 1987; OECD, 2004).

Como método de avaliação laboratorial da extensão desta agressão, encontramos os testes de citotoxicidade e fototoxicidade "in vitro", cujo reconhecimento pelos órgãos internacionais como a FDA e a OECD, favoreceu a substituição dos ensaios que utilizavam animais de laboratório (Huggett et al., 1996; Cruz et al., 1998). Nesses ensaios, as culturas celulares primárias são as que oferecem maior sensibilidade aos materiais tóxicos, porém, o uso de linhagens celulares contínuas apresenta uma série de vantagens por proporcionarem populações celulares mais homogêneas e possibilitarem a propagação contínua (Cruz et al., 1992; OECD, 2004) 
2. OBJETIVOS 


\subsection{OBJETIVO GERAL}

O trabalho proposto nesta dissertação teve como objetivo geral a elaboração de uma rota sintética apropriada, utilizando-se de princípios de síntese limpa, para obtenção de compostos análogos às moléculas de micosporinas. A partir da obtenção dos compostos, seus potenciais farmacológicos e toxicológicos foram avaliados, através de ensaios de absorção de radiação ultravioleta (UV), atividade antioxidante, ensaios citotóxicos e de fototoxicidade.

\section{$\underline{2.2}$ OBJETIVOS ESPECÍFICOS}

- Desenvolvimento de uma rota sintética limpa apropriada para a obtenção de moléculas análogas às micosporinas, baseada em princípios de química verde.

- Determinação de máxima absorção de radiação e coeficiente de extinção molar dos análogos.

- Avaliação dos compostos quanto ao seu potencial antioxidante.

$\rightarrow$ Metodologia de sequestro de radicais DPPH.

$\rightarrow$ Metodologia de sequestro de radical superóxido.

- Avaliação do potencial citotóxico dos compostos

- Avaliação do potencial fototóxico dos compostos 
3. JUSTIFICATIVA 
A síntese de compostos análogos de micosporinas que possuam propriedades farmacológicas semelhantes às encontradas em tais moléculas se torna importante, pela viabilidade econômica ocasionada pela utilização de substâncias precursoras e metodologias sintéticas de baixo custo, quando em comparação à obtenção de tais moléculas por extração de organismos marinhos, processo que demanda uma grande quantidade de biomassa para obtenção de quantidades limitadas da substância isolada. Além disso, a síntese de determinadas estruturas nos possibilita a alteração de fragmentos moleculares e grupamentos funcionais, com o intuito de obter a melhor resposta na relação estrutura-atividade e assim aperfeiçoar suas propriedades farmacológicas ou mesmo reduzir seu potencial toxicante.

Para equipararmos as propriedades observadas nas moléculas naturais com as moléculas sintetizadas, foram realizadas avaliações dos potenciais antioxidantes e de absorção de radiação UV das moléculas sintéticas e também ensaios toxicológicos.

Em relação à utilização de novas substâncias com fins farmacológicos, um problema pertinente é a toxicidade relativa destas substâncias em uma interação com o organismo humano. Portanto uma etapa importante no desenvolvimento de ativos farmacológicos é a avaliação do grau de toxicidade que as moléculas podem apresentar. No caso deste trabalho, foram avaliados a citotoxicidade e o potencial fototóxico das moléculas análogas às micosporinas em cultura de fibroblastos, uma vez que tais moléculas estão sendo avaliadas quanto ao seu poder de absorção de radiação UV com o intuito de futuramente poderem ser utilizadas em formulações fotoprotetoras. 


\section{METODOLOGIA}


Os solventes e reagentes utilizados no desenvolvimento das metodologias foram: 1,3-ciclohexanodiona (Acros Organics, EUA), NBT (Amresco, EUA), ácido acético glacial (LabSynth, Brasil), $\mathrm{D}_{2} \mathrm{O}$ (Cambridge Isotope Labs, Inglaterra), DPPH, DMSO, $\mathrm{CPZ}, \mathrm{Al}_{2} \mathrm{O}_{3}$ estandardizado (Merck, Alemanha), $\mathrm{MeOH}, \mathrm{Et}_{2} \mathrm{O}, \mathrm{CH}_{2} \mathrm{Cl}_{2}, \mathrm{Et}_{3} \mathrm{~N}$ graus analíticos, $\mathrm{MeOH}, \mathrm{ACN}, \mathrm{EtOH}$ espectroscópicos (Vetec, Brasil), sílica, aminoácidos, MTT, PMSN, NADH, fosfato dipotássico, ácido gálico, $\mathrm{CD}_{3} \mathrm{OD}$ (Sigma, Alemanha), DMEM, soro fetal bovino, glutamina, penicilina e estreptomicina (Invitrogen, Nova Zelândia).

\subsection{SÍNTESE DOS ANÁLOGOS DE MICOSPORINAS}

A proposta de determinação de uma rota sintética eficiente na obtenção de análogos de micosporinas foi desenvolvida utilizado princípios de química verde. Os procedimentos descritos a seguir seguem tais princípios, utilizando fontes alternativas de energia e sem a presença de solventes orgânicos nas reações de obtenção dos compostos de interesse a partir da molécula 1,3ciclohexanodiona e diferentes aminoácidos. Em um primeiro momento os procedimentos utilizados foram padronizados a fim de obter um melhor aproveitamento dos materiais de partida e, consequentemente, um melhor rendimento reacional.

\subsubsection{Padronização de métodos sintéticos limpos}

Primeiramente foram determinadas as condições sintéticas das metodologias propostas com o intuito de se obter a melhor condição sintética, dita como ideal, para obtenção de uma maior quantidade de produtos de interesse. Para isso foram aferidas três técnicas distintas: reação em meio aquoso 
utilizando probe de ultrassom (US) como fonte de energia reacional, reação em meio aquoso em forno de microondas (MO) e reação em meio sólido em forno de microondas (FS). Todos os testes se desenvolveram na reação envolvendo 1,3 ciclohexanodiona e o aminoácido alanina (ácido 2-aminopropanóico), com a formação do produto ácido 2-(3-oxociclohexili deneamino) propanóico (1). As análises foram realizadas em triplicata.

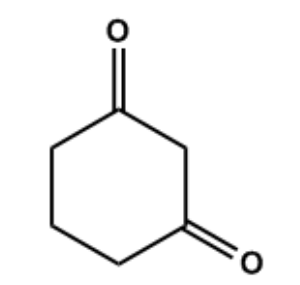

1,3 ciclohexanodiona<smiles>CC(N)C(=O)O</smiles>

alanina
(1)<smiles>CC(N=C1CCCC(=O)C1)C(=O)O</smiles>

ácido 2-(3-oxociclohexilideneamino) propanóico

Figura 6: Estruturas das substâncias utilizadas na reação de obtenção do ácido 2-(3oxociclohexilideneamino) propanóico (1)

Para as reações realizadas em US foi utilizado um equipamento Branson ${ }^{\circledR}$, modelo SLPt, foram avaliados os seguintes parâmetros: volume de solvente, amplitude da frequência do equipamento e tempo reacional. Os compostos precursores foram utilizados na concentração equimolar de $1 \mathrm{mM}$. As diferentes condições reacionais estão descritas na tabela 1. O tempo reacional descrito abaixo, diz respeito ao tempo total de incidência de energia, considerando que no equipamento, a frequência é aplicada por 1 minuto e é interrompido durante 1 minuto, a fim de evitar o aquecimento da probe, o que poderia danificar a mesma(Martins et al., 2006). 


\begin{tabular}{|c|c|c|c|}
\hline Reação US & Volume (mL) & $\begin{array}{l}\text { Amplitude da } \\
\text { frequência (\%) }\end{array}$ & $\begin{array}{c}\text { Tempo Reacional } \\
\text { (minutos) }\end{array}$ \\
\hline$A$ & 20 & 100 & $15-180$ \\
\hline B & 50 & 100 & $15-180$ \\
\hline C & 75 & 100 & $15-180$ \\
\hline $\mathrm{D}$ & 20 & 70 & $15-180$ \\
\hline$E$ & 20 & 50 & $15-180$ \\
\hline $\mathrm{F}$ & 20 & 25 & $15-180$ \\
\hline
\end{tabular}

Tabela 1: Variação de alguns parâmetros para avaliação das condições reacionais ideais nas reações realizadas em probe de ultrassom.

Nas reações realizadas em forno de microondas (Sanseverino, 2002; Martins et al., 2003; Yu et al., 2010), utilizando água como meio reacional, foram avaliados: o volume de solvente, a potência do equipamento e tempo de reação, demonstrados na tabela 2. Os compostos precursores foram utilizados na concentração equimolar de $1 \mathrm{mM}$. Para estas reações foi utilizado um forno de microondas marca Brastemp ${ }^{\circledR}$, modelo BMP40.

Tempo Reacional

\begin{tabular}{c|ccc|} 
Reação MO & Volume $(\mathrm{mL})$ & Potência (\%) & (minutos) \\
\hline A & 10 & 100 & $1-10$ \\
B & 20 & 100 & $1-10$ \\
C & 50 & 100 & $1-10$ \\
D & 75 & 100 & $1-10$ \\
E & 50 & 80 & $1-10$ \\
F & 50 & 60 & $1-10$ \\
G & 50 & 40 & $1-10$
\end{tabular}

Tabela 2: Variação de alguns parâmetros para avaliação das condições reacionais ideais nas reações realizadas em forno de microondas utilizando água como meio reacional.

A última metodologia avaliada, na reação desenvolvida em forno de microondas, porém, com meio reacional sólido $\left(\mathrm{Al}_{2} \mathrm{O}_{3} / \mathrm{SiO}_{2}\right)$ (Araújo et al., 1999; Sanseverino, 2002) foram avaliados: a potência do equipamento, os diferentes meios reacionais e tempo de reação. Os compostos precursores foram utilizados 
na concentração equimolar de $1 \mathrm{mM}$ homogeneizados em $4 \mathrm{~g}$ do meio reacional sólido, que foi uma mistura $\mathrm{Al}_{2} \mathrm{O}_{3} / \mathrm{SiO}_{2}$ em diferentes proporções. As diferentes condições reacionais estão descritas na tabela 3.

\begin{tabular}{c|ccc|}
\multicolumn{2}{c}{} & $\begin{array}{c}\text { Proporção } \mathrm{Al}_{2} \mathrm{O}_{3} / \mathrm{SiO}_{2} \\
(\%: \%)\end{array}$ & $\begin{array}{c}\text { Tempo Reacional } \\
\text { Reação FS }\end{array}$ \\
\hline A & $0: 100$ & 100 & $1-10$ \\
B & $25: 75$ & 100 & $1-10$ \\
C & $50: 50$ & 100 & $1-10$ \\
D & $75: 25$ & 100 & $1-10$ \\
E & $100: 0$ & 100 & $1-10$ \\
F & $50: 50$ & 80 & $1-10$ \\
G & $50: 50$ & 60 & $1-10$ \\
H & $50: 50$ & 40 & $1-10$ \\
\hline
\end{tabular}

Tabela 3: Variação de alguns parâmetros para avaliação das condições reacionais ideais nas reações realizadas em forno de microondas empregando meio reacional sólido.

\subsubsection{Síntese dos compostos}

Após a padronização das metodologias escolhidas para os procedimentos sintéticos, descritos abaixo, e comparação das mesmas, iniciaram-se as reações para obtenção dos compostos. Para isso o material de partida 1,3 ciclohexenodiona continuou sendo usado em reações que envolveram diferentes aminoácidos.

Procedimento a (US): Foi adicionado $1 \mathrm{mM}(1,12$ g) de 1,3ciclohexanodiona em $20 \mathrm{~mL}$ de água, juntamente a 1,05 mM do aminoácido, excedendo a proporção equimolar em $5 \%$. A solução foi mantida sob ação de ultrassom durante o tempo necessário para a formação máxima dos diferentes produtos. A formação de produto foi monitorada por espectrometria de massas. 
Procedimento b (MO): Foram adicionados 0,5 mM (0,55 g) de 1,3ciclohexanodiona em $50 \mathrm{~mL}$ de água, juntamente a 0,525 mM do aminoácido, excedendo a proporção equimolar em 5\%. A solução reagiu em forno de microondas durante o tempo necessário para a formação máxima dos diferentes produtos. A formação de produto foi monitorada por espectrometria de massas.

Procedimento $c$ (FS): Foram adicionados $0,5 \mathrm{mM}(0,55 \mathrm{~g})$ de 1,3ciclohexanodiona em $4 \mathrm{~g}$ de $\mathrm{Al}_{2} \mathrm{O}_{3} / \mathrm{SiO}_{2}$ 1:1, juntamente a $0,525 \mathrm{mM}$ do aminoácido, excedendo a proporção equimolar em $5 \%$. A mistura dos compostos foi homogeneizada e reagiu em forno de microondas durante o tempo necessário para a formação máxima dos diferentes produtos. A formação de produto foi monitorada por espectrometria de massas.

$\mathrm{Na}$ tabela seguinte (tabela 4) estão demonstradas as reações de US (a), MO (b) e FS (c) envolvendo os aminoácidos: alanina, metionina, triptofano, arginina, ácido glutâmico, leucina, serina, 4-nitro-fenilalanina, carnosina, histidina e tirosina, na obtenção dos compostos ácido 2-(3-oxociclohexili deneamino) propanóico (1), ácido 4-(metiltio)-2-(3oxociclohexilideneamino)butanóico (2), ácido 3-(1H-indol-3-il)-2-(3oxociclohexilideneamino)propanóico (3), ácido 5-guanidino-2-(3oxociclohexilideneamino)pentanóico (4), ácido 2-(3-oxociclohexilideneamino) pentanodióico (5), ácido 2-(3-oxociclohexilideneamino)hexanóico (6), ácido 3hidroxi-2-(3-oxociclohexilideneamino) propanóico (7), ácido 2-(4-nitrofenil)-2(3-oxociclohexilideneamino) acético (8), ácido 3-(1H-imidazol-5-il)-2-(3-(3oxociclohexilideneamino) propanamido)propanóico (9), ácido 3-(1H-imidazol-4il)-2-(3-oxociclohexilidene amino)propanóico (10), ácido 2-(4-hidroxifenil)-2-(3oxociclohexilideneamino) acético (11). 


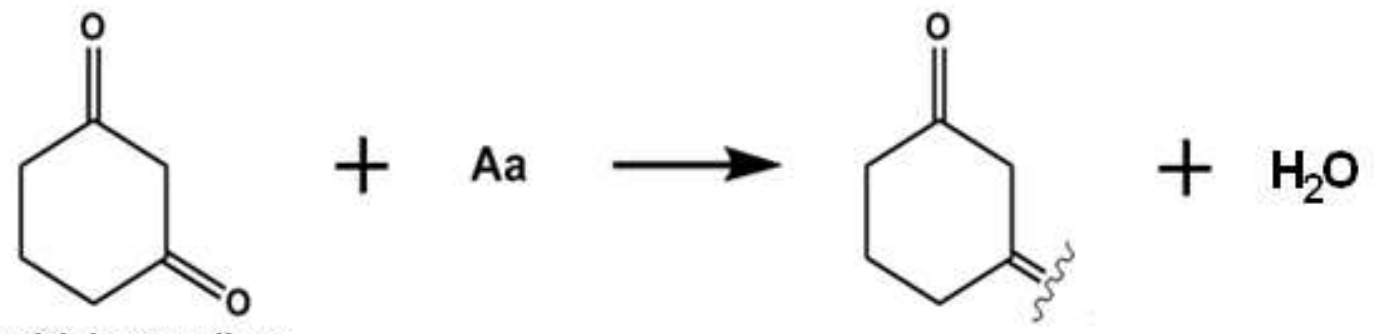

1.3 ciclohexanodiona

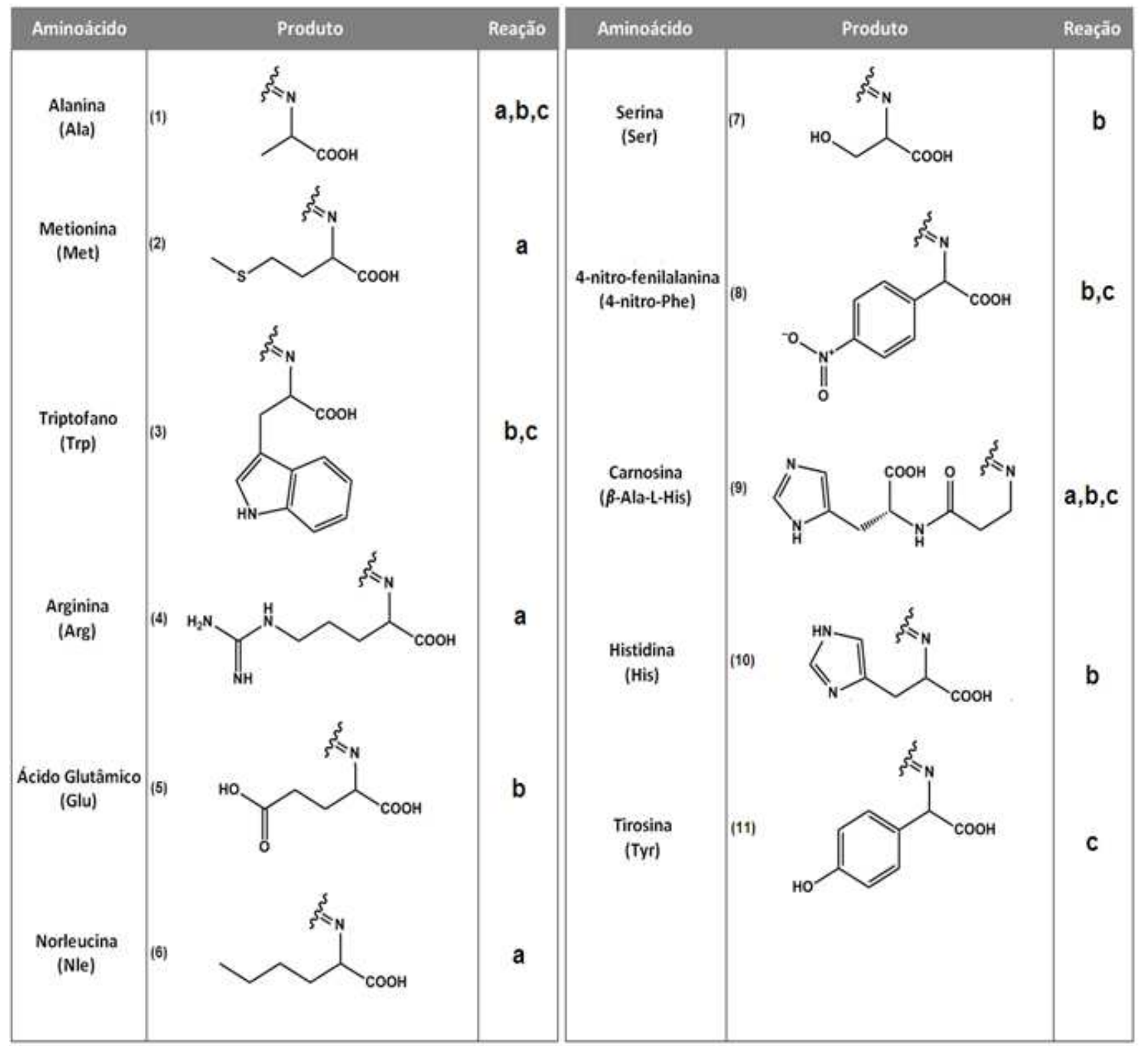

Tabela 4: Produtos obtidos através de diferentes procedimentos reacionais $(\mathbf{a}, \mathbf{b}$ e $\mathbf{c}$ ) envolvendo 1,3 ciclohexanodiona e diferentes aminoácidos. As reações $\mathbf{a}, \mathbf{b}$ e $\mathbf{c}$ representam respectivamente as metodologias US, MO e FS. 
Como alternativa no processo de purificação dos compostos, foi empregada a cromatografia preparativa, utilizando um cromatógrafo líquido de alta eficiência (HPLC) Shimadzu C LC - 6AD acoplado a um detector arranjo de fotodiodo (PDA, "Photodiode Array"), seguido de um coletor de frações.

Primeiramente foram desenvolvidos métodos cromatográficos efetivos para a separação dos compostos utilizando uma coluna Shim-pack PREP-ODS $(H)^{\circledR}$ C18 (4,6 x 250 mm), com detecção dos compostos realizada através de varredura de comprimentos de onda compreendidos entre 240 e $380 \mathrm{~nm}$. Diversas condições cromatográficas foram testadas, conforme a necessidade de modificação para aumentar ou diminuir o tempo de retenção dos compostos, tendo em vista o ajuste do tempo das corridas para menos de 10 minutos. Como fase móvel foi utilizada uma mistura de água Milli-Q e acetonitrila, em um fluxo de $0,8 \mathrm{~mL} /$ minuto, em diferentes proporções e diferentes gradientes de concentração até adequar o método para cada substância. Após a determinação dos métodos ideais, as coletas foram realizadas utilizando a coluna Shim-pack PREP-ODS $(\mathrm{H})^{\circledR} \mathrm{C} 18(20 \times 250 \mathrm{~mm})$, que possibilitou a coleta de maiores quantidades das substâncias. Com esta coluna, foi utilizado um fluxo de fase móvel de $10 \mathrm{~mL} /$ minuto, que resultou em uma pressão de trabalho por volta de 160 bar, a mesma utilizada nas corridas realizadas na coluna de $4,6 \mathrm{~mm}$ de diâmetro interno. 


\subsubsection{Caracterização Dos Compostos}

Os produtos obtidos nas reações anteriores foram caracterizados por métodos espectrométricos de análise de massas e ressonância magnética nuclear. O espectrômetro de massas utilizado foi um equipamento Applied Biosystems $^{\mathrm{TM}}$, modelo 3200Qtrap com ionização por eletrospray. Na técnica de ressonância magnética nuclear, os equipamentos utilizados nas análises de RMN ${ }^{1} \mathrm{H} \mathrm{e}^{13} \mathrm{C}$ foram o Bruker ${ }^{\odot}$ DRX-500 MHz e o Bruker ${ }^{\odot}$ DPX-300 MHz.

Os resultados das análises em espectrômetro de massas estão apresentados na forma de espectros, contendo as massas das estruturas protonadas dos compostos analisados e suas fragmentações. Os resultados das análises por RMN estão demonstrados através de deslocamentos químicos e constantes de acoplamento apresentadas pelas moléculas em questão.

\subsection{PROPRIEDADES DAS MOLÉCULAS}

A partir da obtenção dos compostos purificados com suas estruturas elucidadas, foram selecionados 10 destes para a determinação do espectro de absorção de radiação ultravioleta, realização dos ensaios de avaliação de potencial antioxidante e avaliação dos potenciais cito e fototóxicos.

A fim de facilitar a compreensão dos resultados, os compostos utilizados nos ensaios descritos a seguir foram nomeados de AM (análogo de micosporina) seguido da abreviação do nome do aminoácido correspondente ao utilizado na reação de obtenção do composto: (3) AM-Trp; (4) AM-Arg; (5) AM-Glu; (6) AMNle; (7) AM-Ser; (8) AM-4-n-Phe; (9) AM-Car; (10) AM-His; (11) AM-Tyr. 


\subsubsection{Determinação do Espectro de Absorção de UV}

Para determinação do espectro de absorção de UV das moléculas sintetizadas, foram utilizadas soluções a $0,5 \mathrm{mg} / \mathrm{mL}$ (acetonitrila:água 1:1) de cada composto de interesse.

O ensaio foi realizado, infundindo-se diretamente os compostos em um detector de arranjo de diodos Shimadzu modelo SPD - M10A e determinado o espectro de absorção de cada molécula na faixa de comprimentos de onda compreendidos entre 190 e 400 nm ("UV scanning").

\subsubsection{Determinação do Coeficiente de Extinção Molar}

O coeficiente de extinção molar, ou absortividade molar, é a capacidade de um mol de determinada substância absorver a luz a um dado comprimento de onda, em outras palavras, a quantidade de radiação, em um comprimento de onda específico, absorvida por um mol desta substância.

É um parâmetro intrínseco que está estritamente relacionado à eficácia apresentada por uma substância com propriedades fotoprotetoras, classificada como filtro orgânico (os filtros inorgânicos, ou físicos, tem sua ação pela refletância apresentada). A eficácia destes filtros aumenta proporcionalmente ao aumento do valor do coeficiente de extinção molar (Gontijo et al., 2009). Este parâmetro foi calculado a partir das leituras das absorbâncias dos compostos, em seus comprimentos de onda com máxima absorção, baseado na lei de BeerLambert, de acordo com a seguinte equação (resultados foram expressos em $\mathrm{M}^{-}$ $\left.{ }^{1} \mathrm{~cm}^{-1}\right)$ :

$$
\text { Abs }=C . I . \varepsilon
$$

Em que : C é a concentração das soluções

I é o caminho ótico

$\varepsilon$ é o coeficiente de absortividade

Abs é a absorção da solução testada 


\subsubsection{Determinação de Potencial Antioxidante}

\subsubsection{Atividade sequestrante de radicais DPPH}

O ensaio antioxidante utilizando DPPH (2,2-difenil-1-picrilidrazila, radical livre estável) fundamenta-se na propriedade deste radical extrair prótons de moléculas doadoras (como mostrado abaixo), reduzindo-se. O elétron desemparelhado na molécula de DPPH é responsável pela absorção em $517 \mathrm{~nm}$ e pela coloração violeta da substância. Após reação com moléculas antioxidantes, o DPPH recebe o elétron doado e a absorção é diminuída, sendo observada uma mudança na coloração para amarelo claro (Molyneux, 2004; Nazemiyeh et al., 2009) .

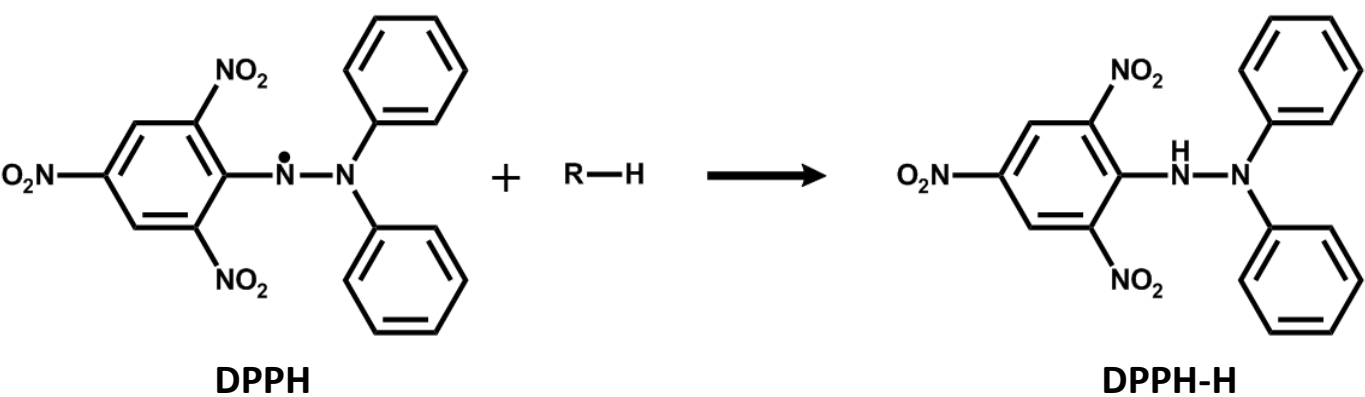

Figura 7: Reação de redução da molécula de 2,2-difenil-1-picrilidrazila (DPPH).

Para a determinação da atividade antioxidante, foram preparadas soluções de DPPH $1 \mathrm{mmol}^{-1}$ em etanol/água 1:1 e soluções em etanol/água 1:1 dos compostos a $2 \mathrm{mg} \cdot \mathrm{mL}^{-1}$. Em uma placa de 96 poços de fundo redondo foram adicionados $20 \mu \mathrm{L}$ da solução de DPPH e diferentes volumes da solução antioxidante para obtenção de concentrações de 31,25; 62.5; 125; 250 e 500 $\mu \mathrm{g} \cdot \mathrm{mL}^{-1}$ em um volume final de $200 \mu \mathrm{L}$ (o excedente foi completado com a solução de etanol/água 1:1). Após o preparo, as amostras foram incubadas por 30 minutos à temperatura de $25^{\circ} \mathrm{C}$ na ausência de luz e posteriormente levadas 
ao espectrofotômetro. O decréscimo da absorção foi medido em um comprimento de onda de $\lambda=517 \mathrm{~nm}$. Para cada concentração do composto testado foi descontado o branco (amostra sem DPPH). Os testes foram realizados em triplicata para cada concentração (Yokozawa et al., 1998; Pellati et al., 2004; Ferreres et al., 2006). Os resultados foram expressos em concentração molar.

O cálculo da porcentagem de inibição se deu através da equação:

$$
\% \text { Inibição }=\frac{\left(\text { Abs }_{\mathrm{DPPH}}-\mathrm{Abs}_{\mathrm{amostra}}\right)}{\mathrm{Abs}_{\mathrm{DPPH}}} \times 100
$$

Em que: $A_{\text {DPPH }}$ é a absorção sem solução teste Abs $_{\text {amostra }}$ é a absorção da solução teste

\subsubsection{Atividade sequestrante de radical superóxido $\left(\mathrm{O}_{2}{ }^{\circ-}\right)$}

Para a realização desta técnica, o radical superóxido $\left(\mathrm{O}_{2}{ }^{\circ-}\right)$ é gerado através do sistema PMS (metasulfato de fenazina) - NADH. O radical formado reage com NBT (tetrazólio nitroazul) produzindo formazana, que faz com que o meio passe da coloração amarela para violeta (medido espectrofotometricamente em 560 $\mathrm{nm})$. Na presença de substâncias com potencial antioxidante, os radicais superóxido são sequestrados por elas e a redução do tetrazólio é inibida, fazendo com que o meio mantenha a coloração amarela. A intensidade da coloração obtida é inversamente proporcional à concentração de antioxidante (Vellosa et al., 2007; Samak et al., 2009). 


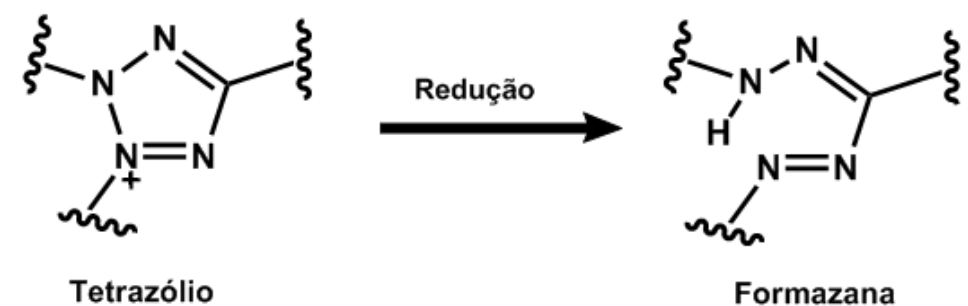

Figura 8: Reação de redução da molécula de tetrazólio à formazana.

O ensaio foi conduzido em tampão fosfato $(0,025 \mathrm{M}, \mathrm{pH} 8.3)$, adicionandose $2,5 \mu \mathrm{L}$ de PMS $372 \mu \mathrm{M}, 7,5 \mu \mathrm{L}$ de NBT $600 \mu \mathrm{M}$ e diferentes concentrações $\left(0,02 ; 0,04 ; 0,08 ; 0,16\right.$ e $\left.0,32 \mathrm{mg} \cdot \mathrm{mL}^{-1}\right)$ das substância testadas, em uma placa de 96 poços. Todos os poços utilizados foram completados com a solução tampão até atingir o volume final de $100 \mu \mathrm{L}$. A reação foi iniciada a partir da incorporação da solução de $5 \mu \mathrm{L}$ de NADH $1560 \mu \mathrm{M}$ NADH.

Depois de incubar a $25^{\circ} \mathrm{C}$ por 90 segundos, $10 \mu \mathrm{L}$ de ácido acético glacial e $90 \mu \mathrm{L}$ do tampão foram adicionados a solução, que foi agitada vigorosamente e posteriormente a intensidade da coloração resultante foi mensurada no comprimento de onda de $560 \mathrm{~nm}$. Para cada concentração da substância testada foi descontado o branco (amostra sem NADH). Os testes foram realizados em triplicata para cada concentração. Para grau de comparação, utilizou-se ácido gálico como controle positivo, por ter sua propriedade antioxidante conhecida.

O resultado está expresso relacionando a concentração molar dos compostos com o percentual de inibição da reação com o sal de tetrazólio partindo do radical, e foi determinado de acordo com a seguinte equação:

$$
\begin{aligned}
& \text { Inibição }(\%)=\left(1-\left(\text { Abs }_{\text {amostra }} / \text { Abs }\right)\right) \times 100 \\
& \text { Onde: Abs é a absorção do branco } \\
& A b_{\text {amostra }} \text { é a absorção da solução teste }
\end{aligned}
$$




\subsubsection{Avaliação do Potencial Citotóxico}

Para a determinação deste parâmetro, foram utilizadas culturas de fibroblastos 3T3, cultivados em meio DMEM (Dulbecco's Modified Eagle's Medium) suplementado com $10 \%$ soro fetal bovino, $4 \mathrm{mM}$ glutamina, penicilina (100 IU) e estreptomicina $(100 \mu \mathrm{g} / \mathrm{mL})$, sob condições controladas, temperatura de $37^{\circ} \mathrm{C}$ e $5 \%$ de $\mathrm{CO}_{2}$. As células foram mantidas em garrafas de cultura de $75 \mathrm{~cm}^{2}$ até atingirem a densidade de $1 \times 10^{5}$ células $/ \mathrm{mL}$, quando foram transferidas para placas de 96 poços, a uma densidade de $1 \times 10^{4}$ células/poço, onde ficaram incubadas por 24 horas. Após este tempo as células foram lavadas com PBS e incubadas com os compostos testados por 24 horas. As amostras testadas foram solubilizadas no próprio meio de cultura, nas concentrações de 1,$10 ; 0,55 ; 0,11$; 0,$055 ; 0,011 ; 0,0055 ; 0,0011$ e 0,00055 mg/mL. Posteriormente, as células foram novamente lavadas com PBS e incubadas por 3 horas com o corante MTT (Brometo de [3-(4,5-dimetiltiazol-2-il)-2,5-difeniltetrazólio], CAS 298-93-1). O MTT é um sal de coloração amarelada, que quando reduzido pelas enzimas redutases mitocondriais presente nas células resulta em uma coloração violeta intensa. Por fim o excesso de corante foi retirado e o restante foi solubilizado com DMSO. A solução final foi mensurada espectrofotometricamente em um comprimento de onda de $490 \mathrm{~nm}$, utilizando branco (poços sem células) como referência. Todas as análises foram realizadas em triplicata(Spielmann et al., 1998; OECD, 2004; Jaimes et al., 2006; Nathalie et al., 2006).

O percentual de viabilidade celular foi calculado de acordo com a seguinte equação:

$$
\% \text { viabilidade }=\left(\mathrm{Abs}_{\text {amostra }}-\mathrm{Abs}\right) /\left(\mathrm{Abs}_{\mathrm{controle}}-\mathrm{Abs}\right)
$$

Em que: Abs é a absorção do branco;

$$
\begin{aligned}
& A b s_{\text {amostra }} \text { é a absorção da solução teste; e } \\
& A b s_{\text {controle }} \text { é a absorção sem aplicação de xenobióticos }
\end{aligned}
$$


O IC 50 foi definido como a concentração necessária para diminuir em $50 \%$ a viabilidade das células expostas aos compostos. Para comparação, foi utilizada a substância clorpromazina (CPZ) como controle positivo nas avaliações, por ter seu potencial citotóxico conhecido. O controle foi avaliado nas concentrações de 0,$11 ; 0,055 ; 0,011 ; 0,0055 ; 0,0011 ; 0,00055 ; 0,00011$ e $0,000055 \mathrm{mg} / \mathrm{mL}$.

\subsubsection{Avaliação do Potencial Fototóxico}

Nos testes de fototoxicidade, as células foram preparadas como descrito no item 4.2.4, em duas placas idênticas, denominadas -IRR e +IRR, e após a primeira incubação de 24 horas o procedimento se desenvolveu de forma diferente.

As células foram lavadas e os compostos foram adicionados ao sistema, nas mesmas concentrações utilizadas na avaliação do potencial citotóxico. As células foram incubadas por 60 minutos na ausência de luz. Em seguida, a placa +IRR ficou exposta a radiação UVA por 50 minutos em uma intensidade de 5 $\mathrm{J} / \mathrm{cm}^{2}$ (maior dose de radiação considerada não citotóxica), enquanto a placa -IRR foi mantida no escuro. As células foram lavadas com PBS, reposto o meio de cultura, e as placas foram novamente incubadas por 24 horas. A radiação UVA foi obtida pela utilização de lâmpada Philips $^{\circledR}$ modelo F20T12/BL, com uma irradiância de $1,7 \mathrm{~mW} / \mathrm{cm}^{2}$.

O procedimento seguinte foi a determinação da viabilidade pelo método do corante MTT, no qual se procedeu da mesma maneira descrita no item anterior.

Com os valores de $I C_{50}$ definidos para as duas placas (-IRR e +IRR), foi calculado o fator de fotoirritação (PIF), que classifica a amostra como potencialmente fototóxica ou ausente desta propriedade. 
O PIF foi calculado da seguinte maneira:

$$
\mathrm{PIF}=I \mathrm{C}_{50}-\mathrm{IRR} / \mathrm{IC} \mathrm{C}_{50}+\mathrm{IRR}
$$

Quando o PIF $\geq 5$, a amostra é considerada fototóxica. Caso não tenha sido obtido o valor de $\mathrm{IC}_{50}$ para a placa -IRR até a concentração máxima testada, e na placa +IRR obteve-se um $I_{50}$, pode ser calculado o >PIF, de acordo com a equação(Spielmann et al., 1998):

$$
>\mathrm{PIF}=\mathrm{C}_{\text {máx }}-\mathrm{IRR} / \mathrm{IC} \mathrm{C}_{50}+\mathrm{IRR}
$$

Em que $C_{\text {máx }}$ é a máxima concentração testada na placa -IRR

Quando se encontra um valor >PIF maior que 1, pode-se dizer que a amostra é fototóxica. Da mesma forma como ocorrido no ensaio citotóxico, foi utilizado a substância clorpromazina como controle positivo, porque além de citotóxico ela possui um alto potencial fototóxico, sendo que sua toxicidade aumenta por volta de 15 vezes com exposição concomitante à UVA.

Estes ensaios foram realizados de acordo com as diretrizes de avaliação de produtos químicos da OECD. (Spielmann et al., 1998; OECD, 2004; Nathalie et al., 2006) 


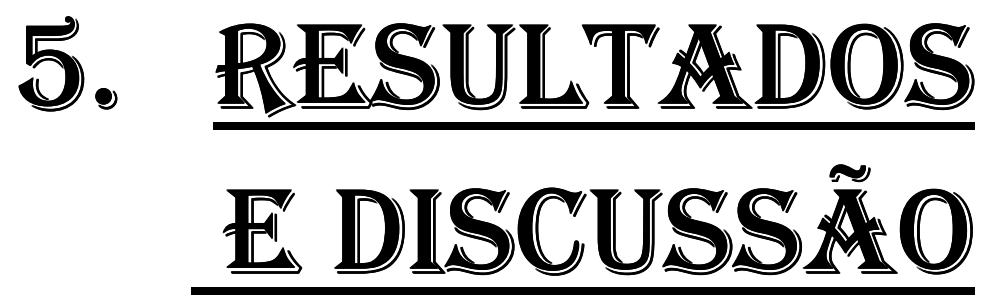




\subsection{SÍNTESE DOS ANÁLOGOS DE MICOSPORINAS}

\subsubsection{Padronização de Métodos Sintéticos Limpos}

Nas reações realizadas em probe de ultrassom, em que foram avaliados: o volume de solvente empregado, a frequência utilizada pelo equipamento e o tempo reacional, verificou-se uma obtenção mais acentuada de produto (1) na reação $E$ (tabela 1), quando se utilizou $20 \mathrm{~mL}$ de água Milli-Q como veículo reacional, amplitude de $50 \%$ da probe de ultrassom e tempo reacional de 360 minutos totais, portanto 180 minutos de incidência de energia. Nestas condições obteve-se um rendimento estimado de $56 \%$.

Nas reações realizadas em forno de microondas, utilizando água como meio reacional, foram avaliados os seguintes parâmetros: o volume de solvente, a potência do equipamento e tempo de reação. A maior formação do produto (1) foi observada na reação $C$ (tabela 2) quando os compostos precursores foram solubilizados em $50 \mathrm{~mL}$ de água Milli-Q e utilizado $100 \%$ da potência do forno de microondas em 5 minutos de reação. O rendimento estimado foi de aproximadamente $68 \%$.

Nas reações realizadas em forno de microondas, utilizando meio reacional sólido (uma mistura de $\mathrm{Al}_{2} \mathrm{O}_{3} / \mathrm{SiO}_{2}$ ), foram avaliados os seguintes parâmetros: a proporção dos componentes da fase sólida, a potência do equipamento e tempo de reação. A maior formação do produto (1) foi observada quando os compostos precursores foram submetidos às condições da reação $C$ (tabela 3 ) em que foi utilizada uma proporção igual de alumina e sílica ( 2 g de cada) e potência do forno de microondas de 100\% em 6 minutos de reação. Sob tais condições o rendimento estimado da reação foi de aproximadamente $77 \%$.

Um ponto importante a ser enfatizado é que o rendimento descrito neste item é somente um valor estimado, que foi obtido relacionando as áreas dos 
picos das substâncias envolvidas, gerados por infusão direta no espectrômetro de massas. O rendimento reacional real, que será apresentado no próximo item, foi calculado a partir da massa do produto em relação aos materiais de partida remanescentes no meio reacional ao final da reação. Cabe ressaltar também que os tempos reacionais obtidos nos testes de padronização das metodologias não são totalmente aplicáveis às reações com os outros aminoácidos, que obtiveram máximos rendimentos em tempos diferentes.

\subsubsection{Síntese dos Compostos (1 a 11)}

A "green chemistry" baseia-se em 12 princípios básicos, dos quais 5 foram utilizados nos processos de síntese descrito neste trabalho, a prevenção de geração de poluentes, a economia de átomos, a não formação de intermediários tóxicos, a utilização de solventes mais seguros e a busca pela eficiência de energia.

As reações de obtenção dos compostos (1 a 11), descritas na tabela 4 e demonstradas na figura 9, apresentaram diferentes comportamentos reacionais, bem como diferentes proporções de formação de produtos. As reações foram realizadas sob as diferentes metodologias, descritas como procedimento "a" (US) - reação em probe de ultrassom, procedimento "b"(MO) - reação em forno de microondas em fase aquosa e procedimento "c" (FS) - reação em forno de microondas em fase sólida. As metodologias se alternaram até a obtenção de um rendimento reacional considerado satisfatório (maior que $70 \%$ ). O cálculo do rendimento reacional foi realizado a partir da razão do valor da massa de produto pela massa total resultante da reação e multiplicando-se por 100 . O resultado está expresso em percentual de formação de produtos. O ponto de fusão dos compostos obtidos foi determinado através de análise em equipamento M-560 
Büchi@. Na tabela 5 estão demonstrados os rendimentos, aparência e ponto de fusão dos análogos sintetizados.

(1)<smiles>CC(N=C1CCCC(=O)C1)C(=O)O</smiles>

(2)<smiles>CSCCC(N=C1CCCC(=O)C1)C(=O)O</smiles>

(3)<smiles>O=C1CCCC(=NC(CC2=Nc3ccccc3C2)C(=O)O)C1</smiles>

(4)<smiles>N=C(N)NCCCC(N=C1CCCC(=O)C1)C(=O)O</smiles>

(5)<smiles>O=C(O)CCC(N=C1CCCC(=O)C1)C(=O)O</smiles>

(6)<smiles>CCCCC(N=C1CCCC(=O)C1)C(=O)O</smiles>

(7)<smiles>O=C1CCCC(=NC(CO)C(=O)O)C1</smiles>

(8)<smiles>O=C1CCCC(=NC(Cc2ccc([N+](=O)[O-])cc2)C(=O)O)C1</smiles>

(9)<smiles>O=C1CCCC(=NCCC(=O)NC(Cc2c[nH]cn2)C(=O)O)C1</smiles>

(10)<smiles>O=C1CCCC(=NC(Cc2c[nH]cn2)C(=O)O)C1</smiles>

(11)<smiles>O=C1CCCC(=NC(Cc2ccc(O)cc2)C(=O)O)C1</smiles>

Figura 9: Estruturas dos diversos análogos obtidos. (1) AM-Ala; (2) AM-Met; (3) AM-Trp; (4) AMArg; (5) AM-Glu; (6) AM-Nle; (7) AM-Ser; (8) AM-4-n-Phe; (9) AM-Car; (10) AM-His; (11) AM-Tyr.

\begin{tabular}{|c|c|c|c|c|}
\hline Produto & Reação & Rendimento \% & Aparência & $\mathrm{PF}^{\circ} \mathrm{C}$ \\
\hline (1) & c & 77,8 & Sólido marrom amarelado & nd \\
\hline (2) & a & 79,6 & Cristal marrom & nd \\
\hline (3) & c & 82,1 & Cristal amarelo claro & 242,8 \\
\hline (4) & a & 84,9 & Sólido marrom & 195,5 \\
\hline (5) & b & 90,4 & Sólido branco amarelado & 260,5 \\
\hline (6) & a & 86,7 & Sólido bege & nd \\
\hline (7) & b & 74,9 & Cristal amarelo & 170,9 \\
\hline (8) & c & 76,5 & Sólido amarelo & nd \\
\hline (9) & c & 72,0 & Sólido marrom amarelado & 190,5 \\
\hline (10) & b & 94,1 & Sólido marrom amarelado & 170,0 \\
\hline (11) & C & 85,2 & Sólido amarelo claro & 226,8 \\
\hline
\end{tabular}

Tabela 5: Rendimentos obtidos nas reações de obtenção dos diferentes compostos, descrição da aparência e ponto de fusão $\left(\mathrm{PF}{ }^{\circ} \mathrm{C}\right)$ dos mesmos. ${ }^{*}$ nd - não definido, ocorreu decomposição a determinada temperatura. 
As reações realizadas resultaram em diferentes percentuais de rendimento que variaram de acordo com a técnica utilizada, bem como diferentes aminoácidos resultaram em rendimentos diferentes quando foi utilizada a mesma técnica. Em um olhar geral, as técnicas realizadas em forno de microondas obtiveram um rendimento maior $(72,0$ - 94,1 \%), em relação às reações realizadas sob ação de ultrassom ("a": 79,6 - 86,7 \%), com um aproveitamento melhor nas reações realizadas em água ("b": 74,9 - 94,1\%) quando em comparação às reações em fase sólida ("c": 72,0 - 85,2). Entretanto, todas as metodologias avaliadas se mostraram efetivas na obtenção dos compostos e podem ser utilizadas com o intuito de se obter diferentes análogos das micosporinas.

No processo de purificação das substâncias, não foi possível se adotar um único método que fosse útil ao processo de purificação de todos os compostos sintetizados. Para atender ao requisito de os compostos apresentarem um baixo tempo de retenção, foram desenvolvidos métodos individuais para cada análogo sintetizado. Utilizando diferentes métodos cromatográficos, com a coluna Shimpack PREP-ODS $(\mathrm{H}){ }^{\circledR} \mathrm{C} 18(20 \times 250 \mathrm{~mm}, 5 \mu \mathrm{m})$, conseguiu-se isolar os produtos das reações dos resquícios de materiais de partida encontrados no meio reacional. Para exemplificar o isolamento, na figura 10, está demonstrado um cromatograma de uma corrida cromatográfica no processo de purificação do análogo ácido 2-(3-oxociclohexilideneamino) pentanodióico (5), que tem um tempo de retenção de 4,9 minutos, enquanto a 1,3-ciclohexanodiona tem um tempo de 6,6 e o ácido glutâmico 8,4 minutos. 


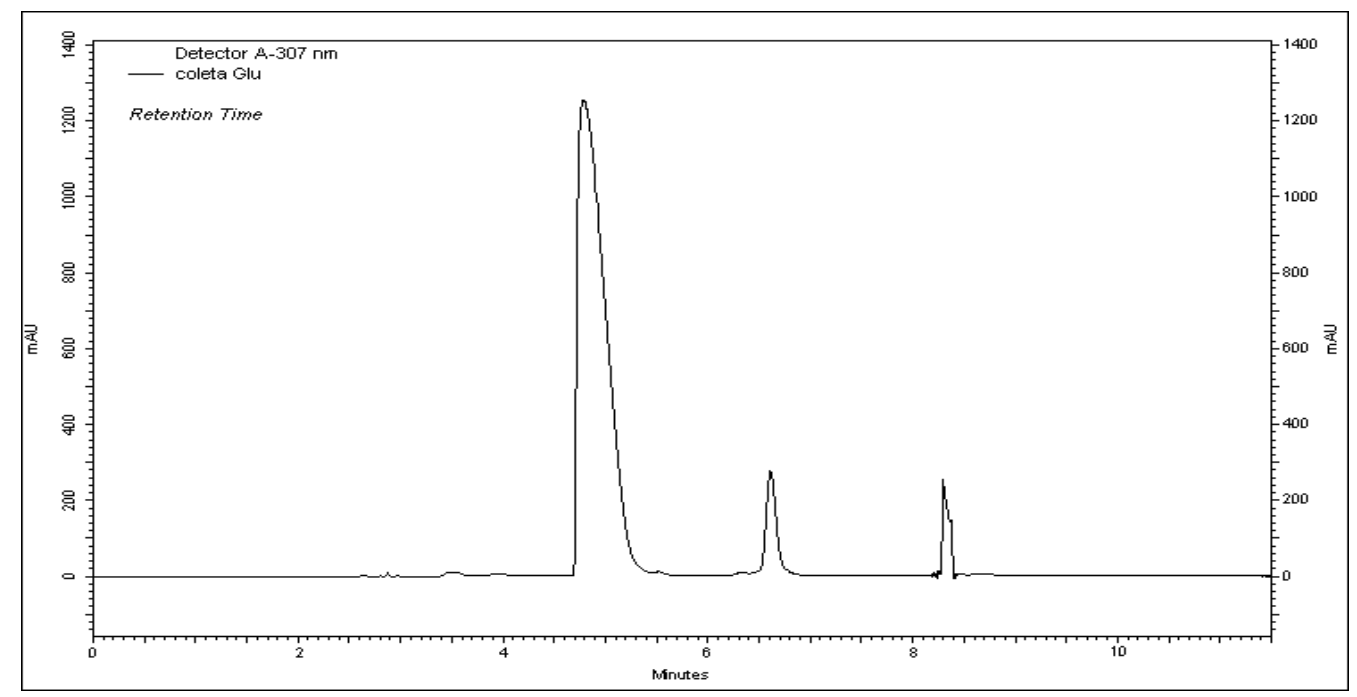

Figura 10: Cromatograma gerado no processo de purificação do composto ácido 2-(3oxociclohexilideneamino) pentanodióico (5).

\subsubsection{Mecanismo reacional}<smiles>[R]NC1([O-])CCCC(=O)C1</smiles><smiles>[R][CH+]1C[C@@H]2CC[C@H]1C2=NC1CCCC(=O)C1</smiles><smiles>[R][NH+]=C1CCCC(=O)C1</smiles><smiles>[R]NC1([2H])CCCC(=O)C1</smiles>

Figura 11: Esquema demonstrando os diversos passos da reação de formação dos análogos. 
Nas reações de obtenção dos análogos de micosporinas, os reagentes precursores foram solubilizados em água. Os elétrons do grupamento amino estabelecem uma ligação com o carbono cetônico, devido ao caráter eletrofílico que o carbono apresenta quando ligado a um átomo parcialmente negativo, transferindo a dupla ligação e deixando o oxigênio com carga negativa. 0 seguinte equilíbrio é formado pela incorporação de um hidrogênio proveniente do meio reacional ao oxigênio que se encontrava negativo, e que posteriormente recebe um segundo átomo de hidrogênio que tanto pode ser proveniente do grupamento amino quanto do meio reacional rico em hidrogênio, formando assim uma hidroxila protonada. Esta hidroxila caracteriza um grupamento de saída mais forte que o grupamento amina. Então ocorre a saída da hidroxila protonada, deixando a amina, carregada positivamente, incorporada ao anel e gerando assim uma molécula de água. A amina positiva é estabilizada quando libera seu hidrogênio no meio reacional. 


\subsubsection{CARACTERIZACÃO DOS COMPOSTOS}

Todos os produtos das reações, previamente purificados, foram caracterizados por métodos espectrométricos de análise de massas e ressonância magnética nuclear. Abaixo, podemos visualizar os espectros de massas e os espectros de RMN ${ }^{1} \mathrm{H}$ e RMN ${ }^{13} \mathrm{C}$ dos compostos.

\subsubsection{Espectrometria de Massas}

Os espectros foram obtidos por infusão direta dos compostos em um espectrômetro de massas Applied Biosystems 3200Qtrap com detector do tipo triplo quadrupolo, em modo de ionização positivo. Abaixo estão demonstrados os espectros gerados nas infusões das diferentes substâncias, mostrando o pico da molécula protonada e seus principais fragmentos.

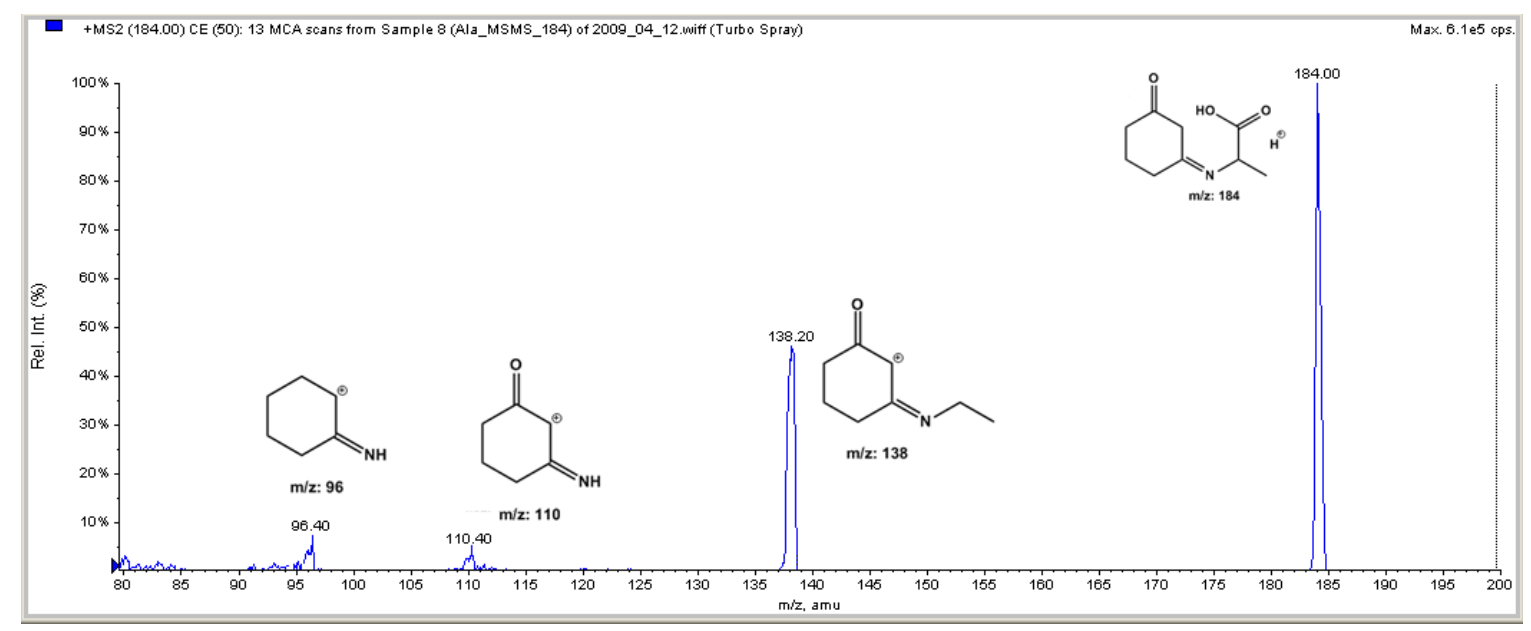

Figura 12: Espectro de massas da substância ácido 2-(3-oxociclohexili deneamino) propanóico (1). 


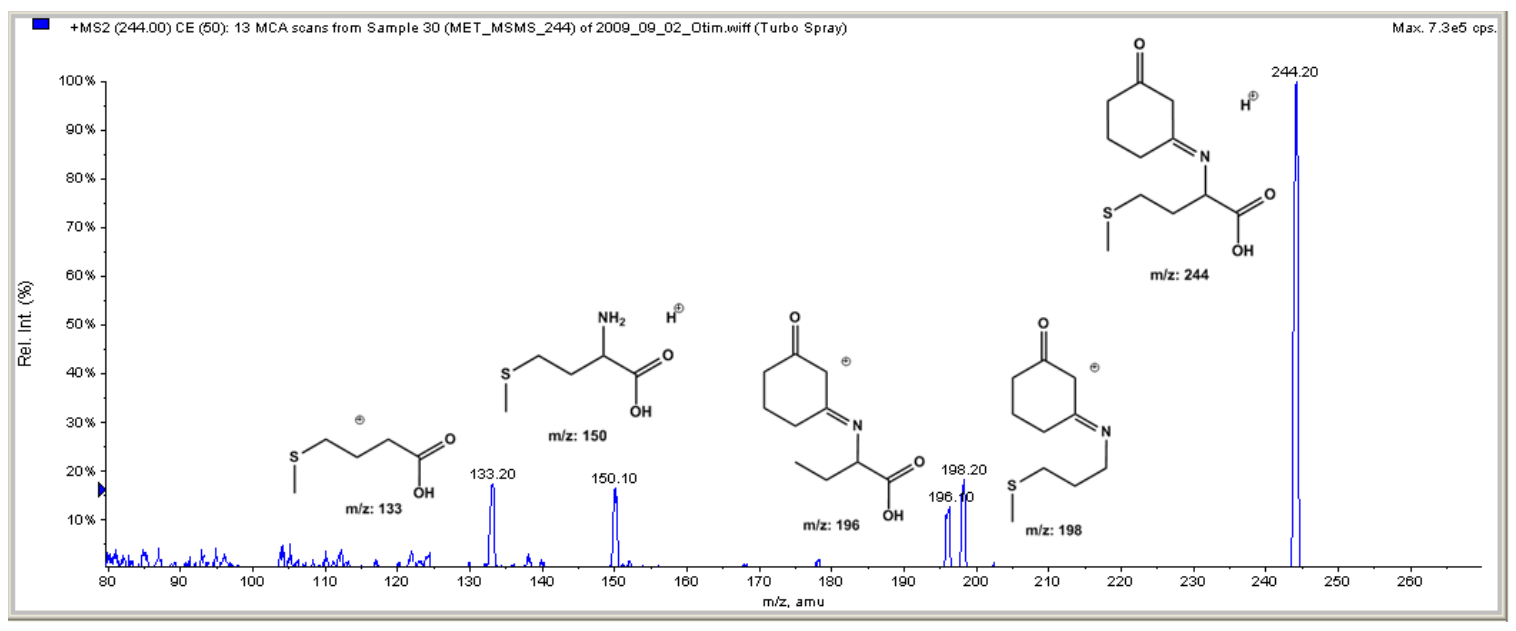

Figura 13: Espectro de massas da substância ácido 4-(metiltio)-2-(3oxociclohexilideneamino)butanóico (2).

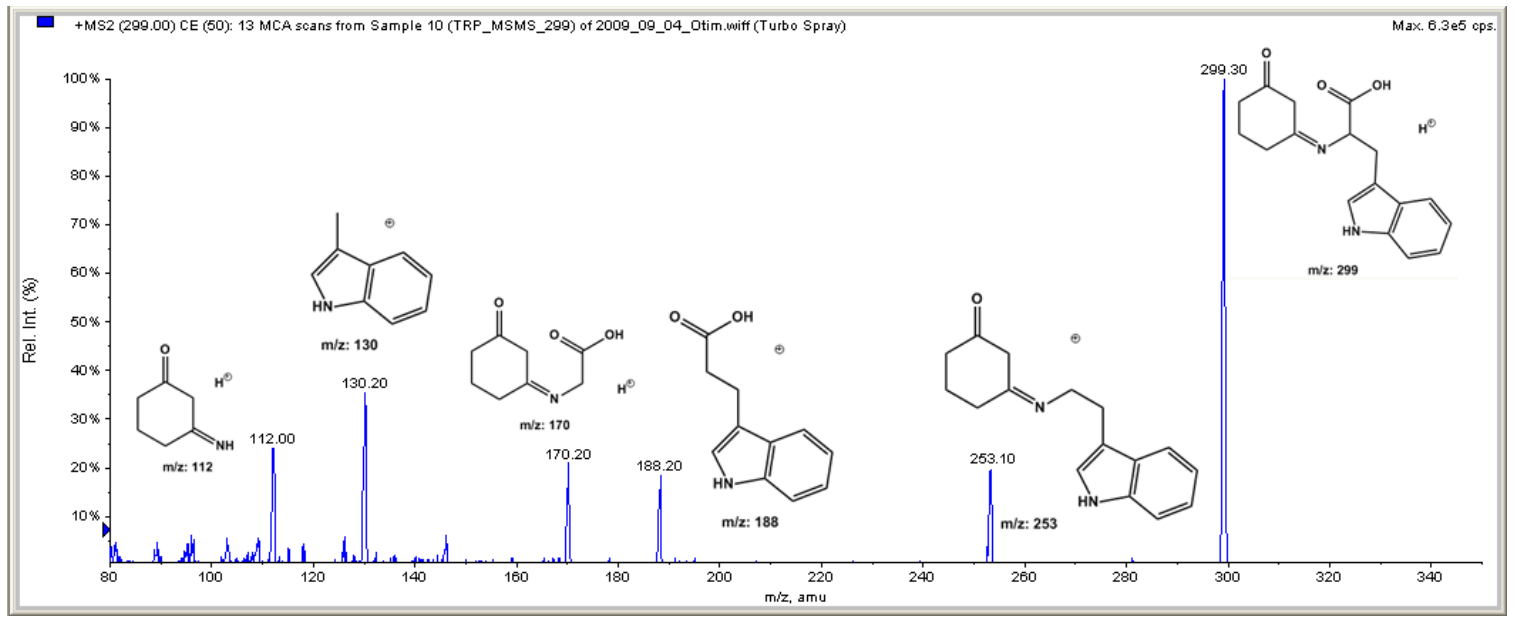

Figura 14: Espectro de massas da substância ácido 3-(1H-indol-3-il)-2-(3oxociclohexilideneamino)propanóico (3). 


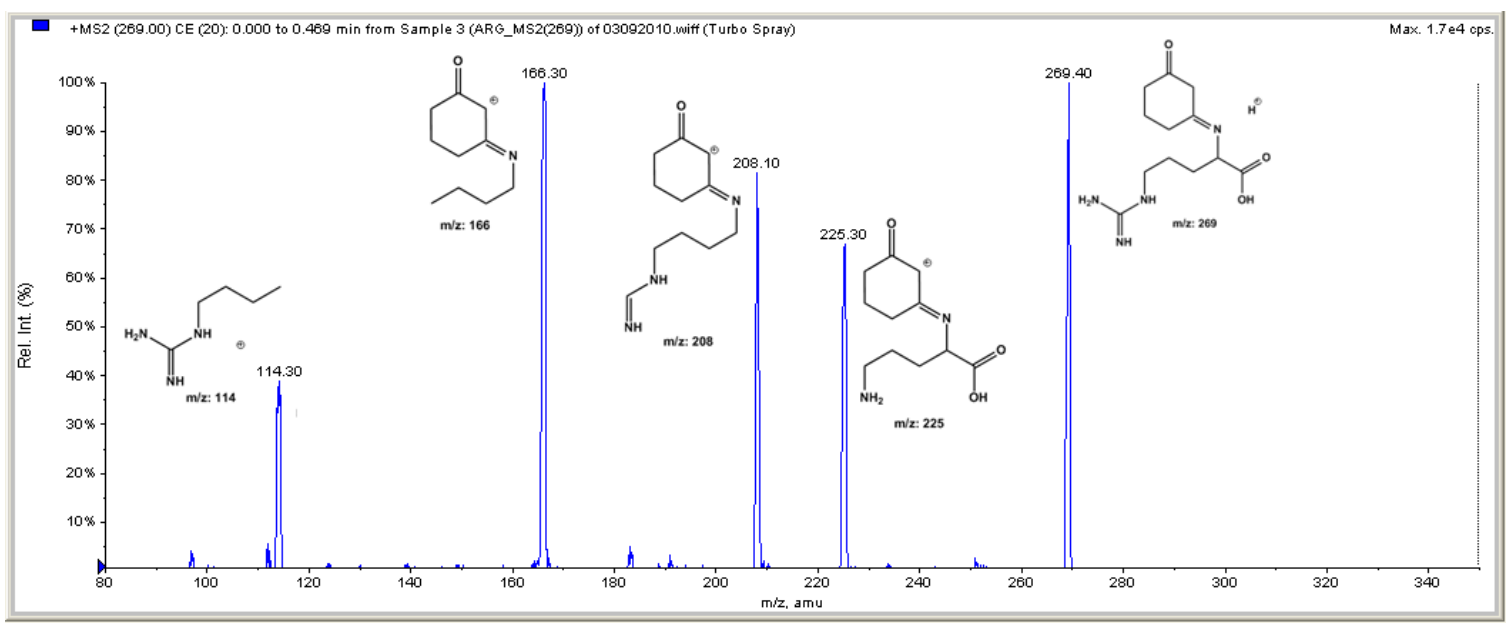

Figura 15: Espectro de massas da substância ácido 5-guanidino-2-(3oxociclohexilideneamino)pentanóico (4).

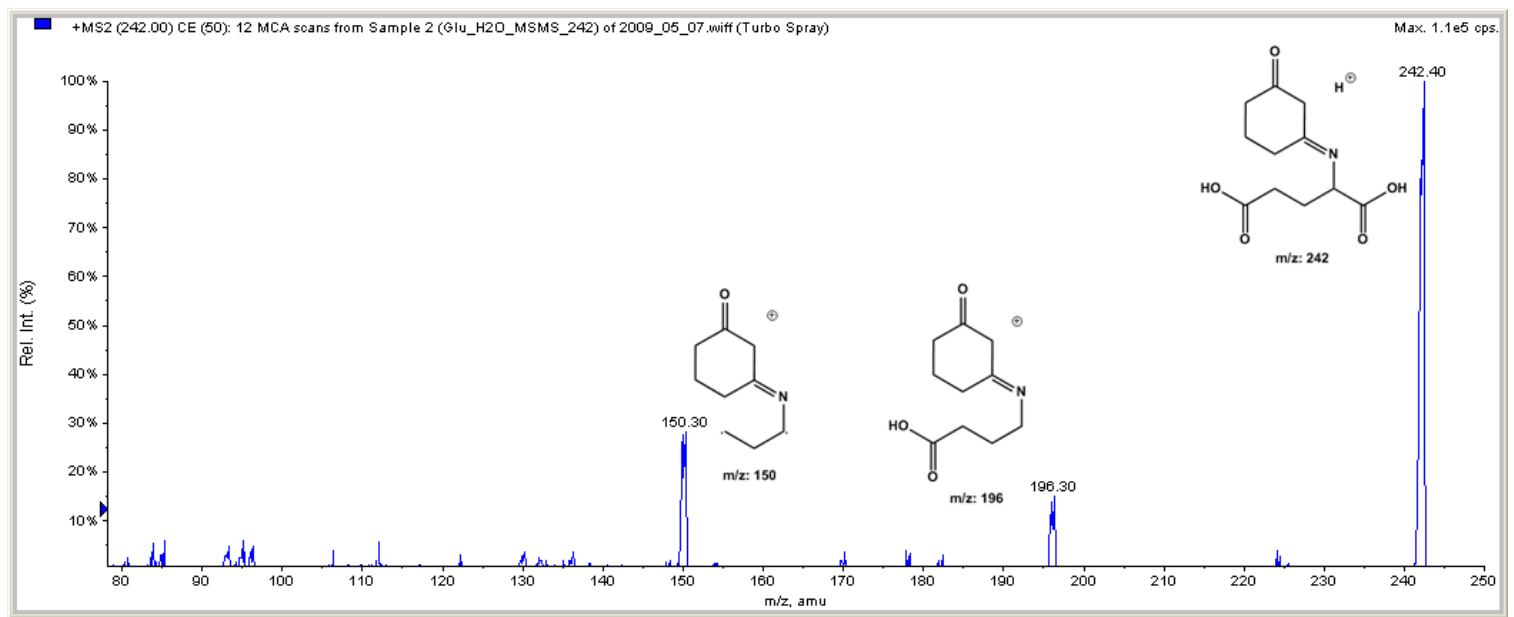

Figura 16: Espectro de massas da substância ácido 2-(3-oxociclohexilideneamino) pentanodióico (5). 


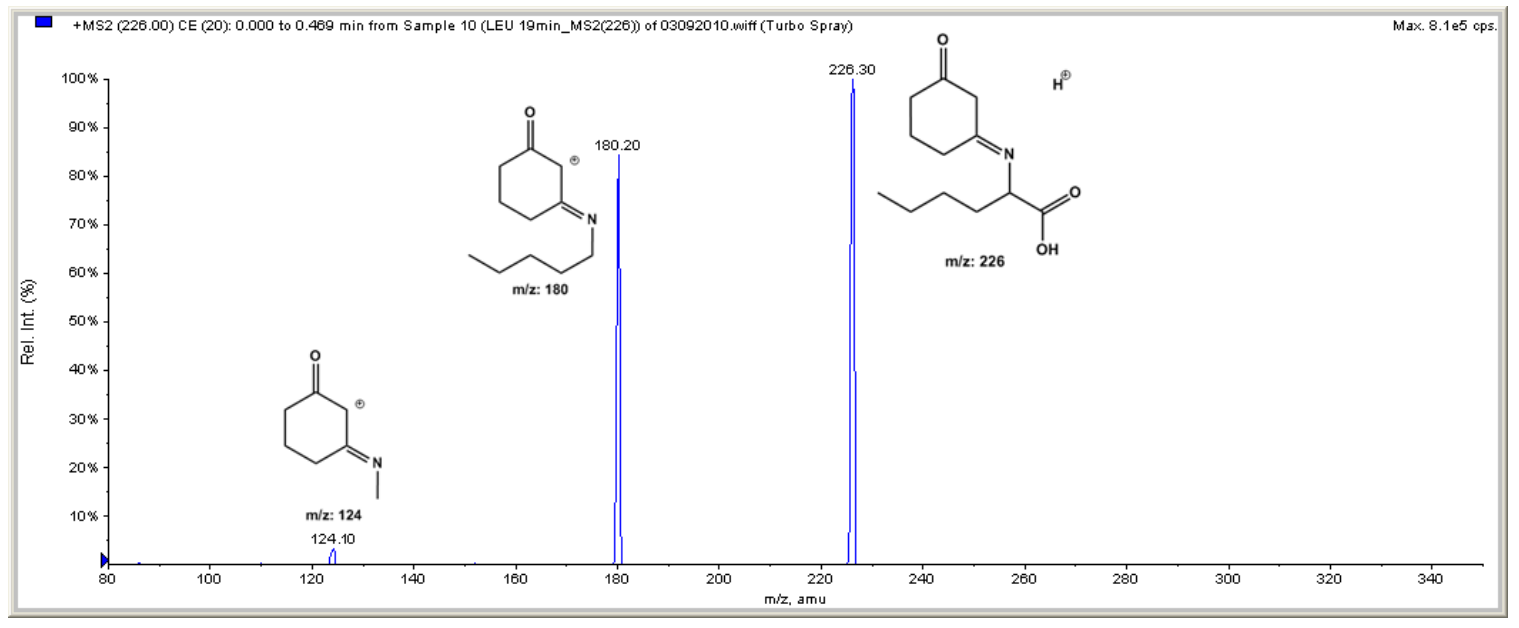

Figura 17: Espectro de massas da substância ácido 2-(3-oxociclohexilideneamino)hexanóico (6).

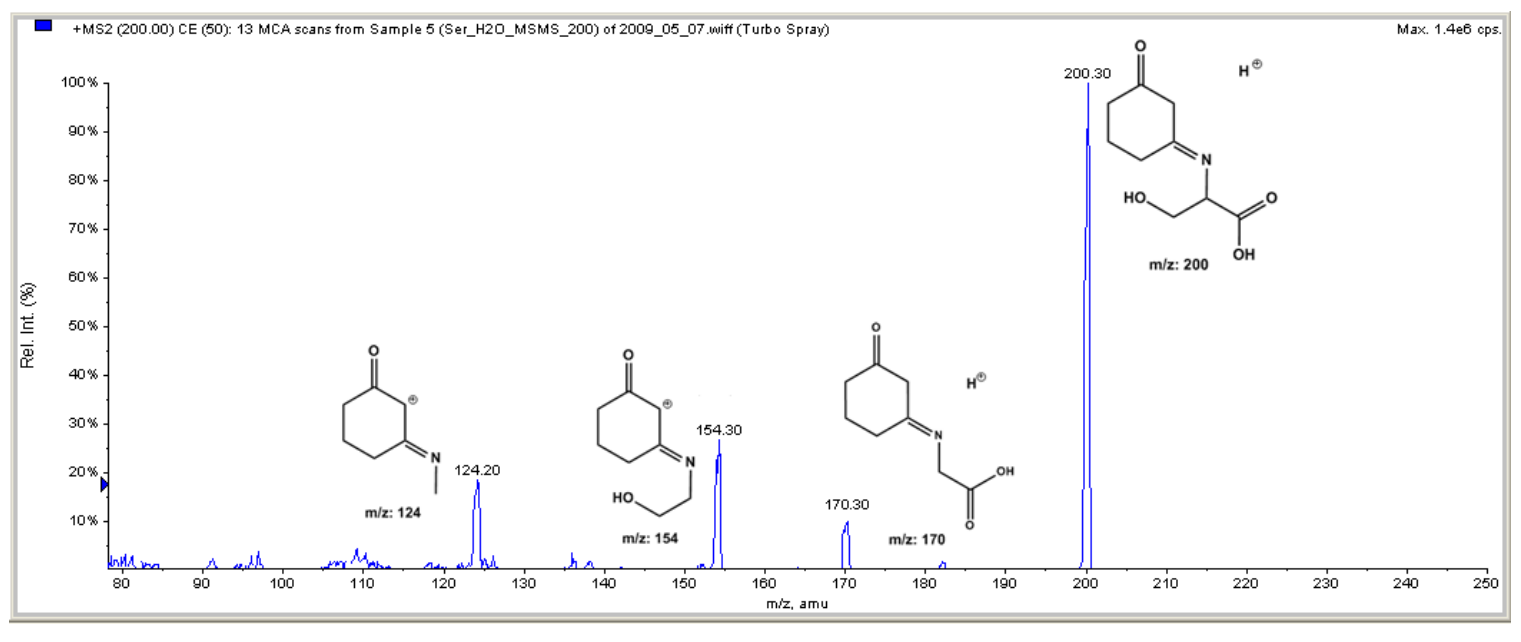

Figura 18: Espectro de massas da substância ácido 3-hidroxi-2-(3-oxociclohexili deneamino propanóico (7).

70 


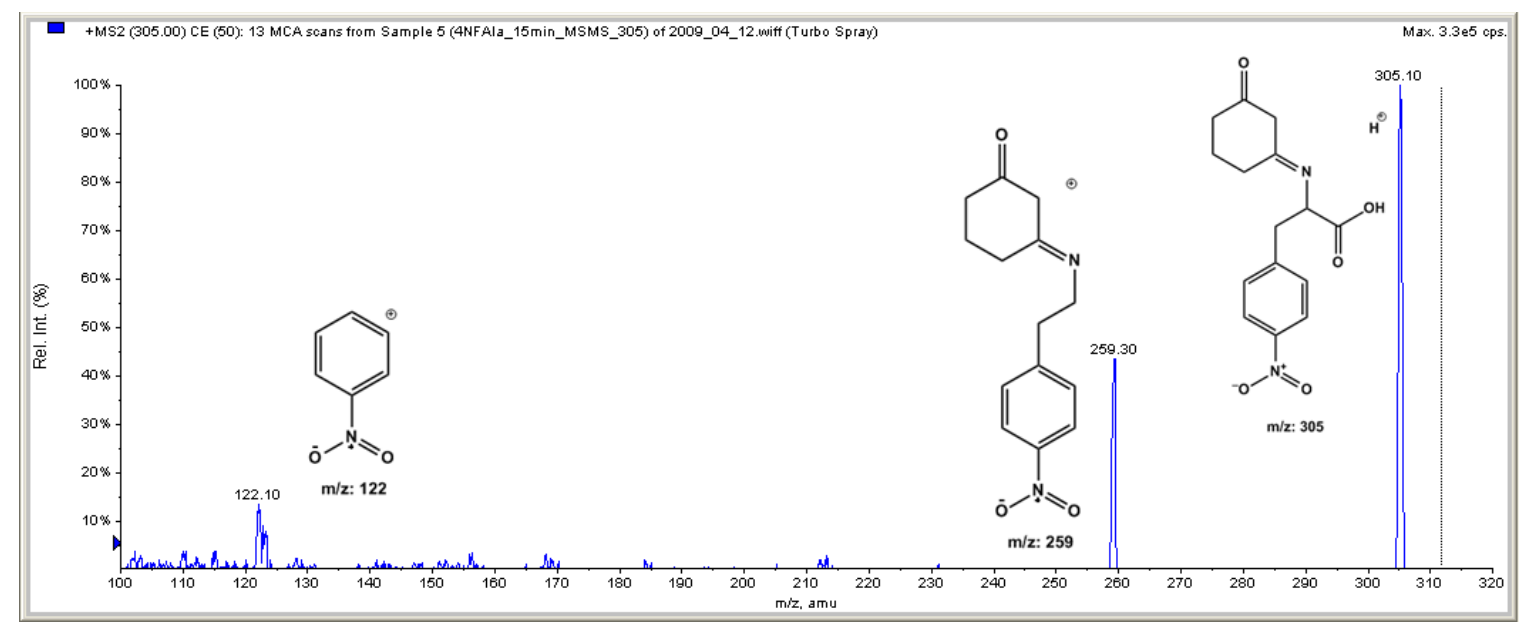

Figura 19: Espectro de massas da substância ácido 2-(4-nitrofenil)-2-(3oxociclohexilideneamino) acético (8).

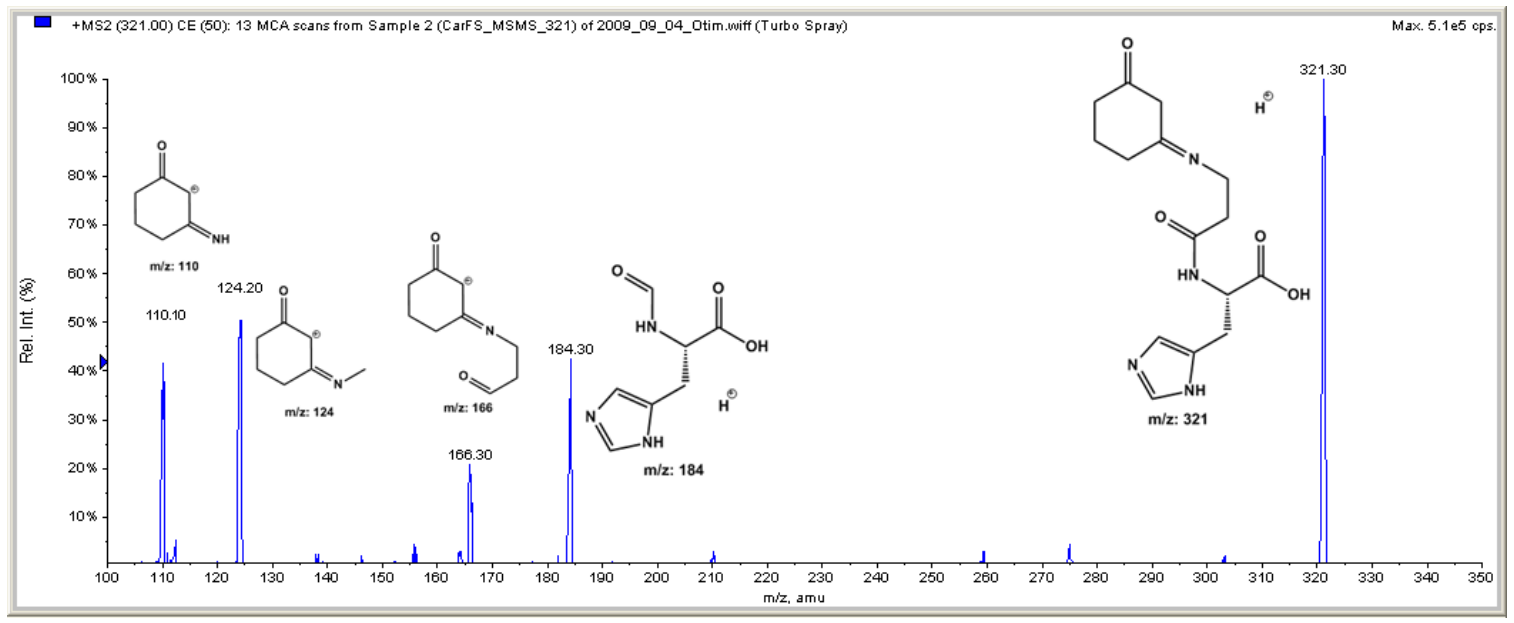

Figura 20: Espectro de massas da substância ácido 3-(1)-imidazol-5-il)-2-(3-(3oxociclohexilideneamino) propanamido)propanóico (9). 


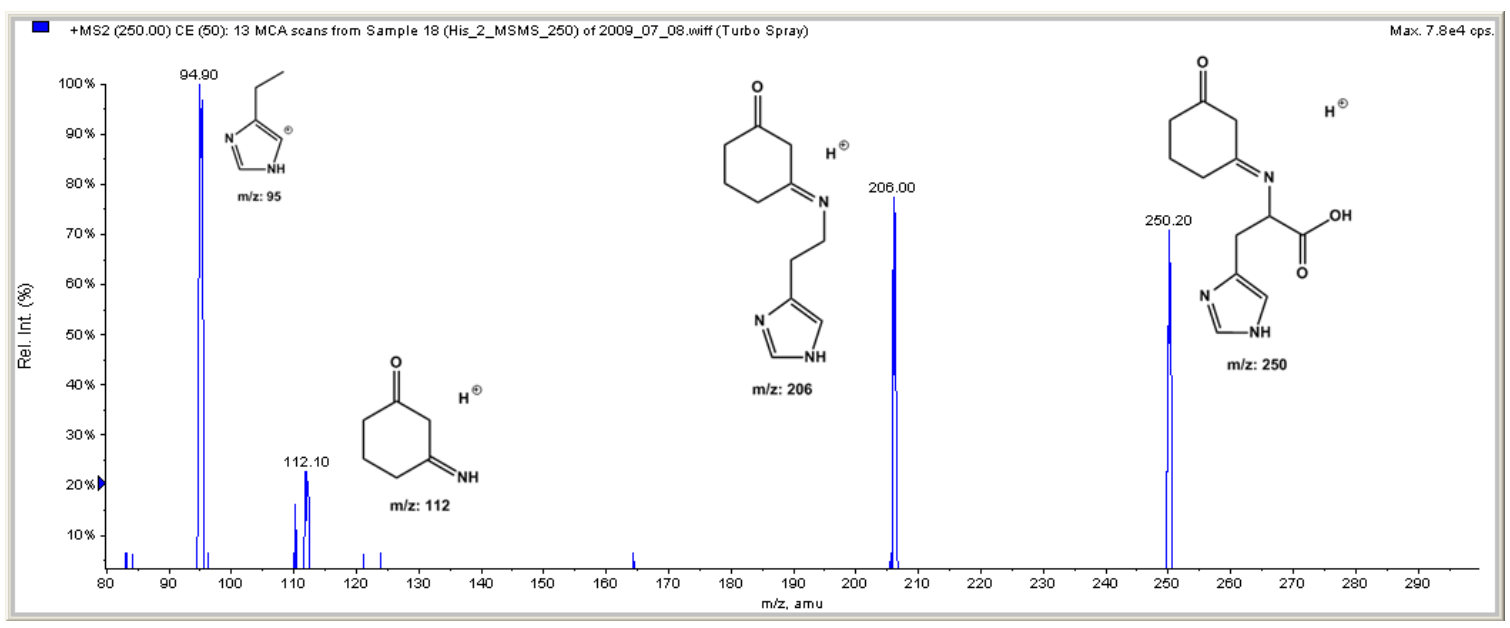

Figura 21: Espectro de massas da substância ácido 3-(1H-imidazol-4-il)-2-(3-oxociclohexilidene amino)propanóico (10).

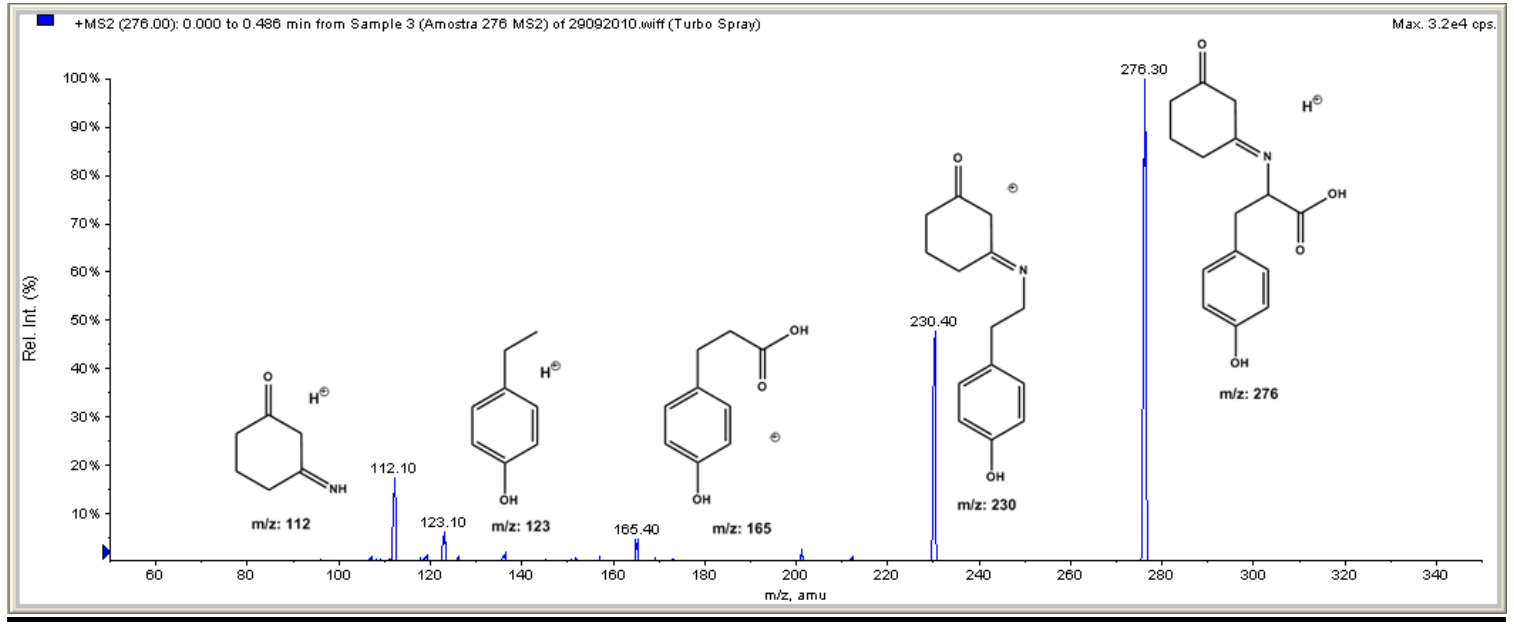

Figura 22: Espectro de massas da substância ácido 2-(4-hidroxifenil)-2-(3oxociclohexilideneamino) acético (11). 


\subsubsection{Ressonância Nuclear Magnética}

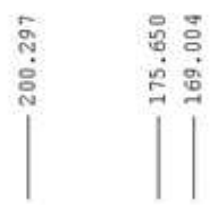<smiles>C[C@@H](N=C1CCCC(=O)C1)C(=O)O</smiles>

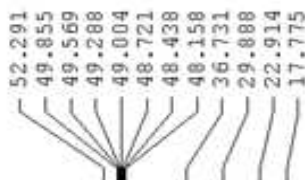

$\mathrm{MeOH}$

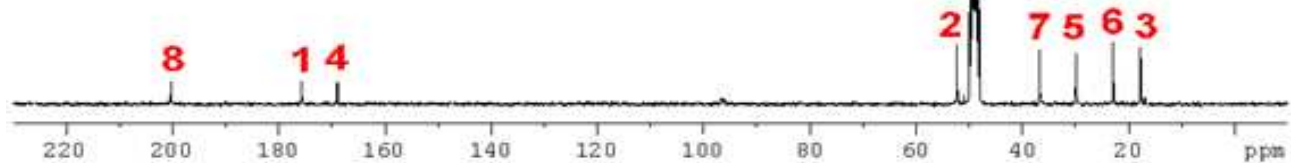

Figura 23: Espectro de $\mathrm{RMN}{ }^{13} \mathrm{C}$ do ácido 2-(3-oxociclohexilideneamino) propanóico (1). $\left(\mathrm{CD}_{3} \mathrm{OD}, 300 \mathrm{MHz}\right): \delta 17.77,22.91,29.88,36.73,52.29,169.00,175.65,200.29$;

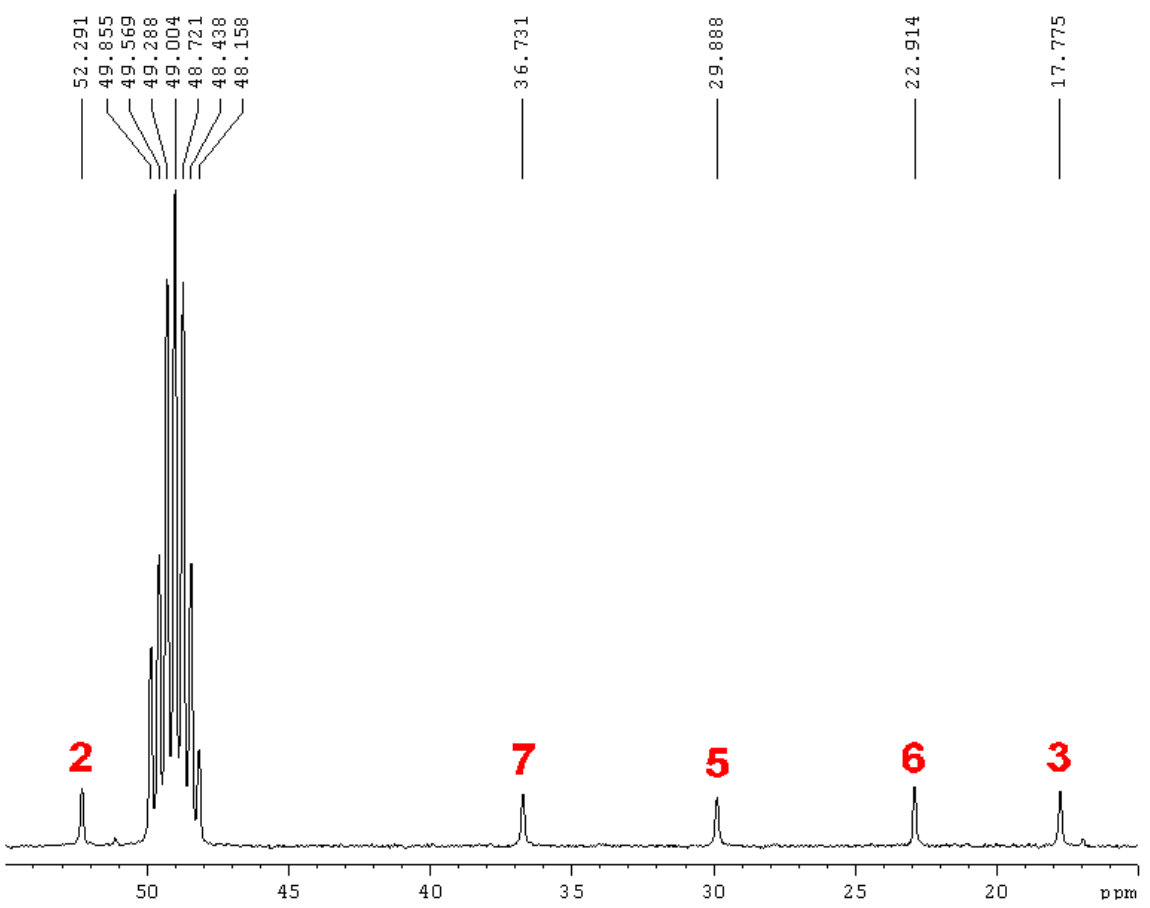

Figura 24: Zoom da região de 10 a 60 ppm do espectro mostrado na figura 23. 
<smiles>CC(N=C1CCCC(=O)C1)C(=O)O</smiles>
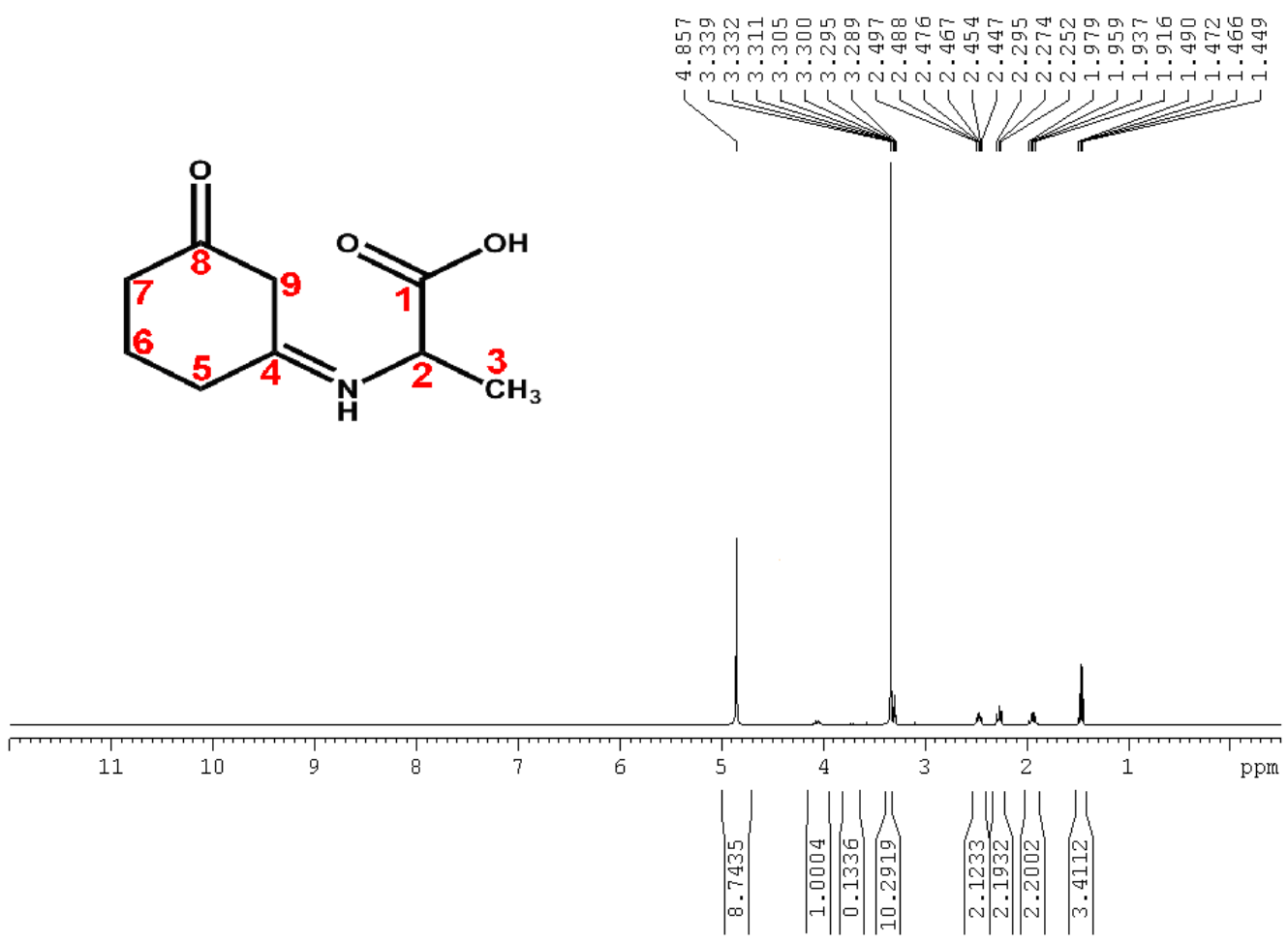

Figura 25: Espectro de RMN ${ }^{1} \mathrm{H}$ do ácido 2-(3-oxociclohexilideneamino) propanóico (1). ${ }^{1} \mathrm{H}$ NMR $\left(\mathrm{CD}_{3} \mathrm{OD}, 300 \mathrm{MHz}\right):$ $1.44-1.49(\mathrm{~d}, 3 \mathrm{H}), 1.91-1.97(\mathrm{~m}, 2 \mathrm{H}), 2.25-2.29(\mathrm{t}, 2 \mathrm{H}), 2.44-2.49(\mathrm{t}, 2 \mathrm{H}), 3.33(\mathrm{~s}$, $2 \mathrm{H}), 4.05-4,07(\mathrm{~m}, 1 \mathrm{H})$;

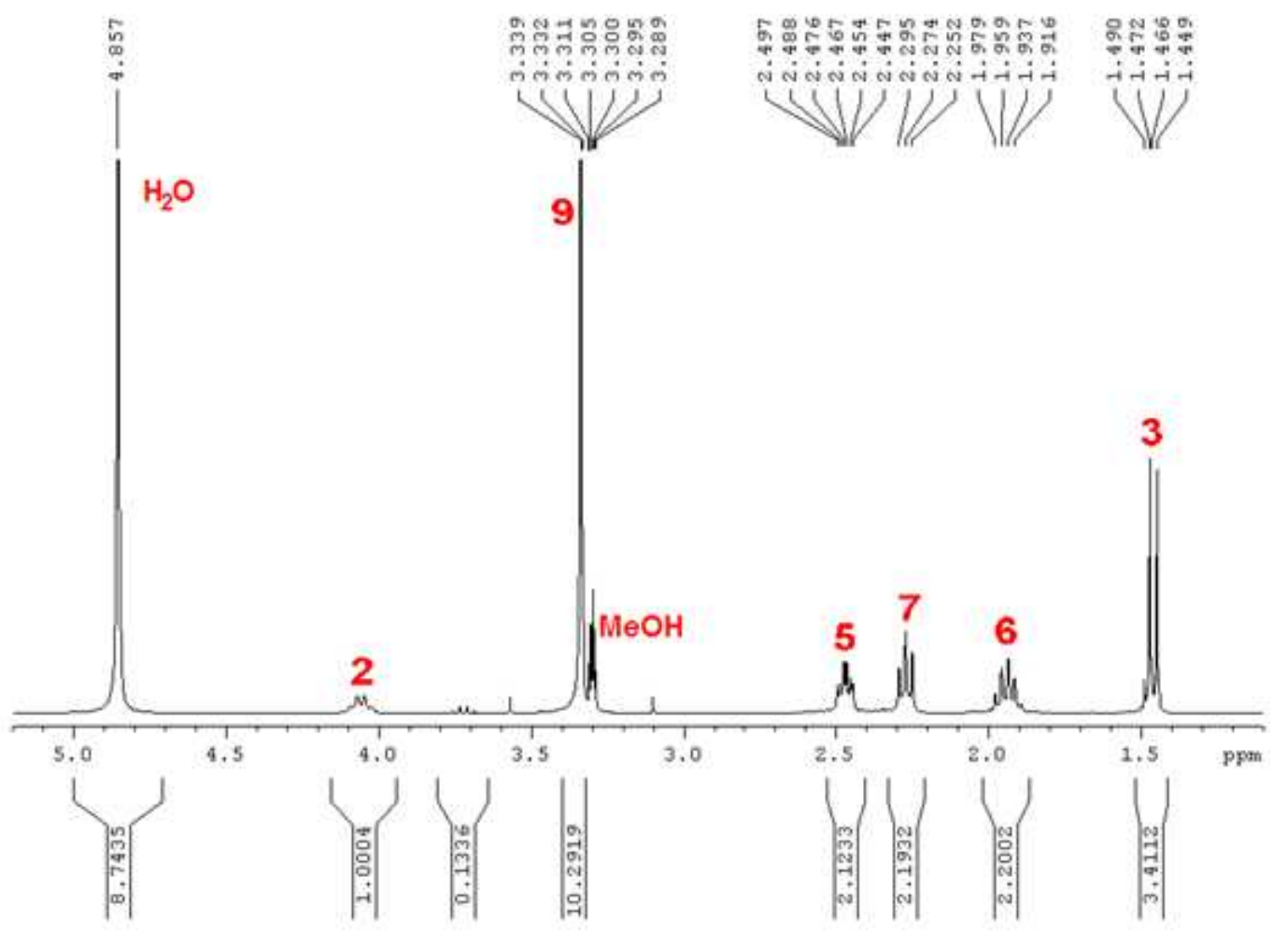

Figura 26: Zoom da região de 1 a 5.5 ppm do espectro mostrado na figura 25 . 


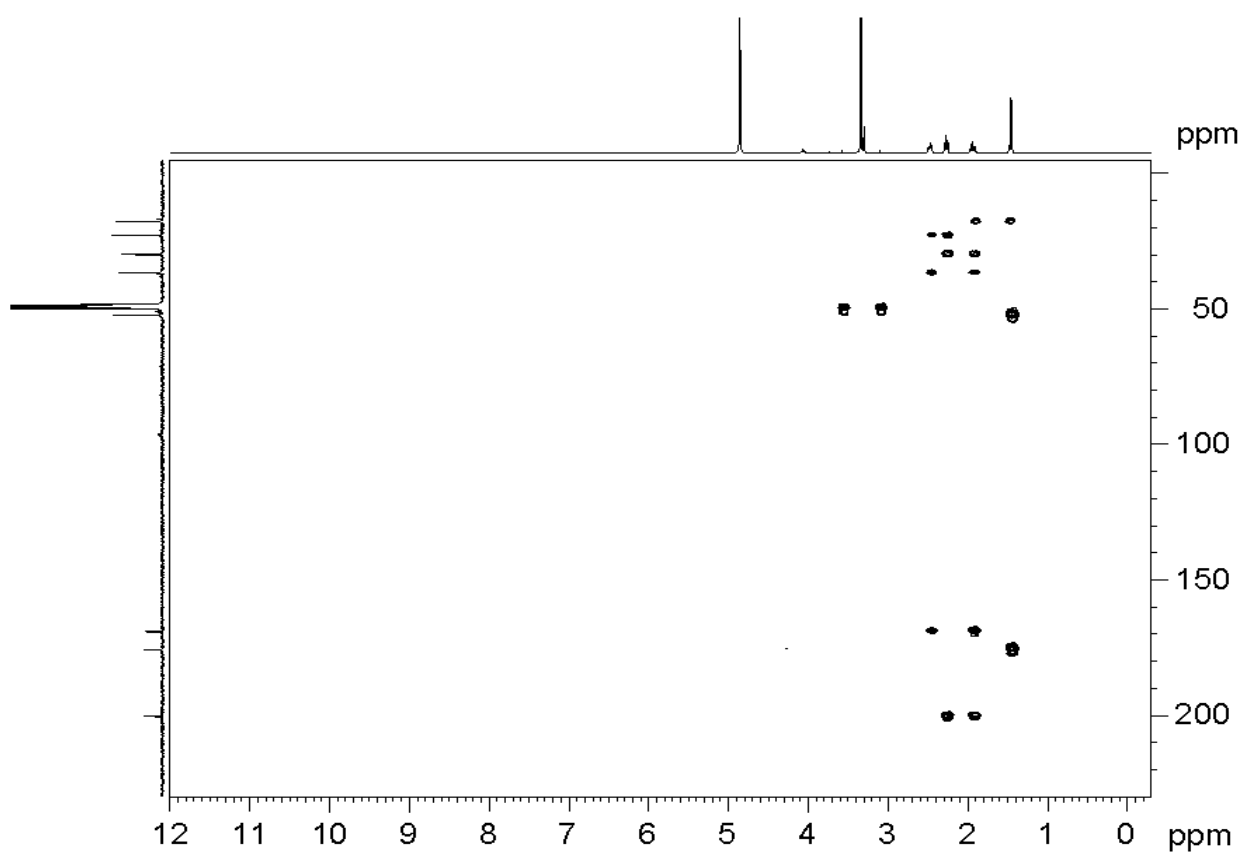

Figura 27: Espectro de RMN bidimensional $H M B C$ do ácido 2-(3-oxociclohexilideneamino) propanóico (1).

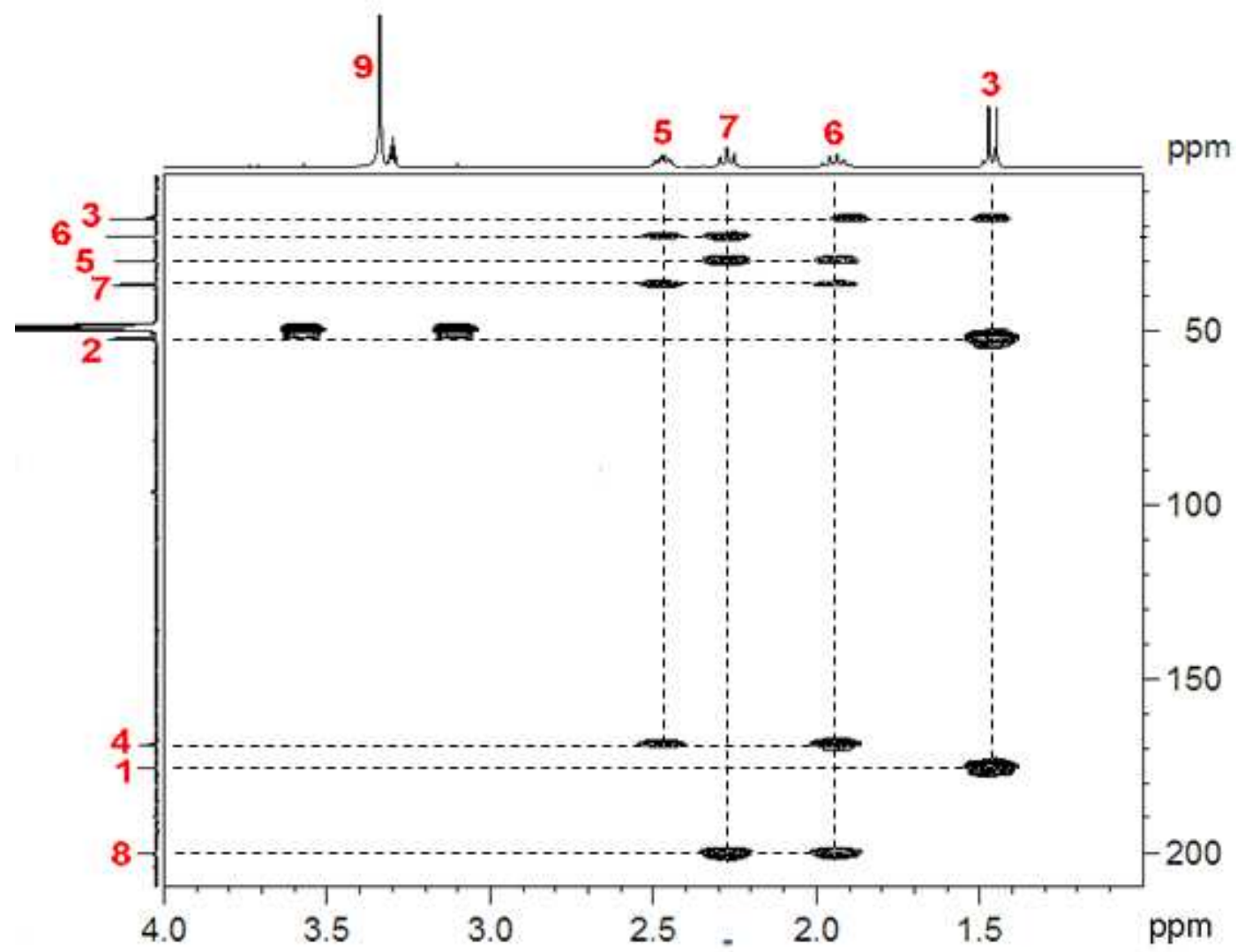

Figura 28: Zoom da região de 1 a 4 ppm, do eixo das abscissas, do espectro mostrado na figura 27. 
RMN do composto ácido 4-(metiltio)-2-(3-oxociclohexilideneamino)butanóico (2): ${ }^{1} \mathrm{H}\left(500 \mathrm{MHz}, \mathrm{D}_{2} \mathrm{O}\right) \delta: 3.52(\mathrm{~s}, 2 \mathrm{H}), 3.02-2.99(\mathrm{t}, 1 \mathrm{H}), 2.67-2.64(\mathrm{t}, 2 \mathrm{H}), 2.48-2.45(\mathrm{t}$, $2 \mathrm{H}), 2.34-2.32(\mathrm{t}, 2 \mathrm{H}), 2.18-2.13(\mathrm{~m}, 2 \mathrm{H}), 2.05(\mathrm{~s}, 3 \mathrm{H}), 1.95-1.89(\mathrm{~m}, 2 \mathrm{H}) .{ }^{13} \mathrm{C}(500$ $\left.\mathrm{MHz}, \mathrm{D}_{2} \mathrm{O}\right) \delta: 208.70,177.50,164.30,65.12,43.84,41.87,36.94,33.27,29.26$, $19.79,14.98$.

RMN do composto ácido 3-(1H-indol-3-il)-2-(3-oxociclohexilideneamino) propanóico (3): ${ }^{1} \mathrm{H}\left(500 \mathrm{MHz}, \mathrm{D}_{2} \mathrm{O}\right) \delta$ : 7.69-7.71 (d, $\left.1 \mathrm{H}\right), 7.51-7.52(\mathrm{~d}, 1 \mathrm{H}), 7.30(\mathrm{~s}$, $1 \mathrm{H})$, 7.24-7.27 (t, $1 \mathrm{H}), 7.15-7.18(\mathrm{t}, 1 \mathrm{H}), 4.02-4.04(\mathrm{~d}, 2 \mathrm{H}), 3.44-3.48(\mathrm{t}, 1 \mathrm{H}), 3.25-$ $3.30(\mathrm{t}, 2 \mathrm{H}), 2.20-2.25(\mathrm{~m}, 2 \mathrm{H}), 2.10(\mathrm{~s}, 2 \mathrm{H}), 1.87-1.89(\mathrm{t}, 2 \mathrm{H}) .{ }^{13} \mathrm{C}\left(500 \mathrm{MHz}, \mathrm{D}_{2} \mathrm{O}\right)$ $\delta: 202.70,177.30,164,50,139.12,129.44,127.87,124.94,122.27,121.26$, $114.79,110.27,67.85,43.39,41.84,36.69,31.19,20.09$.

RMN do composto ácido 5-guanidino-2-(3-oxociclohexilideneamino)pentanóico (4): ${ }^{1} \mathrm{H}\left(500 \mathrm{MHz}, \mathrm{D}_{2} \mathrm{O}\right) \delta: 7.92(\mathrm{~s}, 1 \mathrm{H}), 6.63(\mathrm{~s}, 2 \mathrm{H}), 3.48-3.46(\mathrm{t}, 1 \mathrm{H}), 3.32(\mathrm{~s}, 2 \mathrm{H})$, 2.79-2.74 (m, 2H), 2.42-2.39 (t, 2H), 2.26-2.22 (t, 2H), 2.00-1.97 (m, 2H), 1.76-1.72 $(\mathrm{t}, 1 \mathrm{H}), 1.60-1.57(\mathrm{~m}, 2 \mathrm{H}), 1.49-1.43(\mathrm{~m}, 2 \mathrm{H}) .{ }^{13} \mathrm{C}\left(500 \mathrm{MHz}, \mathrm{D}_{2} \mathrm{O}\right) \delta: 199.94$, 178.76, 164.19, 158.31, 66.14, 44.96, 42.61, 37.53, 34.27, 24.66, 19.37.

RMN do composto ácido 2-(3-oxociclohexilideneamino) pentanodióico (5): ${ }^{1} \mathrm{H}$ $\left(500 \mathrm{MHz}, \mathrm{D}_{2} \mathrm{O}\right) \delta: 3.51-3.48(\mathrm{t}, 1 \mathrm{H}), 3.39(\mathrm{~s}, 2 \mathrm{H}), 2.68-2.66(\mathrm{t}, 2 \mathrm{H}), 2.33-2.29(\mathrm{t}$, $2 \mathrm{H}), 2.27-2.25(\mathrm{t}, 2 \mathrm{H}), 1.97-1.93(\mathrm{~m}, 2 \mathrm{H}), 1.58-1.54(\mathrm{~m}, 2 \mathrm{H}) .{ }^{13} \mathrm{C}\left(500 \mathrm{MHz}, \mathrm{D}_{2} \mathrm{O}\right) \delta$ : 201.27, 179.47, 177.50, 164.26, 65.79, 45.36, 42.00, 39.09, 31.52, 27.61, 21.87.

RMN do composto ácido 2-(3-oxociclohexilideneamino)hexanóico (6): ${ }^{1} \mathrm{H}$ (500 $\left.\mathrm{MHz}, \mathrm{D}_{2} \mathrm{O}\right) \delta: 3.59(\mathrm{~s}, 2 \mathrm{H}), 2.52-2.51(\mathrm{t}, 2 \mathrm{H}), 2.31-2.31(\mathrm{t}, 2 \mathrm{H}), 2.15-2.14(\mathrm{t}, 1 \mathrm{H})$, 2.00-1.95 (m, 2H), 1.70-1.67 (m, 2H), 1.66-1.61 (m, 2H), 1.41-1.37 (m, 2H), 0.96$0.94(\mathrm{t}, 3 \mathrm{H}) .{ }^{13} \mathrm{C}\left(500 \mathrm{MHz}, \mathrm{D}_{2} \mathrm{O}\right) \delta: 200.21,178.35,164.70,67.65,43.66,42.14$, $38.27,30.99,30.05,24,23,20.87,16,02$.

RMN do composto ácido 3-hidroxi-2-(3-oxociclohexilideneamino) propanóico (7): ${ }^{1} \mathrm{H}\left(500 \mathrm{MHz}, \mathrm{D}_{2} \mathrm{O}\right) \delta: 3.97(\mathrm{~s}, 1 \mathrm{H}-\mathrm{OH}), 3.88-3.84(\mathrm{~m}, 2 \mathrm{H}), 3.66(\mathrm{~s}, 2 \mathrm{H}), 2.44-2.42(\mathrm{t}$, $2 \mathrm{H}), 2.37-2.35(\mathrm{t}, 2 \mathrm{H}), 1.99-1.96(\mathrm{~m}, 2 \mathrm{H}), 1.19-1.17(\mathrm{t}, 1 \mathrm{H}) .{ }^{13} \mathrm{C}\left(500 \mathrm{MHz}, \mathrm{D}_{2} \mathrm{O}\right) \delta$ : 203.75, 178.77, 173.41, 64.55, 63.02, 39.30, 39.14, 37.78, 23.11. 
RMN do composto ácido 2-(4-nitrofenil)-2-(3-oxociclohexilideneamino) acético (8): ${ }^{1} \mathrm{H}\left(500 \mathrm{MHz}, \mathrm{D}_{2} \mathrm{O}\right) \delta: 8.36-8.34(\mathrm{~d}, 2 \mathrm{H}), 7.65-7.64(\mathrm{~d}, 2 \mathrm{H}), 4.17-4.14(\mathrm{t}, 2 \mathrm{H})$, $3.77(\mathrm{~s}, 2 \mathrm{H}), 3.50-3.49(\mathrm{~d}, 2 \mathrm{H}), 3.47-3.44(\mathrm{t}, 2 \mathrm{H}), 3.40-3.36(\mathrm{~m}, 2 \mathrm{H}), 1.29-1.26(\mathrm{t}$, $1 \mathrm{H}) .{ }^{13} \mathrm{C}\left(300 \mathrm{MHz}, \mathrm{D}_{2} \mathrm{O}\right) \delta: 202.11,178.57,165.72,149.84,146.23,133.25$, $126.92,58.36,41.70,39.03,34.19,33.73,14.84$.

RMN do composto ácido 3-(1H-imidazol-5-il)-2-(3-(3-oxociclohexilideneamino) propanamido)propanóico (9): ${ }^{1} \mathrm{H}\left(500 \mathrm{MHz}, \mathrm{CD}_{3} \mathrm{OD}\right) \delta$ : 8.16-8.16 (d, $\left.1 \mathrm{H}\right), 8.06-$ $8.06(\mathrm{~d}, 1 \mathrm{H}), 7.04(\mathrm{~s}, 1 \mathrm{H}), 4.49-4.51(\mathrm{~m}, 1 \mathrm{H}), 3,34(\mathrm{~s}, 2 \mathrm{H}), 3.16-3.19(\mathrm{t}, 2 \mathrm{H}), 3.02-$ $3.05(\mathrm{~d}, 2 \mathrm{H}), 2.58-2.63(\mathrm{~m}, 2 \mathrm{H}), 2.38-2.41(\mathrm{t}, 2 \mathrm{H}), 2.25-2.27(\mathrm{t}, 2 \mathrm{H}), 1.89-1.92(\mathrm{t}$, 2H). ${ }^{13} \mathrm{C}\left(300 \mathrm{MHz}, \mathrm{CD}_{3} \mathrm{OD}\right) \delta: 200.03,177.05,172.73,169.42,135.14,133.71$, $118.50,55.42,40.03,37.36,35.37,33.48,30.03,29.57,22.97$.

RMN do composto ácido 3-(1H-imidazol-4-il)-2-(3-oxociclohexilidene amino)propanóico (10): ${ }^{1} \mathrm{H}\left(500 \mathrm{MHz}, \mathrm{D}_{2} \mathrm{O}\right) \delta$ : 8.63-8.63 (d, $\left.1 \mathrm{H}\right), 7.39-7.38(\mathrm{~d}, 1 \mathrm{H})$, 4.05-4.03 (t, $1 \mathrm{H}), 3.39(\mathrm{~s}, 2 \mathrm{H}), 3.18-3.16(\mathrm{~d}, 2 \mathrm{H}), 3.15-3.13(\mathrm{t}, 2 \mathrm{H}), 2.49-2.46(\mathrm{t}$, $2 \mathrm{H}), 2.29-2.27(\mathrm{~m}, 2 \mathrm{H}) .{ }^{13} \mathrm{C}\left(500 \mathrm{MHz}, \mathrm{D}_{2} \mathrm{O}\right) \delta: 204.00,178.95,172.77,137.21$, $132.21,120.56,59.76,37.80,35.40,31.74,29.92,14.06$.

RMN do composto ácido 2-(4-hidroxifenil)-2-(3-oxociclohexilideneamino) acético (11): ${ }^{1} \mathrm{H}\left(500 \mathrm{MHz}, \mathrm{D}_{2} \mathrm{O}\right) \delta: 7.68(\mathrm{~s}, 1 \mathrm{H}-\mathrm{OH}), 7.20-7.18(\mathrm{~d}, 1 \mathrm{H}), 7.17-7.15(\mathrm{~d}, 1 \mathrm{H})$, 6.91-6.89 (d, 1H), 6.85-6.83 (d, $1 \mathrm{H}), 3.59(\mathrm{~s}, 2 \mathrm{H}), 3.19-3.18(\mathrm{~d}, 2 \mathrm{H}), 3.08-3.06(\mathrm{t}$, $2 \mathrm{H}), 2.46-2.43(\mathrm{t}, 2 \mathrm{H}), 2.42-2.39(\mathrm{~m}, 2 \mathrm{H}), 1.36-1.39(\mathrm{t}, 1 \mathrm{H}) .{ }^{13} \mathrm{C}\left(500 \mathrm{MHz}, \mathrm{D}_{2} \mathrm{O}\right) \delta$ : $202.55,188.44,176.88,157.71,133.40,130.97,129.78,118.71,118.20,62.32$, $39.51,38.50,37.67,36.85,23.56$.

A partir da análise dos espectros de massas e RMN, podemos confirmar a obtenção das diferentes estruturas propostas, sendo constituído assim, um primeiro passo na obtenção sintética de micosporinas. 


\subsection{ANÁLISE DAS PROPRIEDADES MOLECULARES}

\subsubsection{Determinação do Espectro de Absorção de UV}

Os espectros de absorção na região do UV (190 a $400 \mathrm{~nm}$ ) dos compostos sintetizados, a uma concentração de $0,5 \mathrm{mg} / \mathrm{mL}$ estão demonstrados na figura 29. No canto esquerdo superior de cada espectro estão indicados os comprimentos de onda em que ocorreram as máximas absorções das substâncias testadas. Em alguns casos, a molécula testada apresentou mais de um comprimento de onda com absorção máxima.

$\mathrm{Na}$ tabela 6 estão demonstrados os comprimentos de onda $(\lambda)$ nos quais as 10 substâncias testadas tiveram sua máxima absorção, relacionados às respectivas intensidades de cada absorção. Os compostos AM-4-n-Phe, AM-Car, AM-His e AM-Trp, apresentaram dois comprimentos de onda com picos de máxima absorção, enquanto os outros compostos apresentaram somente um pico. 

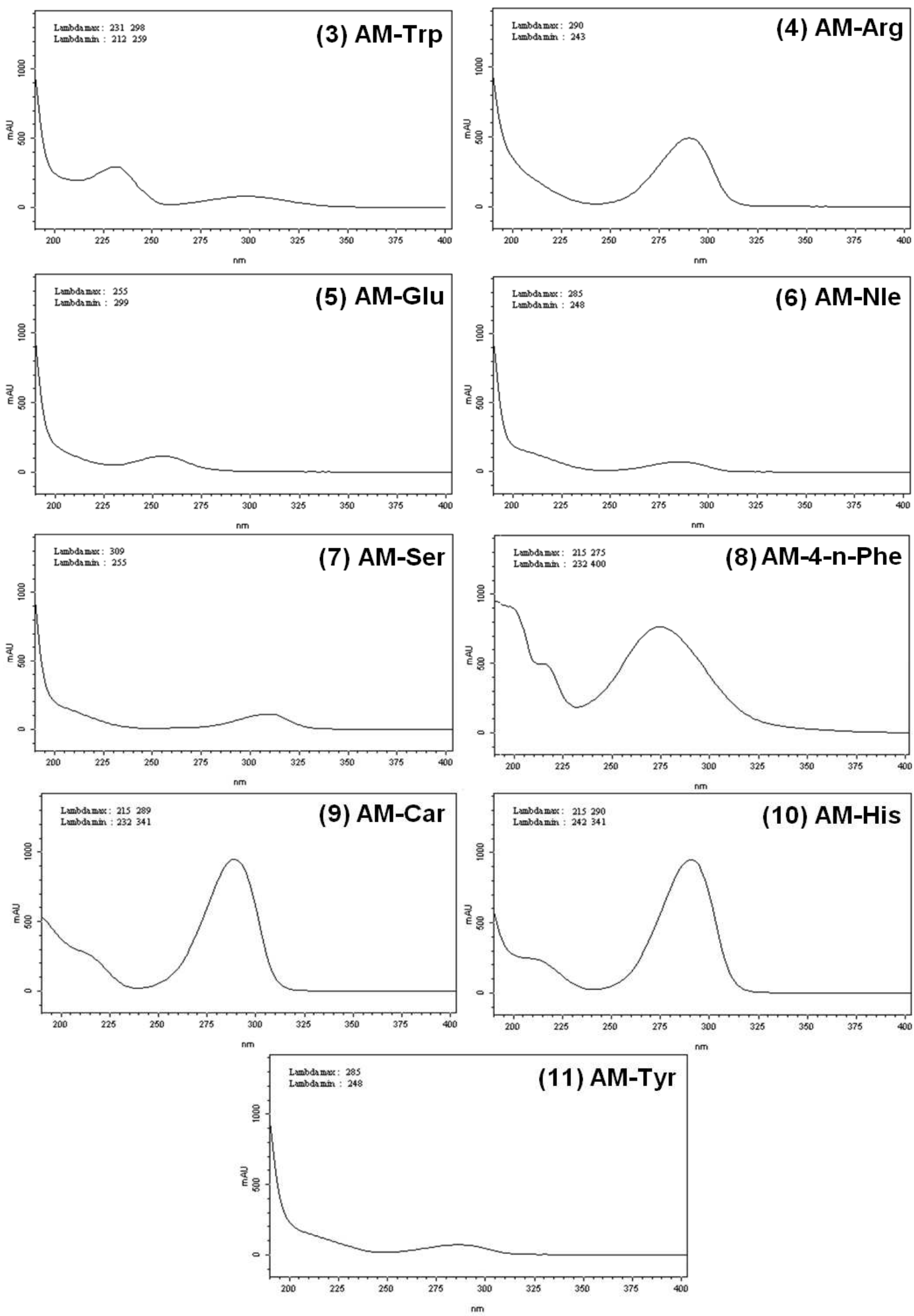

Figura 29: Espectros de absorção de radiação ultravioleta obtidos nas análises dos análogos AMTrp, AM-Arg, AM-Glu, AM-Nle, AM-Ser, AM-4-n-Phe, AM-Car, AM-His e AM-Tyr. O eixo das abscissas demonstra os comprimentos de onda compreendidos entre 190 e $400 \mathrm{~nm}$ e o eixo das ordenadas, a intensidade da absorção. 


\begin{tabular}{cc}
\hline Substância & $\lambda$ máx $(\mathrm{nm})$ \\
\hline AM-4-n-Phe* & 215 \\
\hline AM-Arg & 275 \\
AM-Car* & 290 \\
& 215 \\
AM-Glu & 289 \\
AM-His* & 255 \\
\hline AM-Nle & 215 \\
AM-Ser & 290 \\
AM-Tyr & 285 \\
AM-Trp* & 309 \\
& 285 \\
\hline
\end{tabular}

Tabela 6: Comprimentos de onda ( $\lambda$ máx) com absorções máximas dos compostos AM-Trp, AMArg, AM-Glu, AM-Nle, AM-Ser, AM-4-n-Phe, AM-Car, AM-His e AM-Tyr. *compostos que apresentaram dois $\lambda$ máx.

\subsubsection{Determinação do Coeficiente de Extinção Molar}

Para determinar os coeficientes de extinção molar, as soluções aquosas das substâncias, tiveram suas absorbâncias determinadas no espectrofotômetro UV Shimadzu(C UV-1650PC, nos comprimentos de onda em que cada substância obtida teve sua máxima absorbância. As concentrações utilizadas variaram de 0,3 a 3,3 mM, pois concentrações mais altas acabaram ultrapassando o máximo valor de absorbância. Contudo, este fato não interferiu na determinação, uma vez que o coeficiente é proporcional à concentração utilizada. As leituras foram realizadas em cubetas de quartzo, com um volume de $3 \mathrm{~mL}$ e caminho ótico de $1 \mathrm{~cm}$.

Os resultados dos coeficientes de extinção molar (demonstrados na tabela 7) obtidos nas análises das substâncias variaram entre 170 (AM-4-n-Phe) e 6000 $\mathrm{M}^{-1} \mathrm{~cm}^{-1}$ (AM-Car), valores muito baixos se comparados aos coeficientes das micosporinas, que variam entre 28000 e $50000 \mathrm{M}^{-1} \mathrm{~cm}^{-1}$ (Conde et al., 2000), ou de 
substâncias utilizadas em composições fotoprotetoras que possuem um coeficiente acima de $35000 \mathrm{M}^{-1} \mathrm{~cm}^{-1}$ (Nazeeruddin et al., 2007).

\begin{tabular}{|c|c|c|c|}
\hline Substância & [ M ] & Abs & $\varepsilon$ \\
\hline AM-4-n-Phe & 0,00184 & 0,316 & 172,1 \\
\hline AM-Arg & 0,00095 & 0,276 & 285,9 \\
\hline AM-Car & 0,00021 & 1,269 & 6011,1 \\
\hline AM-Glu & 0,00017 & 0,123 & 718,4 \\
\hline AM-His & 0,00105 & 1,742 & 1654,8 \\
\hline AM-Nle & 0,00111 & 0,806 & 722,2 \\
\hline AM-Ser & 0,00302 & 0,994 & 328,6 \\
\hline AM-Tyr & 0,00109 & 0,67 & 610,3 \\
\hline AM-Trp & 0,00091 & 1,092 & 1201,6 \\
\hline
\end{tabular}

Tabela 7: Valores do coeficiente de absortividade $(\varepsilon)$ obtidos para os análogos, de acordo com a lei de Beer-Lambert.

A análise destes dados, conjuntamente com os dados obtidos na determinação do espectro de absorção de UVR, demonstra que as substâncias obtidas não conseguiram assimilar as propriedades fotoprotetoras observada nas MAA, pois os compostos não apresentaram absorção na região do UVA (320 a $400 \mathrm{~nm}$ ), tampouco demonstraram a propriedade de absorver altas quantidades de radiação. 


\subsubsection{Determinação de Potencial Antioxidante}

\subsubsection{Atividade sequestrante de radicais DPPH}

Para grau de comparação com os compostos sintetizados, utilizou-se ácido gálico, conhecido por sua propriedade antioxidante, como controle positivo nas mesmas concentrações. Os resultados obtidos estão demonstrados em concentração massa/volume na tabela 8 e relacionados em concentração molar na figura 30.

\begin{tabular}{|c|c|c|c|c|c|}
\hline$\left[\mu \mathrm{g} \cdot \mathrm{mL}^{-1}\right]$ & AM-Ser & AM-Car & AM-Arg & AM-Trp & AM-His \\
\hline 31,75 & $11,60 \pm 2,56$ & $4,08 \pm 6,13$ & $31,06 \pm 5,99$ & $24,18 \pm 3,68$ & $25,9 \pm 2,21$ \\
\hline 62,5 & $25,47 \pm 4,34$ & $10,82 \pm 2,39$ & $32,04 \pm 2,02$ & $27,58 \pm 4,86$ & $29,16 \pm 1,74$ \\
\hline 125 & $30,12 \pm 4,34$ & $11,65 \pm 7,63$ & $41,65 \pm 4,32$ & $32,53 \pm 3,89$ & $36,68 \pm 2,98$ \\
\hline 250 & $30,81 \pm 2,73$ & $22,45 \pm 6,59$ & $43,75 \pm 5,92$ & $41,73 \pm 5,76$ & $44,6 \pm 0,14$ \\
\hline 500 & $37,36 \pm 2,47$ & $43,74 \pm 4,19$ & $49,06 \pm 4,12$ & $54,47 \pm 3,35$ & $46,36 \pm 3,51$ \\
\hline
\end{tabular}

\begin{tabular}{|c|c|c|c|c|c|}
\hline$\left[\mu \mathrm{g} \cdot \mathrm{mL}^{-1}\right]$ & AM-Glu & AM-Tyr & AM-Nle & AM-4-n-Phe & Ác. gálico \\
\hline 31,75 & $12,63 \pm 6,49$ & $8,95 \pm 3,32$ & $18,39 \pm 8,74$ & $3,18 \pm 3,96$ & $95,89 \pm 0,56$ \\
\hline 62,5 & $13,94 \pm 4,64$ & $19,04 \pm 3,38$ & $23,52 \pm 8,82$ & $2,39 \pm 3,90$ & $95,00 \pm 0,26$ \\
\hline 125 & $18,10 \pm 6$ & $29,33 \pm 3,38$ & $24,23 \pm 9,31$ & $14,4 \pm 6$ & $94,92 \pm 0,36$ \\
\hline 250 & $19,36 \pm 7,42$ & $39,13 \pm 3,15$ & $34,02 \pm 8,29$ & $20,69 \pm 6,41$ & $95,89 \pm 0,21$ \\
\hline 500 & $22,5 \pm 1,77$ & $51,71 \pm 3,56$ & $32,04 \pm 8,55$ & $23,11 \pm 7,88$ & $93,99 \pm 0,21$ \\
\hline
\end{tabular}

Tabela 8: Percentuais de inibição de formação do radical DPPH dos diferentes compostos testados (AM-Glu, AM-Ser, AM-Car, AM-Arg, AM-His, AM-Trp, AM-Tyr, AM-4-n-Phe, AM-Nle e o controle positivo ácido Gálico) de acordo com a concentração final de cada composto em [ $\mu \mathrm{g} . \mathrm{mL}-1]$. Dados apresentados como \% de inibição \pm desvio padrão. 


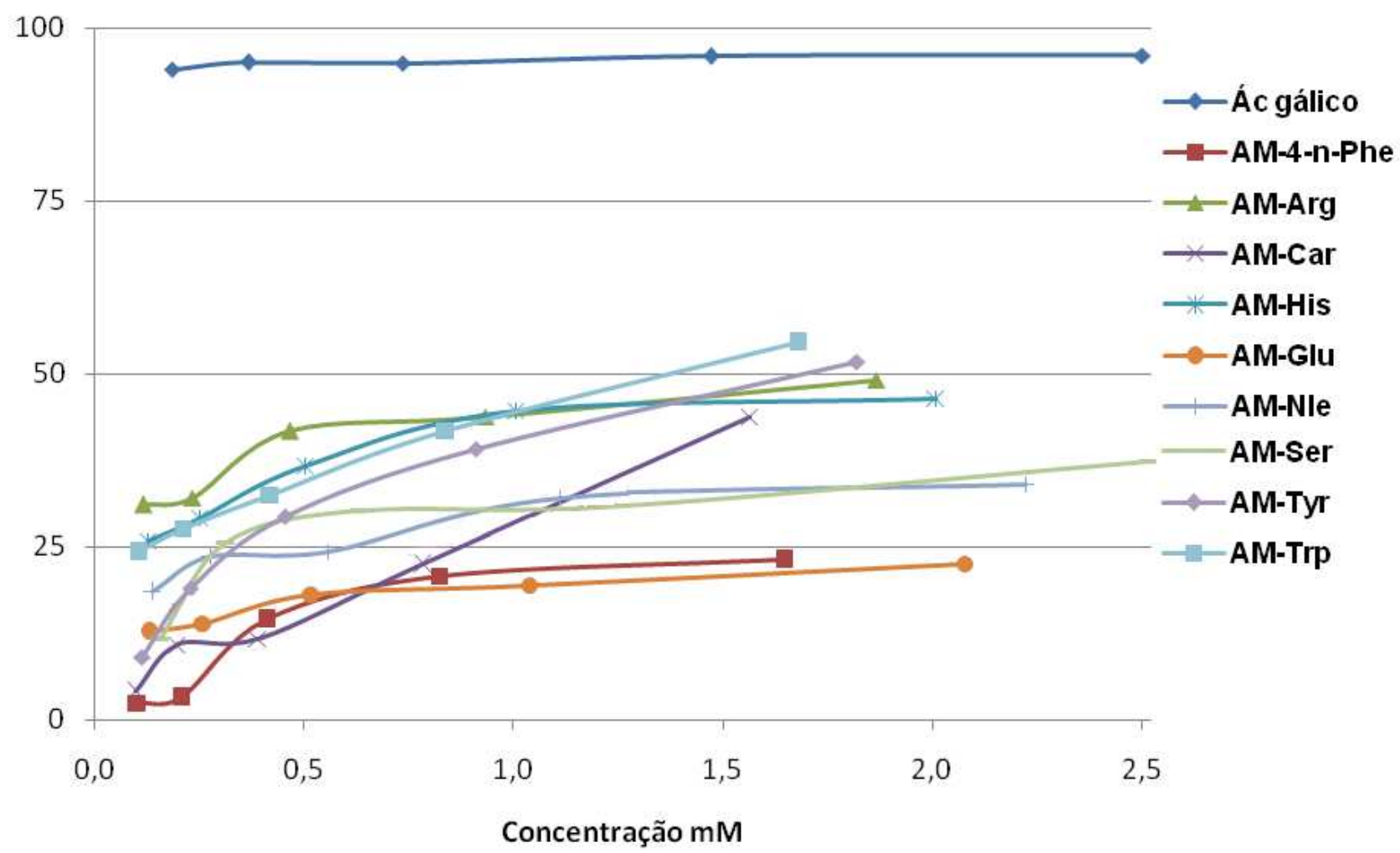

Figura 30: Dados de porcentagem de inibição da formação do radical DPPH pelos compostos, AM-Glu, AM-Ser, AM-Car, AM-Arg, AM-His, AM-Trp, AM-Tyr, AM-4-n-Phe, AM-Nle e o controle positivo ácido Gálico. Dados relacionando percentual de inibição no eixo $Y$ com concentração utilizada no eixo $X$.

A partir da análise da figura gerada, podemos observar que todos os compostos apresentam uma moderada atividade antioxidante de acordo com a metodologia de DPPH, ocasionando um decréscimo na redução desta molécula. Em dois dos compostos testados, AM-Trp e AM-Tyr, foi obtida a $I C_{50}$ em concentrações de 1,597 e 1,387 mM (0,410 e 0,470 mg. $\left.\mathrm{mL}^{-1}\right)$, respectivamente; contudo, podemos notar um padrão de crescimento em quase todas as substâncias até a última concentração testada Como se pode observar, o ácido gálico, apresentou uma inibição > 95\%, a partir da primeira concentração testada, confirmando assim a eficácia do teste realizado.

O ensaio de determinação de potencial antioxidante de determinadas moléculas ou extratos pelo método de DPPH possui a grande vantagem de ser um método simples, prático e ao mesmo tempo economicamente viável (Brand- 
Williams et al., 1995). Atualmente vem sendo usado por diversos grupos que estudam substâncias antioxidantes (Yokozawa et al., 1998; Ferreres et al., 2006; Kumaran e Karunakaran, 2006; Oliveira et al., 2009) pelo fato de ser um método facilmente estabelecido na rotina laboratorial, além de ser preciso e facilmente reprodutível (Deng et al., 2010). Entretanto, assim como qualquer técnica, essa metodologia requer alguns cuidados básicos na sua execução. Um dos problemas que pode comprometer a técnica é o fato de a coloração produzida pela redução da molécula não ser estável por grandes períodos de tempo, podendo levar a uma avaliação errônea se a absorbância não for mensurada rapidamente. Outro ponto que deve ser levado em conta está relacionado à restrição do método, que simplesmente avalia o potencial redutor da substância antioxidante (BrandWilliams et al., 1995), sendo importante, sempre que possível, aliar outras metodologias para se determinar o real potencial antioxidante das estruturas em questão.

\subsubsection{Atividade sequestrante de radical superóxido $\left(\mathrm{O}_{2}{ }^{\circ-}\right)$}

$\mathrm{Na}$ avaliação da atividade sequestrante de radicais superóxido, novamente foi utilizado ácido gálico como controle positivo reacional. Os resultados obtidos através desta técnica estão demonstrados na tabela 9 e relacionados na figura 31.

\begin{tabular}{c||ccccc}
{$\left[\mu \mathrm{g} \cdot \mathrm{mL}^{-1}\right]$} & AM-Ser & AM-Car & AM-Arg & AM-Trp & AM-His \\
\hline \hline $\mathbf{2 0}$ & $18,52 \pm 0,02$ & $8,85 \pm<0,01$ & $23,79 \pm 0,01$ & $9,27 \pm 0,01$ & $26,53 \pm 0,01$ \\
$\mathbf{4 0}$ & $25,70 \pm 0,01$ & $19,18 \pm<0,01$ & $30,04 \pm<0,01$ & $20,93 \pm 0,01$ & $30,02 \pm 0,01$ \\
$\mathbf{8 0}$ & $31,78 \pm<0,01$ & $32,87 \pm<0,01$ & $31,84 \pm 0,01$ & $42,22 \pm 0,01$ & $62,74 \pm<0,01$ \\
$\mathbf{1 6 0}$ & $52,24 \pm<0,01$ & $49,09 \pm<0,01$ & $60,11 \pm 0,01$ & $42,87 \pm<0,01$ & $83,95 \pm<0,01$ \\
$\mathbf{3 2 0}$ & $72,78 \pm<0,01$ & $66,77 \pm<0,01$ & $74,50 \pm<0,01$ & $54,06 \pm 0,01$ & $95,92 \pm<0,01$
\end{tabular}




\begin{tabular}{c||ccccc} 
[ $\left.\boldsymbol{\mu g} \cdot \mathbf{m L}^{-\mathbf{1}}\right]$ & AM-Glu & AM-Tyr & AM-Nle & AM-4-n-Phe & Ác. gálico \\
\hline \hline $\mathbf{2 0}$ & $2,21 \pm 0,03$ & $13,54 \pm<0,01$ & $18,80 \pm<0,01$ & $6,62 \pm 0,01$ & $96,52 \pm<0,01$ \\
$\mathbf{4 0}$ & $6,97 \pm 0,01$ & $18,46 \pm<0,01$ & $23,35 \pm 0,02$ & $12,85 \pm<0,01$ & $98,57 \pm<0,01$ \\
$\mathbf{8 0}$ & $11,41 \pm 0,01$ & $29,55 \pm 0,01$ & $31,06 \pm 0,01$ & $20,76 \pm 0,03$ & $98,26 \pm<0,01$ \\
$\mathbf{1 6 0}$ & $26,53 \pm 0,01$ & $43,72 \pm<0,01$ & $47,55 \pm 0,01$ & $29,65 \pm 0,02$ & $97,42 \pm<0,01$ \\
$\mathbf{3 2 0}$ & $44,41 \pm<0,01$ & $61,36 \pm 0,01$ & $64,61 \pm<0,01$ & $51,49 \pm 0,02$ & $95,89 \pm<0,01$
\end{tabular}

Tabela 9: Percentuais de inibição de formação de formazana dos diferentes compostos testados (AM-Glu, AM-Ser, AM-Car, AM-Arg, AM-His, AM-Trp, AM-Tyr, AM-4-n-Phe, AM-Nle e o controle positivo ácido Gálico)de acordo com a concentração final de cada composto em [ $\left.\mu \mathrm{g} \cdot \mathrm{mL}^{-1}\right]$. Dados apresentados como \% de inibição \pm desvio padrão.

Podemos observar na figura 31, que todas as substâncias apresentaram uma significativa atividade contra radicais superóxido, sendo que somente a AMGlu não atingiu a $\mathrm{IC}_{50}$ até a concentração testada, contudo essa concentração será facilmente verificada com a realização de uma nova avaliação com concentrações mais altas, pois apresenta uma forte tendência a elevação. Devemos destacar, o composto AM-His, que obteve um percentual de inibição de formazana maior que $95 \%$ até a concentração mais alta testada, apresentando uma $\mathrm{IC}_{50}$ de $0,204 \mathrm{mM}$, assemelhando-se à substância controle pela intensidade de inibição atingida. Os valores de $\mathrm{IC}_{50}$ dos outros análogos testados foram de 0,204 (AM-Arg), 0,522 (AM-Car), 0,741 (AM-Ser), 0,785 (AM-Tyr), 0,791 (AM-Nle), 0,880 (AM-Trp) e 1,023 (AM-4-n-Phe). O controle, ácido gálico, apresentou valores de inibição muito altos desde as concentrações mais baixas, confirmando a confiança do teste realizado.

O ensaio de determinação do potencial sequestrante de radicais superóxido é uma ferramenta muito útil na avaliação do potencial antioxidante apresentado por determinadas substâncias, pois está diretamente relacionado aos processos antioxidantes que ocorrem nos organismos vivos, uma vez que esta espécie reativa está relacionada a diversas patologias (Oliveira et al., 2009). 


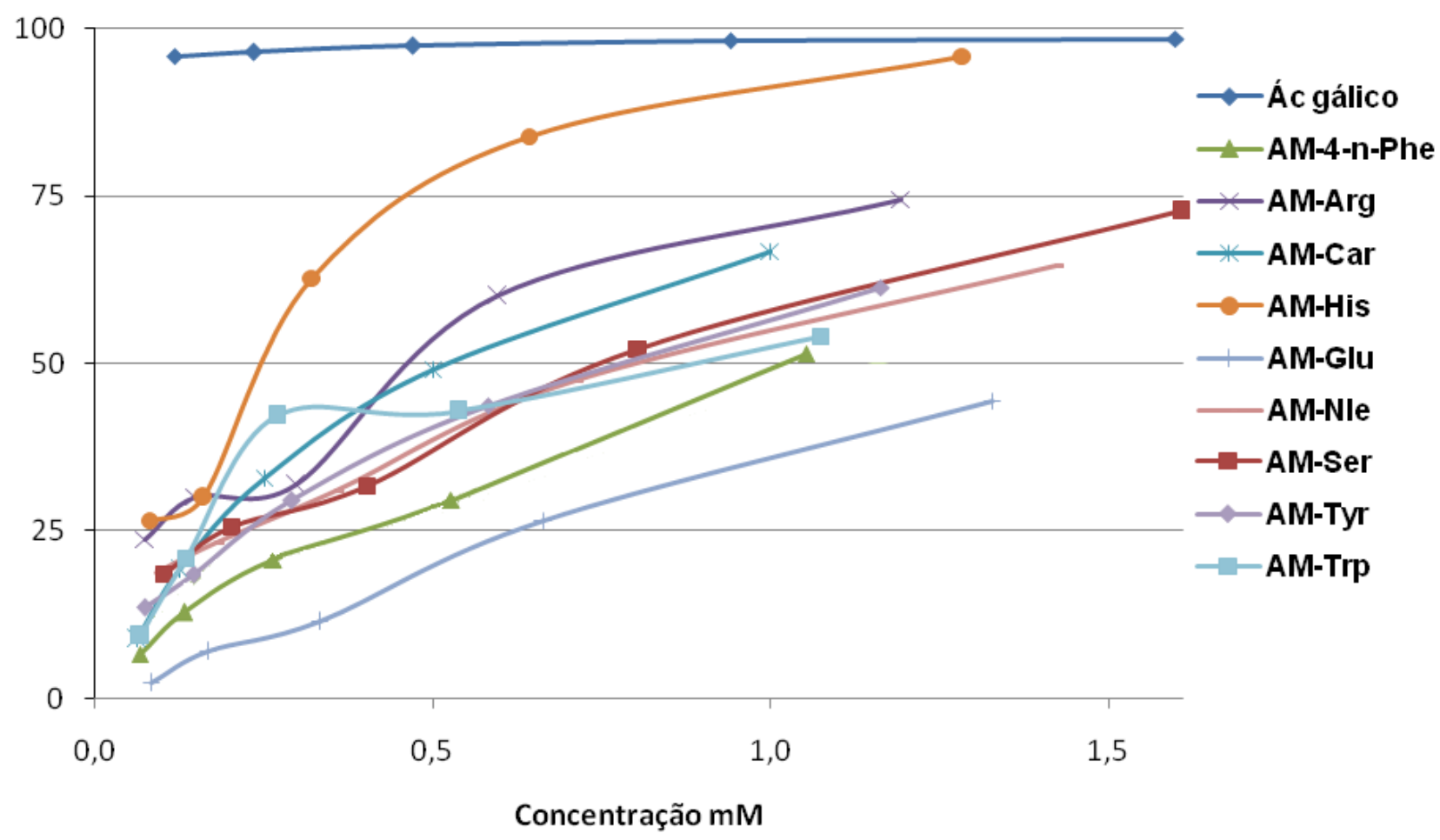

Figura 31: Dados de porcentagem de inibição da formação de formazana pelos compostos, AM-Glu, AM-Ser, AM-Car, AM-Arg, AM-His, AM-Trp, AM-Tyr, AM-4-n-Phe, AM-Nle e o controle positivo ácido Gálico. Dados relacionando percentual de inibição no eixo Y com concentração utilizada no eixo X.

Uma das vantagens da técnica é a estrita correlação com a possível atividade clínica das substâncias antioxidantes. Em contrapartida, temos uma maior dificuldade na execução desta técnica em comparação a outras metodologias, já que o radical formado não possui uma estabilidade muito grande(Kumaran e Karunakaran, 2006; Samak et al., 2009).

Diferentemente do que acontece com as micosporinas em geral, os análogos sintéticos apresentaram uma atividade antioxidante marcante, fato que foi verificado apenas com algumas variáveis de micosporinas, como a micosporina-glicina e a micosporina-taurina (Yakovleva et al., 2004; Obermüller et al., 2005), pois a grande maioria dos componentes dessa classe não apresenta tal propriedade. 


\subsubsection{Avaliação do Potencial Citotóxico}

Após o período de incubação de 24 horas com os compostos e a substância controle, solubilizados no meio de cultura, as células tiveram sua viabilidade avaliada pela metodologia do MTT. Esse composto, que possui uma coloração amarelada, entra nas células e é reduzido pelas enzimas redutases mitocondriais à formazana, resultando em uma coloração violeta intensa, que pode ser mensurado espectrometricamente em $490 \mathrm{~nm}$. Nas células mortas, ou inviáveis, esta redução obviamente não ocorre. Portanto a intensidade da coloração é diretamente proporcional a concentração de células viáveis no meio.

$\mathrm{Na}$ avaliação da figura 32, podemos observar que nenhuma das substâncias testadas resultou em $50 \%$ de morte dos fibroblastos expostos a elas, até a concentração mais alta testada $(1,1 \mathrm{mg} / \mathrm{mL})$. Portanto não foi possível obter a $\mathrm{IC}_{50}$ das mesmas.

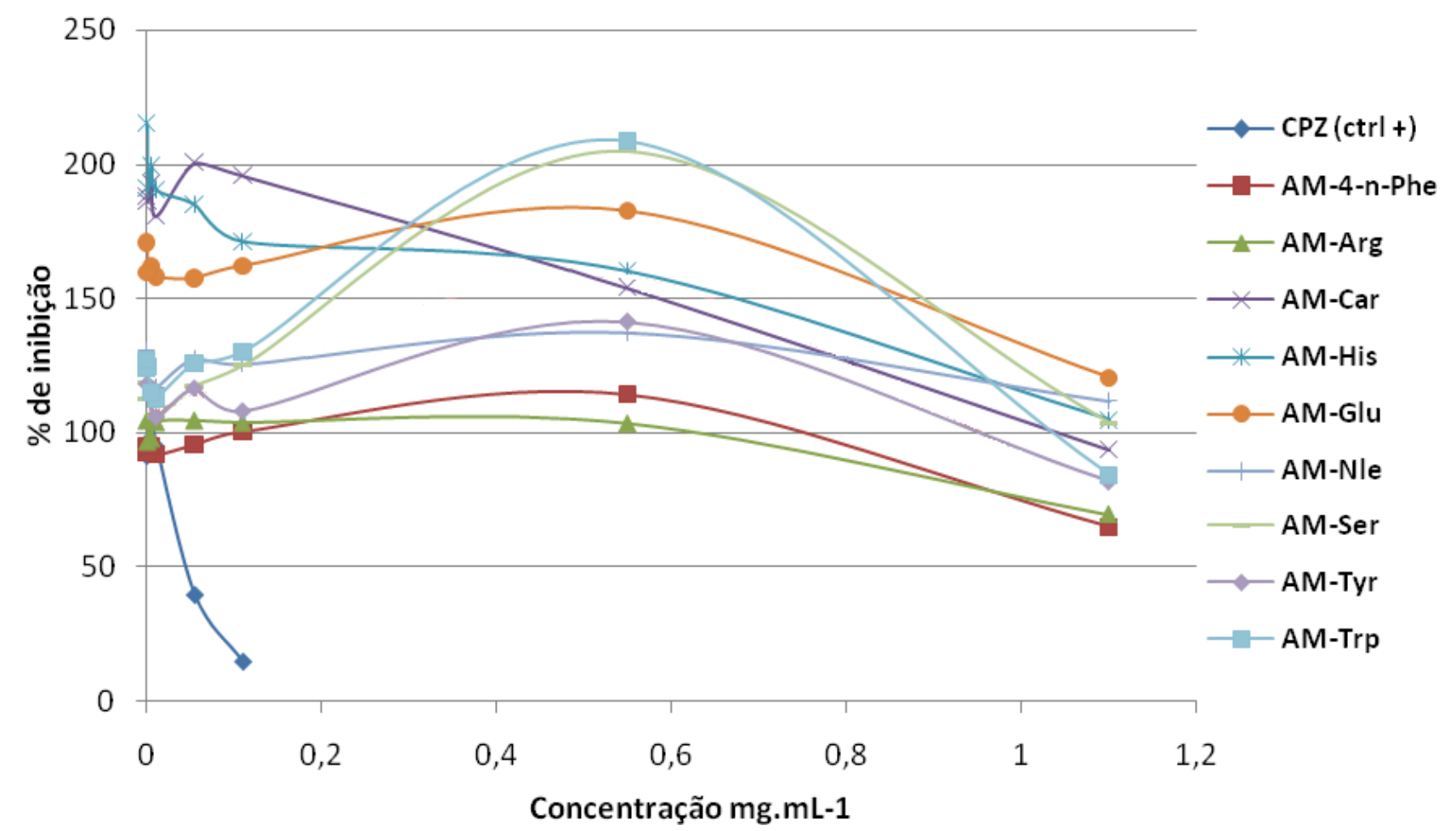

Figura 32: Dados de inibição da viabilidade celular, de fibroblastos expostos à diferentes concentrações das substâncias testadas e do padrão clorpromazina. Dados relacionando percentual de inibição no eixo das ordenadas versus concentração utilizada no eixo das abscissas. 
Contraditoriamente, na avaliação das substâncias testadas, a concentração de fibroblastos aumentou com exposição a todas as substâncias, sendo que algumas populações celulares chegaram a atingir níveis duas vezes mais altos em comparação as populações que não foram expostas, como pode ser observado nas curvas das substâncias AM-Car e AM-His nas concentrações mais baixas testadas e as substâncias AM-Ser e AM-Trp na concentração de $0,55 \mathrm{mg} / \mathrm{mL}$. A partir deste ponto, podemos observar um decréscimo em todas as populações expostas. Este fato pode ser explicado por duas hipóteses distintas: a primeira considera o fato de que como as substâncias avaliadas contêm aminoácidos em sua estrutura, elas podem ter servido como suplemento ao catabolismo celular antes de atingir uma concentração relativamente tóxica (Aujard e Trincal, 1983), ou mesmo essa assimilação dos aminoácidos, acarretar um desequilíbrio metabólico tendendo aos efeitos benéficos quando em comparação aos efeitos tóxicos desencadeados pelas substâncias, até determinada concentração (Klevecz, 1971; Dabrowski et al., 2003), que variou dependendo do aminoácido ligado à 1,3-ciclohexanodiona. A segunda hipótese, leva em conta o fato de ter sido utilizada uma metodologia de avaliação da função mitocondrial das células, que poderia estar exacerbada pela presença das substâncias testadas. 
Figura 33: Fotografia de culturas celulares de fibroblastos em aumento de 100x. Cultura A: Sem exposição a agentes químicos, com $100 \%$ das células viáveis, e cultura B: exposição a clorpromazina, restando um pequeno percentual de células viáveis.

$\mathrm{Na}$ avaliação do controle positivo, a substância CPZ, foi observado o rápido decréscimo das populações expostas a baixas concentrações, sendo obtido uma $I_{50}$ de $0,04 \mathrm{mg} / \mathrm{mL}$ para este composto, e não sendo possível obter um nível máximo de morte celular, já que as populações continuavam decaindo até a maior concentração testada. Estes resultados confirmam que o teste foi válido na avaliação da citotoxicidade. Na figura 33, são demonstradas duas condições testadas, que evidenciam visualmente a ação de uma substância com potencial tóxico para esta linhagem celular.

\subsubsection{Avaliação do Potencial Fototóxico}

$\mathrm{Na}$ avaliação do potencial fototóxico, os compostos foram incubados juntamente as células por 50 minutos, com exposição concomitante à incidência de radiação UVA, a uma irradiância de $1,7 \mathrm{~mW} / \mathrm{cm}^{2}$, exposição essa considerada a maior incidência de luz não citotóxica. Para essa determinação, foram preparadas 
duas placas idênticas, sendo que uma ficou exposta a radiação enquanto a outra ficou incubada no escuro.

$\mathrm{Na}$ análise da figura gerada a partir de crescentes concentrações dos compostos e controle, a qual as células foram expostas, podemos observar a toxicidade decorrente da exposição à substância controle clorpromazina, que obteve uma $I_{50}$ na placa não exposta a radiação (- IRR) semelhante à observada no ensaio de citotoxicidade, de $0,04 \mathrm{mg} / \mathrm{mL}$. Porém, quando foi introduzida ao meio de cultura no qual as células estavam, juntamente a exposição a radiação (+ IRR) teve seus efeito tóxico potencializado, obtendo uma $I C_{50}$ de $0,0023 \mathrm{mg} / \mathrm{mL}$. Calculando-se a razão das $I_{50}$ do grupo - IRR pelo + IRR, obtemos um valor de PIF igual a 16,6, fato que confirma a autenticidade do teste, já que testes realizados anteriormente, descreviam o PIF da CPZ como maior que 14,4 (Spielmann et al., 1998; OECD, 2004).

\section{+ IRR}

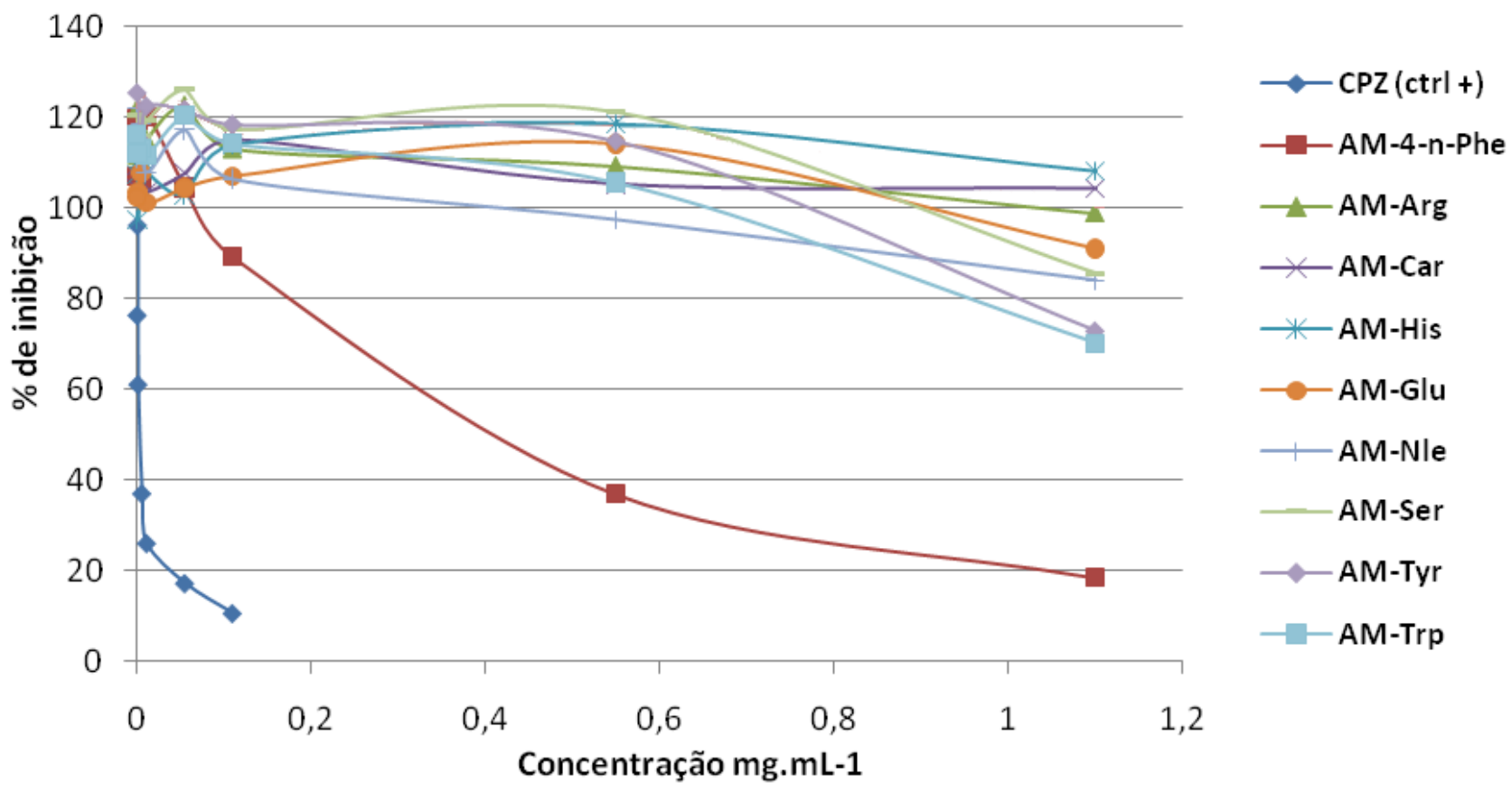

Figura 34: Curvas das substâncias e o controle CPZ, submetidos a exposição a radiação UVA. Dados relacionando percentual de inibição no eixo das ordenadas versus concentração utilizada no eixo das abscissas. 
Dentre as substâncias avaliadas, somente uma apresentou potencial tóxico, quando ativada pela exposição à radiação. A substância ácido 2-(4nitrofenil)-2-(3-oxociclohexilideneamino) acético (7) decorrente da reação que envolveu o aminoácido 4-nitro-fenilalanina e a 1,3-ciclohexanodiona, obteve um índice de mortalidade celular de $80 \%$ na concentração mais alta testada com exposição concomitante à radiação, apresentando um $I_{50}$ de $0,04 \mathrm{mg} / \mathrm{mL}$. Contudo, na concentração mais alta testada, de $1,1 \mathrm{mg} / \mathrm{mL}$, quase todas as substâncias testadas apresentavam uma tendência a diminuição da população celular exposta a elas.

- IRR
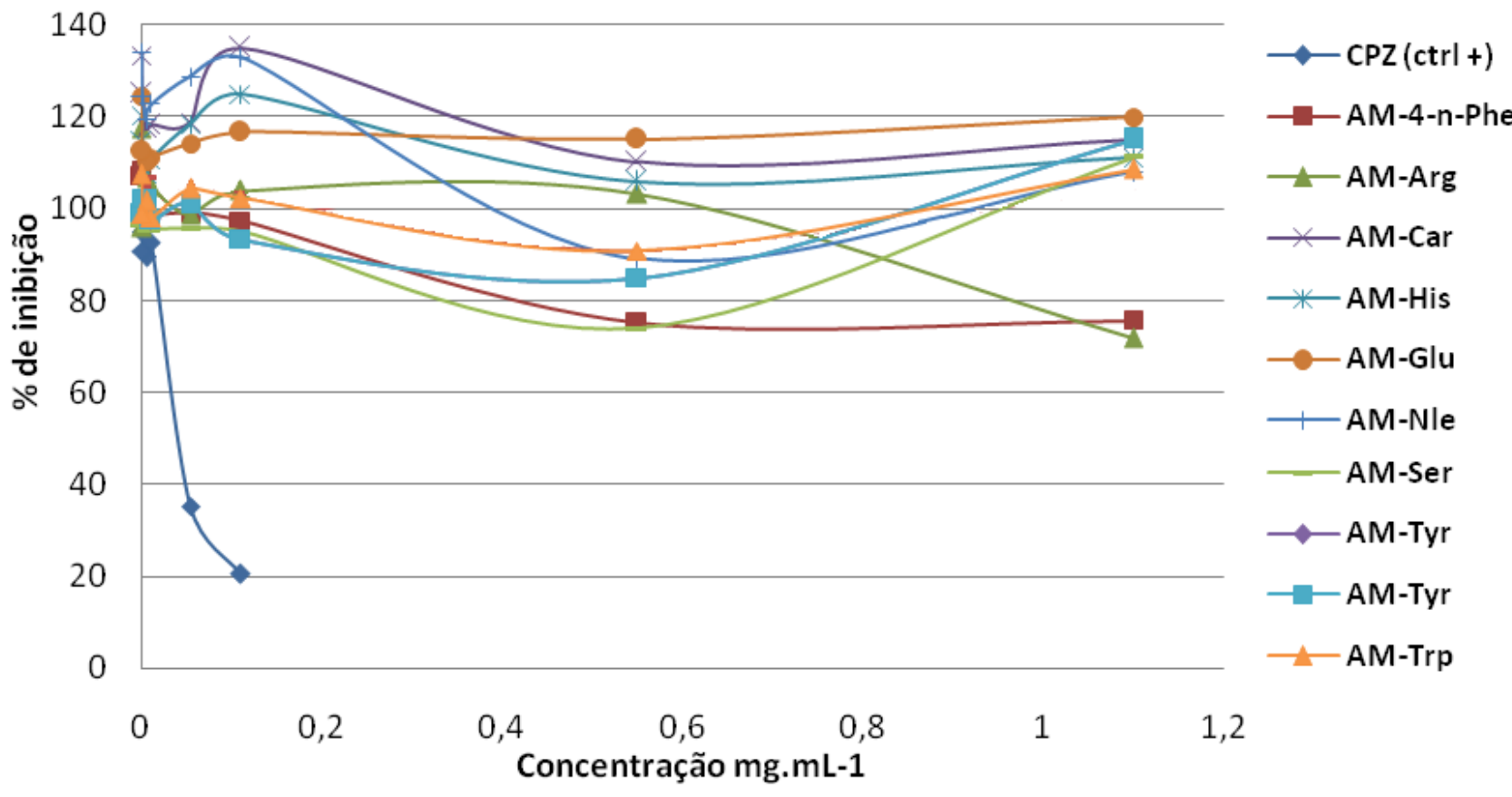

Figura 35: Curvas das substâncias e o controle CPZ, sem exposição a radiação UVA. Dados relacionando percentual de inibição no eixo das ordenadas versus concentração utilizada no eixo das abscissas.

Como não foi obtida uma $\mathrm{IC}_{50}$ da $4-n-F$, na placa que não foi exposta a radiação, procedeu-se o cálculo da determinação de >PIF, que determina a razão da máxima concentração testada pela $\mathrm{IC}_{50}$ da placa irradiada, onde obtemos um valor de 2,75, considerado como fototóxico pela agência européia OECD (OECD, 
2004). O fato de somente este composto apresentar ação fototóxica, pode estar ligado ao fato de que altas doses de compostos que possuem uma cadeia nitro incorporado, podem reduzir a ação de diversas enzimas do metabolismo ou mesmo inibir a formação das mesmas, ocasionando a morte celular por apoptose, como foi descrito em outras linhagens celulares (Egan et al., 1997) (Aujard e Trincal, 1983) 
6. CONCLUSÃO 
$\Rightarrow$ As metodologias sintéticas propostas baseadas em princípios de química verde foram efetivas na obtenção dos análogos.

$\Rightarrow \quad$ Nenhuma das metodologias sintéticas testadas pode ser apresentada como melhor para a obtenção dos análogos, visto que foram obtidos diferentes rendimentos de acordo com cada reação; contudo, as três metodologias apresentaram resultados satisfatórios.

$\Rightarrow$ As substâncias obtidas apresentaram espectros característicos de absorção da radiação, atuando principalmente na região do UVB, porém, não possuem a particularidade de absorver grandes quantidades de energia, sendo necessária a incorporação de outros grupamentos funcionais à molécula a fim de aumentar a conjugação da mesma e o seu potencial fotoprotetor.

$\Rightarrow$ As substâncias obtidas apresentaram atividade antioxidante classificadas de moderada a acentuada, de acordo com as metodologias avaliadas.

$\Rightarrow$ Nenhuma das substâncias obtidas apresentou potencial citotóxico quando presentes em culturas celulares de fibroblastos.

$\Rightarrow \quad$ Uma das substâncias obtidas, resultante da reação entre 1,3ciclohexanodiona e 4-nitro-fenilalanina, apresentou potencial fototóxico quando presentes em cultura celular de fibroblastos com exposição concomitante a radiação UVA. 


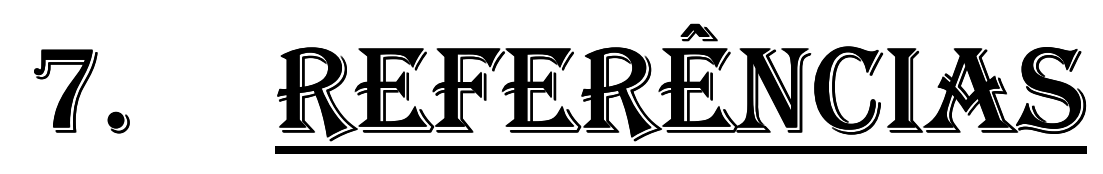


ANANTHASWAMY, H. N., LOUGHLIN, S. M., et al. Sunlight and skin cancer: Inhibition of p53 mutations in UV-irradiated mouse skin by sunscreens. Nature Medicine, v.3, n.5, p.5. 1997.

ARAÚJO, L. R. G. D., CAVALCANTE JR., C. L., et al. Synthesis of cubic Y zeolite using a pulsed microwave heating system. Materials Research, v.2, p.105-109. 1999.

AUJARD, C. e TRINCAL, G. The effects of N-methyl-N'-nitro-N-nitrosoguanidine on KB cells. I. Growth inhibition and cell killing in relation to inhibition of macromolecular synthesis. Chemico-Biological Interactions, v.44, n.1-2, p.79-93. 1983.

BANASZAK, A. T., LAJEUNESSE, T. C., et al. The synthesis of mycosporine-like amino acids (MAAs) by cultured, symbiotic dinoflagellates. Journal of Experimental Marine Biology and Ecology, v.249, n.2, p.219-233. 2000.

BANDARANAYAKE, W. M. Mycosporines: are they nature's sunscreens? Natural Product Report, v.15, n.2, p.159-72. 1998.

BASKETTER, D. A., CHAMBERLAIN, M., et al. The classification of skin irritants by human patch test. Food and Chemical Toxicology, v.35, n.8, p.845-852. 1997.

BOLSOVER, S. R., HYAMS, J. S., et al. Cell Biology. Hoboken: Wiley-Liss, v.2. 2004 (A short course)

BORGES, S. D. S. e KORN, M. Geração sonoquímica de oxidantes em solução aquosa saturada de tetracloreto de carbono. Química nova, v.25, p.558-562. 2002.

BOSCOLO, O. H., MENDONÇA-FILHO, R. F. W., et al. Potencial antioxidante de algumas plantas de restinga citadas como medicinais. Revista Brasileira de Plantas Medicinais, v.9, n.1, p.8-12. 2007.

BRAND-WILLIAMS, W., CUVELIER, M. E., et al. Use of a free radical method to evaluate antioxidant activity. LWT - Food Science and Technology, v.28, n.1, p.25-30. 1995.

CADENAS, E. Biochemistry of Oxygen Toxicity. Annual Review of Biochemistry, v.58, n.1, p.79-110. 1989.

CALDWELL, M. M., ROBBERECHT, R., et al. Internal filters: Prospects for UV-acclimation in higher plants. Physiologia Plantarum, v.58, n.3, p.445-450. 1983.

CARDOZO, K. H. M. Estudos de compostos fotoprotetores da radiação ultravioleta em algas: aminoácidos tipo micosporinas (MAAs). Instituto de Química, Universidade de São Paulo, São Paulo, 2007. 173 p. 
CARDOZO, K. H. M., GUARATINI, T., et al. Metabolites from algae with economical impact. Comparative Biochemistry and Physiology Part C: Toxicology \& Pharmacology, v.146, n.1-2, 2007/8//, p.60-78. 2007.

CARDOZO, K. H. M., VESSECCHI, R., et al. A theoretical and mass spectrometry study of the fragmentation of mycosporine-like amino acids. International Journal of Mass Spectrometry, v.273, n.1-2, p.11-19. 2008.

CARROLL, A. K. e SHICK, J. M. Dietary accumulation of UV-absorbing mycosporine-like amino acids (MAAs) by the green sea urchin (Strongylocentrotus droebachiensis). Marine Biology, v.124, n.4, p.9. 1996.

CLARK, J. H. Green Chemistry: Challenges and opportunities. Green Chemistry, v.1, n.1, p.1 - 8. 1999.

CONDE, F. R., CARIGNAN, M. O., et al. In Vitro cis-trans Photoisomerization of Palythene and Usujirene. Implications on the In Vivo Transformation of Mycosporine-like Amino Acids. Photochemistry and Photobiology, v.77, n.2, p.146-150. 2003.

CONDE, F. R., CHURIO, M. S., et al. The photoprotector mechanism of mycosporine-like amino acids. Excited-state properties and photostability of porphyra-334 in aqueous solution. Journal of Photochemistry and Photobiology B: Biology, v.56, n.2-3, p.139-144. 2000.

COTRAN, R. S., KUMAR, V., et al. Robbins Patologia Estrutural e Funcional. Rio de Janeiro: Guanabara Koogan S. A., v.6. 2000

CRUZ, A. S., FIGUEIREDO, C. A., et al. Comparação de métodos para testar a citotoxicidade "in vitro" de materiais biocompatíveis. Revista de Saúde Pública, v.32, p.153-159. 1998.

CRUZ, A. S., FIGUEIREDO, C. A., et al. Detecção da citotoxicidade de materiais biocompatíveis nas linhagens celulares MRC-5, HeLa e RC-IAL. Revista do Instituto de Medicina Tropical de São Paulo, v.34, p.99-105. 1992.

DABROWSKI, K., GUDERLEY, H., et al. Intermediary Metabolism. In: (Ed.). Fish Nutrition (Third Edition). San Diego: Academic Press, 2003. Intermediary Metabolism, p.309-365

DENG, J., CHENG, W., et al. A novel antioxidant activity index (AAU) for natural products using the DPPH assay. Food Chemistry, v.In Press, Corrected Proof. 2010.

DIFFEY, B. L. e GRICE, J. The influence of sunscreen type on photoprotection. British Journal of Dermatology, v.137, n.1, p.103-105. 1997. 
DRAIZE, J. H., WOODARD, G., et al. Methods for the study of a irritation and toxicity of substances applied topically to the skin and mucous membranes. The journal of pharmacology and experimental therapeutics, v.82, p.14. 1944.

DROGË, W. Free Radicals in the Physiological Control of Cell Function. Physiol. Rev., v.82, n.1, January 1, 2002, p.47-95. 2002.

DUARTE, J. A. R., APPELL, H. J., et al. Endothelium-Derived Oxidative Stress May Contribute to Exercise-Induced Muscle Damage. International journal of sports medicine, v.14, n.08, p.440-443. 1993.

DUNLAP, W. C., CHALKER, B. E., et al. Nature's sunscreen from the Great Barrier Reef, Australia. International Journal of Cosmetic Science, v.20, n.1, p.41-51. 1998.

DUNLAP, W. C., MASAKI, K., et al. A novel antioxidant derived from seaweed. In: (Ed.). Recent Developments in Marine Biotechnology. New York: Plenun Press, 1998. A novel antioxidant derived from seaweed, p.33-35

DUNLAP, W. C. e YAMAMOTO, Y. Small-molecule antioxidants in marine organisms: antioxidant activity of mycosporine-glycine. Comparative Biochemistry and Physiology, B: Biochemistry and Molecular Biology, v.112, n.1, p.10. 1995.

DUPUIS, G. e BENEZRA, C. Allergic contact dermatitis to simple chemicals. New York: M. Dekker, v.2. 1982. 183 p. (A Molecular Approach)

EGAN, D., JAMES, P., et al. Studies on the cytostatic and cytotoxic effects and mode of action of 8-nitro-7-hydroxycoumarin. Cancer Letters, v.118, n.2, p.201-211. 1997.

EPSTEIN, J. H. Phototoxicity and photoallergy. Seminars in Cutaneous Medicine and Surgery, v.18, n.4, p.274-284. 1999.

FAVRE-BONVIN, J. e ARPIN, N. Structure de la mycosporine (P310). Canadian Journal of Chemistry, v.54, n.7, p.9. 1976.

FENSTER, C. P., WEINSIER, R. L., et al. Obesity, Aerobic Exercise, and Vascular Disease: The Role of Oxidant Stress. Obesity, v.10, n.9, p.964-968. 2002.

FERRERES, F., SOUSA, C., et al. Chemical composition and antioxidant activity of Tronchuda cabbage internal leaves. European Food Research and Technology, v.222, n.1, p.88-98. 2006.

FLOR, J., DAVOLOS, M. R., et al. Protetores Solares. Química nova, v.30, n.1, p.6. 2007.

FRANKLIN, L. A. e FORSTER, R. M. The changing irradiance environment: consequences for marine macrophyte physiology, productivity and ecology. European Journal of Phycology, v.32, n.3, p.207 - 232. 1997. 
GASPARRO, F. P., MITCHNICK, M., et al. A Review of Sunscreen Safety and Efficacy. Photochemistry and Photobiology, v.68, n.3, p.243-256. 1998.

GEDYE, R., SMITH, F., et al. The use of microwave ovens for rapid organic synthesis. Tetrahedron Letters, v.27, n.3, p.279-282. 1986.

GIGUERE, R. J., BRAY, T. L., et al. Application of commercial microwave ovens to organic synthesis. Tetrahedron Letters, v.27, n.41, p.4945-4948. 1986.

GOLDFARB, A. H. Antioxidants: role of supplementation to prevent exercise-induced oxidative stress. Medicine and science in sports and exercise, v.25, n.2, p.232 - 6. 1993.

GONG, C. e HART, D. P. Ultrasound induced cavitation and sonochemical yields. The Journal of the Acoustical Society of America, v.104, n.5, p.2675-2682. 1998.

GONTIJO, G. T., PUGLIESI, M. C. C., et al. Fotoproteção. Surgical \& Cosmetic Dermatology, v.1, n.4, p.186 - 192. 2009.

GRAEBIN, C. S. e EIFLER-LIMA, V. L. O uso do forno de microondas na síntese orgânica em fase sólida. Química nova, v.28, p.73-76. 2005.

GROTTO, D., VALENTINI, J., et al. Avaliação da estabilidade do marcador plasmático do estresse oxidativo: malondialdeído. Química nova, v.31, p.275-279. 2008.

GUZMÁN, S., GATO, A., et al. Antiinflammatory, analgesic and free radical scavenging activities of the marine microalgae Chlorella stigmatophora and Phaeodactylum tricornutum. Phytotherapy Research, v.15, n.3, p.224-230. 2001.

HALLIWELL, B. e GUTTERIDGE, J. M. C. Free redicals in biology and medicine. Oxford: Oxford University Press. 1999. 936 p.

HE, Y.-Y., KLISCH, M., et al. Adaptation of Cyanobacteria to UV-B Stress Correlated with Oxidative Stress and Oxidative Damage. Photochemistry and Photobiology, v.76, n.2, p.188-196. 2002.

SEER training modules Skin Cancer Anatomy. NATIONAL INSTITUTE of HEALTH, National Cancer Institute. acessado em: 15/08/2010 <http://training.seer.cancer.gov/>.

HOYER, K., KARSTEN, U., et al. Photoprotective substances in Antarctic macroalgae and their variation with respect to depth distribution, different tissues and developmental stages. Marine Ecology Progress Series, v.211, p.13. 2001.

HUGGETT, A. C., SCHILTER, B., et al. Comparative methods of toxicity testing : Consensus document following an international life sciences institute-ILSI europe workshop held in May 1995. Food and Chemical Toxicology, v.34, n.2, p.183-192. 1996. 
JAIMES, G., CASTRO, C. D., et al. Principio activo citotoxico de Espeletia killipii Cuatr. sobre células tumorales y su toxicidad frente a células normales humanas. Revista Brasileira de Farmacognosia, v.16, p.140-145. 2006.

JORDAN, B. R. e CALLOW, J. A. The Effects of Ultraviolet-B Radiation on Plants: A Molecular Perspective. In: (Ed.). Advances in Botanical Research: Academic Press, v.Volume 22, 1996. The Effects of Ultraviolet-B Radiation on Plants: A Molecular Perspective, p.97-162

JUNQUEIRA, L. C. e CARNEIRO, J. Histologia Básica. Rio de Janeiro: Guanabara Koogan S. A., v.11. 2008

KERR, J. B. e MCELROY, C. T. Evidence for Large Upward Trends of Ultraviolet-B Radiation Linked to Ozone Depletion. Science, v.262, n.5136, November 12, 1993, p.1032-1034. 1993.

KEYNES, R. G. e GARTHWAITE, J. Nitric oxide and its role in ischaemic brain injury. Curr Mol Med, v.4, n.2, Mar, p.179-91. 2004.

KING, J. F., RATHORE, R., et al. pH optimization of nucleophilic reactions in water. Journal of the American Chemical Society, v.114, n.8, p.3028-3033. 1992.

KLEVECZ, R. R. Rapid protein catabolism in mammalian cells is obscured by reutilization of amino acids. Biochemical and Biophysical Research Communications, v.43, n.1, p.7681. 1971.

$\mathrm{KLISCH}, \mathrm{M}$. e HÄDER, D.-P. Mycosporine-like amino acids in the marine dinoflagellate Gyrodinium dorsum: induction by ultraviolet irradiation. Journal of Photochemistry and Photobiology B: Biology, v.55, n.2-3, p.178-182. 2000.

KUMARAN, A. e KARUNAKARAN, R. Antioxidant and free radical scavenging activity of an aqueous extract of Coleus aromaticus. Food Chemistry, v.97, n.1, p.109-114. 2006.

LENARDÃO, E. J., FREITAG, R. A., et al. "Green chemistry": os 12 princípios da química verde e sua inserção nas atividades de ensino e pesquisa. Química nova, v.26, p.123129. 2003.

LI, Z., ZHU, A., et al. Silica-supported dichlorophosphate: a recoverable cyclodehydrant for the eco-friendly synthesis of 2,5-disubstituted 1,3,4-oxadiazoles under solvent-free and microwave irradiation conditions. Journal of the Brazilian Chemical Society, v.19, p.1622-1626. 2008.

LODISH, H., BERK, A., et al. Molecular Cell Biology: W. H. Freeman \& Co., v.6. 2008

LOPES, A. C. e GRAFF, S. Fundamentos de toxicologia clínica. São Paulo: Atheneu. 2006 
LORCA, B. S. S., VOLPATO, N. M., et al. Análise "in vitro" e "in vitro" do potencial irritante de tensoativos derivados de aminoácidos. Revista Analytica, v.32, p.80-83. 2008.

LUBINEAU, A., AUGÉ, J., et al. Water-Promoted Organic Reactions. Synthesis, v.1994, n.08, p.741-760. 1994.

LÜHKEN, A. e BADER, H. J.Energy input from microwaves and ultrasound - examples of new approaches to green chemistry.London UK.Royal Society os Chemistry.2002. disponível em:

<http://www.rsc.org/education/teachers/learnnet/green/docs/microwaves.pdf>.

MANAHAN, S. E. Fundamentals of Environmental chemistry. Florence - KY: CRC Press, v.3. 2008. $1048 \mathrm{p}$.

MARTINEZ, A. E. T., SILVÉRIO, K. G., et al. Efeito da nicotina na viabilidade e morfologia de fibroblastos: estudo in vitro. Pesquisa Odontológica Brasileira, v.16, p.234-238. 2002.

MARTINS, M. A. P., CUNICO, W., et al. Ultrasound promoted synthesis of 5-hydroxy-5trihalomethyl-4,5-dihydroisoxazoles and [beta]-enamino trihalomethyl ketones in water. Ultrasonics Sonochemistry, v.13, n.4, p.364-370. 2006.

MARTINS, M. A. P., PEREIRA, C. M. P., et al. Microwave-assisted synthesis of 5trichloromethyl substituted 1-phenyl-1H-pyrazoles and 1,2-dimethylpyrazolium chlorides. Tetrahedron Letters, v.44, n.35, p.6669-6672. 2003.

MAYER, A. M. S. e GUSTAFSON, K. R. Marine pharmacology in 2005-2006: Antitumour and cytotoxic compounds. European Journal of Cancer, v.44, n.16, p.2357-2387. 2008.

MAYER, A. M. S. e HAMANN, M. T. Marine Pharmacology in 2000: Marine Compounds with Antibacterial, Anticoagulant, Antifungal, Anti-inflammatory, Antimalarial, Antiplatelet, Antituberculosis, and Antiviral Activities; Affecting the Cardiovascular, Immune, and Nervous Systems and Other Miscellaneous Mechanisms of Action. Marine Biotechnology, v.6, n.1, p.37-52. 2004.

MCKENZIE, R., CONNOR, B., et al. Increased Summertime UV Radiation in New Zealand in Response to Ozone Loss. Science, v.285, n.5434, September 10, 1999, p.1709-1711. 1999.

MEDINA, J., DE BRUGEROLLE DE FRAISSINETTE, A., et al. Use of Human Skin Equivalent Apligraf for in Vitro Assessment of Cumulative Skin Irritation Potential of Topical Products. Toxicology and Applied Pharmacology, v.164, n.1, p.38-45. 2000.

MOLYNEUX, P. The use of the stable free radical diphenylpicryl-hydrazil (DPPH) for estimating antioxidant activity. Songklanakarin Journal of Science and Technology, v.26, n.2, p.9. 2004. 
MORAES, E. D. C. F., SZNELWAR, R. B., et al. Manual de Toxicologia Analítica. São Paulo: Roca. 1991

MOSMANN, T. Rapid colorimetric assay for cellular growth and survival: Application to proliferation and cytotoxicity assays. Journal of Immunological Methods, v.65, n.1-2, p.55-63. 1983.

MTURI, G. J. e MARTINCIGH, B. S. Photostability of the sunscreening agent 4-tert-butyl4'-methoxydibenzoylmethane (avobenzone) in solvents of different polarity and proticity. Journal of Photochemistry and Photobiology A: Chemistry, v.200, n.2-3, p.410420. 2008.

NAKAMURA, H., KOBAYASHI, J. I., et al. Separation of mycosporine-like amino acids in marine organisms using reversed-phase high-performance liquid chromatography. Journal of Chromatography A, v.250, p.113-118. 1982.

NANDURKAR, N. S., PATIL, D. S., et al. Ultrasound assisted synthesis of metal-1,3diketonates. Inorganic Chemistry Communications, v.11, n.7, p.733-736. 2008.

NATHALIE, D., YANNICK, G., et al. Assessment of the phototoxic hazard of some essential oils using modified $3 T 3$ neutral red uptake assay. Toxicology in Vitro, v.20, n.4, p.480489. 2006.

NAZEERUDDIN, M. K., BESSHO, T., et al. A high molar extinction coefficient charge transfer sensitizer and its application in dye-sensitized solar cell. Journal of Photochemistry and Photobiology A: Chemistry, v.185, n.2-3, p.331-337. 2007.

NAZEMIYEH, H., DELAZAR, A., et al. Free radical scavengers from the aerial parts of Grammosciadium platycarpum Boiss. \& Hausskn. (Apiaceae) and GC-MS analysis of the essential oils from its fruits. Revista Brasileira de Farmacognosia, v.19, p.914-918. 2009.

NEALE, P. J., BANASZAK, A. T., et al. Ultraviolet sunscreens in Gymnodinium Sanguineum (Dinophyceae): Mycosporines-like amino acids protect against inhibition of photosynthesis. Journal of Phycology, v.34, n.6, p.928-938. 1998.

OBERMÜLLER, B., KARSTEN, U., et al. Response of oxidative stress parameters and sunscreening compounds in Arctic amphipods during experimental exposure to maximal natural UVB radiation. Journal of Experimental Marine Biology and Ecology, v.323, n.2, p.100-117. 2005.

OBERMULLER, B., KARSTEN, U., et al. Effects of UV-radiation on oxidative stress parameters in polar marine amphipods, and the role of UV-absorbing mycosporine-like amino acids (MAAs) in their diet. Antarctic Biology in a Global Context, Proceedings, p.63-68

338. 2003. 
OECD. OECD Guidelines for Testing of Chemicals Test No. 432. In Vitro 3T3 NRU phototoxicity test: 15 p. 2004.

OGA, S. Fundamentos de Toxicologia. São Paulo: Atheneu. 2008

OLIVEIRA, I., COELHO, V., et al. Scavenging capacity of strawberry tree (Arbutus unedo L.) leaves on free radicals. Food and Chemical Toxicology, v.47, n.7, p.1507-1511. 2009.

OSTERWALDER, U., LUTHER, H., et al. Novo protetor UVA. Cosmetic \& toiletries, v.12, p.7. 2000.

PAOLA, M. V. R. V. D., RIBEIRO, M. E., et al. Multifuncionalidade das vitaminas. $\underline{\text { Cosmetic }}$ \& toiletries, v.10. 1998.

PARK, S. M. e KIM, B. H. Ultrasound-triggered water gelation with a modified nucleoside. Soft Matter, v.4, n.10, p.1995-1997. 2008.

PELLATI, F., BENVENUTI, S., et al. Analysis of phenolic compounds and radical scavenging activity of Echinacea spp. Journal of Pharmaceutical and Biomedical Analysis, v.35, n.2, p.289-301. 2004.

POINERN, G. E., BRUNDAVANAM, R. K., et al. Synthesis and characterisation of nanohydroxyapatite using an ultrasound assisted method. Ultrasonics Sonochemistry, v.16, n.4, p.469-474. 2009.

QU, G.-R., WU, J., et al. Synthesis of novel 6-[N,N-bis(2-hydroxyethyl)amino]purine nucleosides under microwave irradiation in neat water. Green Chemistry, v.11, n.6, p.760-762. 2009.

QUIROGA, B. D. Brown fat thermogenesis and exercise: two examples of physiological oxidative stress? Free Radical Biology and Medicine, v.13, n.4, p.325 - 40. 1992.

RAIHAN, M. J., KAVALA, V., et al. 'On-water' synthesis of chromeno-isoxazoles mediated by [hydroxy(tosyloxy)iodo]benzene (HTIB). Green Chemistry, p.-. 2010.

RAMOS, M. F. S., SANTOS, E. P., et al. Avaliação fototóxica e screening mutagênico de extratos de propolis, Aloe spp. e Hamamelis virginiana. Revista de Ciências Farmacêuticas Básica e Aplicada, v.26, n.2, p.7. 2005.

ROGERS, J. V. e MCDOUGAL, J. N. Improved method for in vitro assessment of dermal toxicity for volatile organic chemicals. Toxicology Letters, v.135, n.1-2, p.125-135. 2002.

ROY, C. R., GIES, H. P., et al. The solar UV radiation environment: measurement techniques and results. Journal of Photochemistry and Photobiology B: Biology, v.31, n.1-2, p.21-27. 1995. 
SAMAK, G., SHENOY, R. P., et al. Superoxide and hydroxyl radical scavenging actions of botanical extracts of Wagatea spicata. Food Chemistry, v.115, n.2, p.631-634. 2009.

SANSEVERINO, A. M. Síntese orgânica limpa. Química nova, v.23, p.102-107. 2000.

SANSEVERINO, A. M. Microondas em síntese orgânica. Química nova, v.25, p.660-667. 2002.

SCHUELLER, R. e ROMANOWSKI, P. Introdução aos produtos fotoprotetores. Cosmetic \& toiletries, v.12, n.4, p.60 - 67. 2000.

SHELDON, R. A., ARENDS, I., et al. Green Chemistry and catalysis. Weinhein: Wiley-VCH. 2007. $434 \mathrm{p}$.

SHICK, J. M. e DUNLAP, W. C. Mycosporine-like amino acids and related gadusols: Biosynthesis, Accumulation, and UV-Protective Functions in Aquatic Organisms. Annual Review of Physiology, v.64, n.1, p.223-262. 2002.

SIGNORINI, J. L. Atividade física e radicais livres: Aspectos biológicos, químicos, fisiopatológicos e preventivos. São Paulo: Ícone. 1993. 160 p.

SILVA, F. M. D., LACERDA, P. S. B. D., et al. Desenvolvimento sustentável e química verde. Química nova, v.28, p.103-110. 2005.

SINGH, N. B., SINGH, R. J., et al. Organic solid state reactivity. Tetrahedron, v.50, n.22, p.6441-6493. 1994.

SINGH, S. e SINGH, J. Dermal toxicity: effect of jet propellant-8 fuel exposure on the biophysical, macroscopic and microscopic properties of porcine skin. Environmental Toxicology and Pharmacology, v.10, n.3, p.123-131. 2001.

SINHA, R. P., KLISCH, M., et al. Mycosporine-like amino acids in the marine red alga Gracilaria cornea - effects of UV and heat. Environmental and Experimental Botany, v.43, n.1, p.33-43. 2000.

SINHA, R. P., SINGH, S. P., et al. Database on mycosporines and mycosporine-like amino acids (MAAs) in fungi, cyanobacteria, macroalgae, phytoplankton and animals. Journal of Photochemistry and Photobiology B: Biology, v.89, n.1, p.29-35. 2007.

SPIELMANN, H., BALLS, M., et al. The International EU/COLIPA In Vitro Phototoxicity Validation Study: Results of Phase II (Blind Trial). Part 1: The 3T3 NRU Phototoxicity Test. Toxicology in Vitro, v.12, n.3, p.305-327. 1998.

STAPLETON, A. E. Ultraviolet Radiation and Plants: Burning Questions. Plant Cell, v.4, n.11, November 1, 1992, p.1353-1358. 1992. 
STEINER, D. Discromias - parte I: Generalidades. Cosmetic \& toiletries, v.10. 1995.

STREILEIN, J. W., TAYLOR, J. R., et al. Immune surveillance and sunlight-induced skin cancer. Immunology Today, v.15, n.4, p.174-179. 1994.

SUSLICK, K. S. Sonochemistry. Science, v.247, p.1439-1445. 1990.

SUSLICK, K. S. Sonoluminescence and Sonochemistry. In: M. R. A. (Ed.). Encyclopedia of Physical Science and Technology. San Diego: Academic Press, Inc., v.3, 2001. Sonoluminescence and Sonochemistry, p.22

TAYLOR, C. R., STERN, R. S., et al. Photoaging/photodamage and photoprotection. Journal of the American Academy of Dermatology, v.22, n.1, p.1-15. 1990.

THOMAS, M. Ultraviolet and visible spectroscopy. New York: Wiley. 2000

TODA, F. Solid State Organic Chemistry: Efficient Reactions, Remarkable Yields, and Stereoselectivity. Accounts of Chemical Research, v.28, n.12, p.480-486. 1995.

TORRES, E. M. M. A necessidade de redução de geração de resíduos nos processos de fabricação. Revista de Química Industrial, v.64, n.704, p.12 - 4. 1996.

TYRRELL, R. M. e PIDOUX, M. Action Spectra for Human Skin Cells: Estimates of the Relative Cytotoxicity of the Middle Ultraviolet, Near Ultraviolet, and Violet Regions of Sunlight on Epidermal Keratinocytes. Cancer Research, v.47, n.7, April 1, 1987, p.18251829. 1987.

VALADARES, M. C., CASTRO, N. C. D., et al. Synadenium umbellatum: citotoxicidade e danos ao DNA de células da medula óssea de camundongos. Revista Brasileira de Ciências Farmacêuticas, v.43, p.631-638. 2007.

VANCINI, R. L., LIRA, C. A. B. D., et al. Radicais livres, estresse oxidativo e exercício. Universidade Federal de São Paulo. São Paulo. 2005

VELLOSA, J. C. R., BARBOSA, V. D. F., et al. Profile of Maytenus aquifolium action over free radicals and reactive oxygen species. Revista Brasileira de Ciências Farmacêuticas, v.43, p.447-453. 2007.

WILKINSON, S. L. "Green" is practical, even profitable. No longer a luxury, green chemistry becomes a central strategy for sustainable firms. Chemical \& Engineering news, v.75, p.35 - 43. 1997.

XIN, X., WANG, Y., et al. A facile and efficient one-pot synthesis of polysubstituted benzenes in guanidinium ionic liquids. Green Chemistry, v.12, n.5, p.893-898. 2010. 
XIONG, F., KOPECKY, J., et al. The occurrence of UV-B absorbing mycosporine-like amino acids in freshwater and terrestrial microalgae (Chlorophyta). Aquatic Botany, v.63, n.1, p.37-49. 1999.

YAKOVLEVA, I., BHAGOOLI, R., et al. Differential susceptibility to oxidative stress of two scleractinian corals: antioxidant functioning of mycosporine-glycine. Comparative Biochemistry and Physiology Part B: Biochemistry and Molecular Biology, v.139, n.4, p.721-730. 2004.

YOKOZAWA, T., CHEN, C. P., et al. Study on the Inhibitory Effect of Tannins and Flavonoids against the 1,1-Diphenyl-2-picrylhydrazyl Radical. Biochemical Pharmacology, v.56, n.2, p.213-222. 1998.

YU, J.-J., WANG, L.-M., et al. Synthesis of tetraketones in water and under catalyst-free conditions. Green Chemistry, v.12, p.4. 2010.

ZIEGLER, A., JONASON, A. S., et al. Sunburn and p53 in the onset of skin cancer. Nature, v.372, p.4. 1994. 